\title{
Archaeology of rock art at Dalakngalarr 1, central-western Arnhem Land
}

\author{
Daniel James, Bruno David, Jean-Jacques Delannoy, Robert Gunn, \\ Alexandria Hunt, Ian Moffat, Nadia lacono, Sean Paul Stephens \\ and Margaret Katherine
}

\section{Introduction}

In 2011, we began researching the subsurface archaeology, geomorphology and rock art of Dalakngalarr 1, a moderately sized rockshelter on top of the central-western Arnhem Land plateau in Jawoyn Country. Here, four lines of evidence give relative or absolute ages for rock art:

1. Archaeological excavations adjacent to a boulder that contains a painting of a red macropod reveal when that boulder attained its present position, so the red macropod must have been painted sometime afterwards.

2. Paintings of axe/hoes with metal heads indicate that they were painted during the Europeancontact period. A nearby group of X-ray images are painted in comparable pigments, suggesting that they are contemporaneous with the axe/hoes.

3. Geomorphological evidence suggests that parts of the site's ceiling collapsed at datable times in the past, indicating that the art on that roof must post-date the roof collapse.

4. Direct accelerator mass spectrometry (AMS) radiocarbon dates on beeswax art.

\section{Archaeological context}

Dalakngalarr 1 is an enclosed shelter, located deep in Jawoyn Country on the central-western Arnhem Land plateau, some $190 \mathrm{~km}$ southeast of Darwin (Figures 13.1 and 13.2; see also Figure 1.1). It was rediscovered in 2007 as part of the Jawoyn Rock Art and Heritage Project (Gunn and Whear 2007). Dalakngalarr 1 is part of a large, low-lying outcrop of Kombolgie sandstone that dips down towards the southeast. 


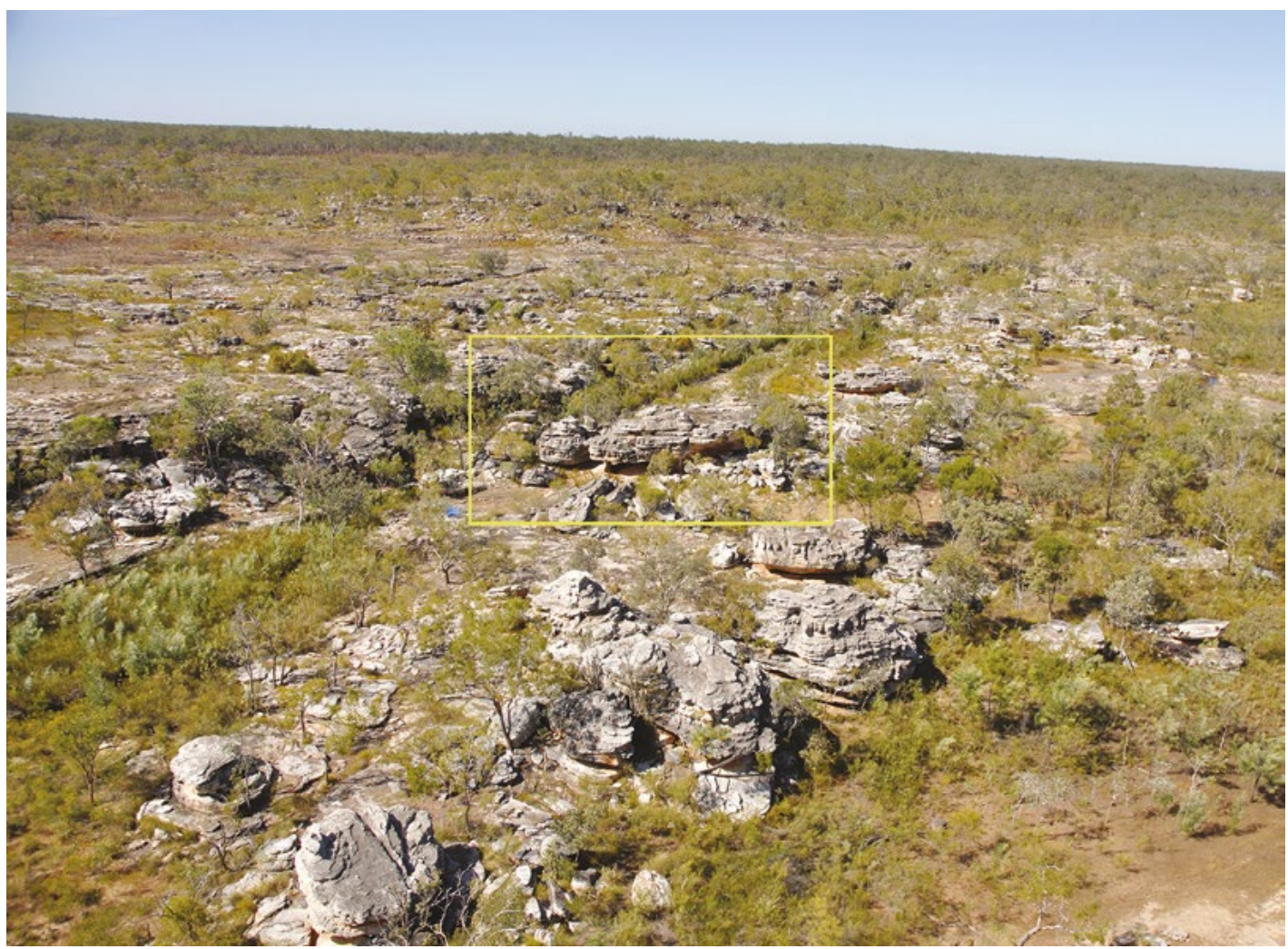

Figure 13.1 Dalakngalarr site complex, looking southeast. Yellow rectangle locates Dalakngalarr 1.

Source: Photograph by Daniel James.

The rock outcrops in the vicinity of Dalakngalarr 1 contain three adjacent complexes of archaeological sites: Dalakngalarr (allocated the code ARN-082 in the Jawoyn site database), LBX (ARN-083) and Dalakjarang (ARN-102). These three site complexes are separated by seasonal streams that flow along eroded joint lines in the bedrock. Each site complex is located in a distinct geomorphological setting and contains a locally major art and occupation site.

The three site complexes each contain distinctive archaeological sites (Tables 13.1 and 13.2). The landscape of Dalakjarang is of a long, low rock ridge within which are found a number of small shelters. The Dalakjarang site complex fronts a flat sand plain with a large expanse of flat rock to the southeast above and behind the rockshelters. This site complex contains a large linear stone arrangement, an unusually high number of standing stones (cf. Gunn et al. 2012) and a large and hitherto unique painted motif in its major shelter. Two sets of grinding patches occur on bedrock surfaces between the major site and the nearby creek. The large stone arrangement was interpreted by Margaret Katherine as a ceremonial site that was probably related to the regional Dalak (sand goanna, Varanus panoptes) Dreaming. This stone arrangement lies directly in front of the major art shelter that, in addition to housing the unusual motif mentioned above, also contains almost two-thirds of all the art within the site complex. Another unusual aspect of the rock art here is the high number of sites (10 of 23 art shelters) with 'Dynamic Figures' (cf. Chaloupka 1993:106-119). 

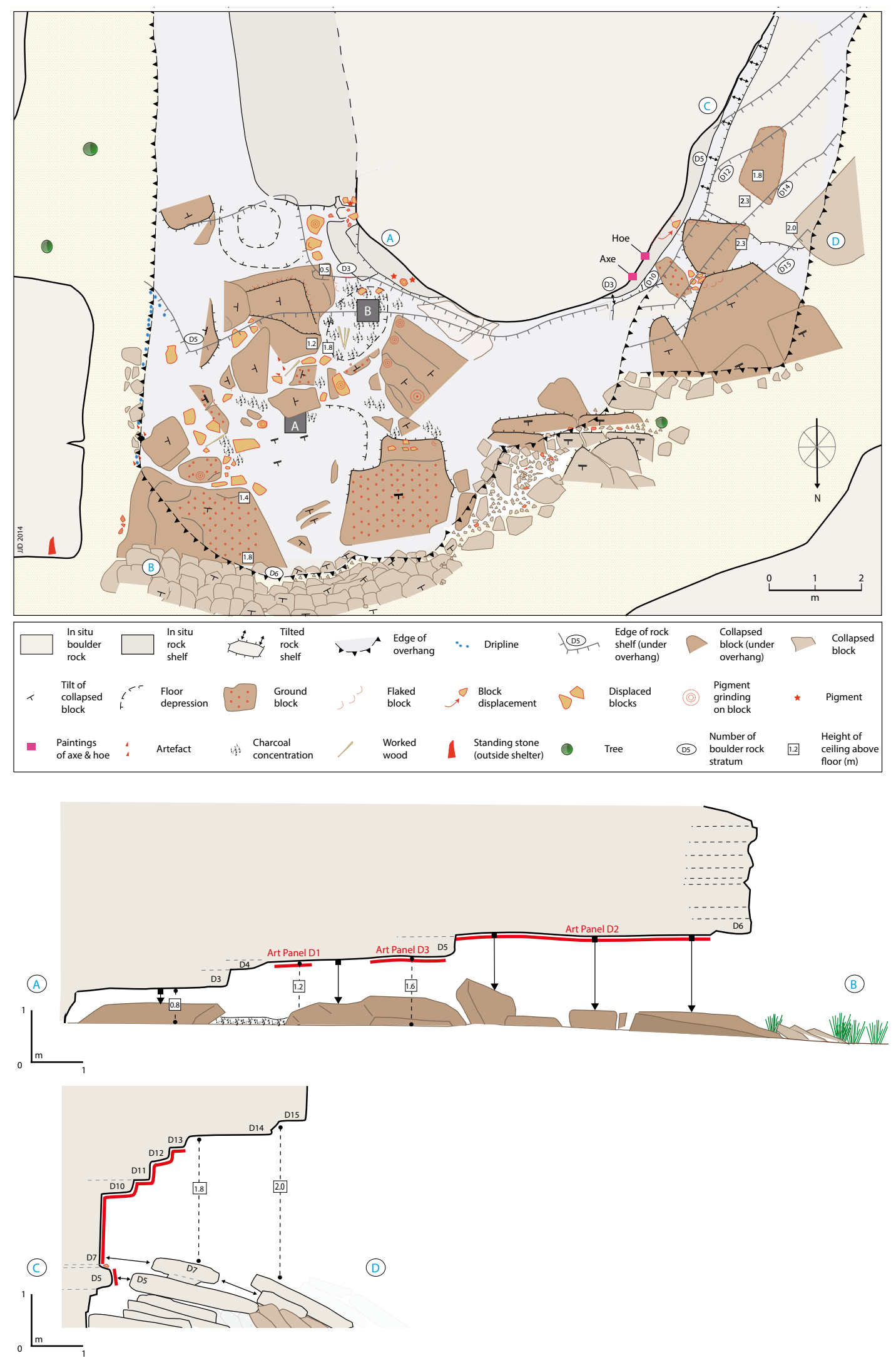

Figure 13.2 Plan and cross-sections of Dalakngalarr 1 showing location of rock art panels.

Source: Illustration by Jean-Jacques Delannoy. 
In contrast to that of Dalakjarang, the landscape of Dalakngalarr consists of a tumble of residual sandstone ridges and collapsed blocks. As with Dalakjarang, most of the artwork in this site complex is concentrated within one shelter (Dalakngalarr 1), but here, and throughout the site complex, the emphasis is on paintings of fauna with a much greater use of white pigment. A large number of 'older' red and yellow paintings occur within this site complex, but no classic Dynamic Figures have been located. Also, while another stone arrangement occurs here, it is much smaller and within a more confined space than that at Dalakjarang.

At site complex LBX, a small cluster of residual stacks stand in front of a solid outcrop of bedrock cut by a grid of narrow, joint-derived corridors (cf. Young et al. 2009:172). Here, most rockshelters occur at the corners of intersecting corridors. The artwork is focused on the larger ARN-083/1 shelter; however, it has only around one-third of the artworks in the complex, so the concentration at this one site is notably less than in the dominant site at the other two site complexes. At LBX, the art is predominantly older red and yellow art, with an emphasis on smaller paintings of fauna. No archaeological traces other than art shelters have been recorded here.

Neither archaeological excavations nor detailed art recording have yet been undertaken within either the Dalakjarang or LBX site complexes.

Table 13.1 Contents of site complexes.

\begin{tabular}{|l|c|c|c|c|c|c|}
\hline Site complex & Area $\mathbf{( m )}$ & $\begin{array}{c}\text { \# of art } \\
\text { sites }\end{array}$ & $\begin{array}{c}\text { \# of images } \\
\text { (estimated) }\end{array}$ & $\begin{array}{c}\text { Standing } \\
\text { stones }\end{array}$ & $\begin{array}{c}\text { Stone } \\
\text { arrangements }\end{array}$ & $\begin{array}{c}\text { Grinding } \\
\text { areas }\end{array}$ \\
\hline Dalakjarang (ARN-102) & $850 \times 450$ & 23 & 699 & 28 & 7 & 2 \\
\hline Dalakngalarr (ARN-082) & $200 \times 30$ & 9 & 887 & 3 & 1 & \\
\hline LBX (ARN-083) & $350 \times 200$ & 7 & 408 & & & \\
\hline
\end{tabular}

Source: Authors' data.

Table 13.2 Number of rock art images at the major site of each site complex.

\begin{tabular}{|l|l|c|}
\hline Site complex & Major site & \# of images \\
\hline Dalakjarang (ARN-102) & ARN-102/3 & 435 \\
\hline Dalakngalarr (ARN-082) & Dalakngalarr 1 (ARN-082/1) & 502 \\
\hline LBX (ARN-083) & ARN-083/1 & 134 \\
\hline
\end{tabular}

Source: Authors' data.

\section{Dalakngalarr 1}

During initial examination by Robert Gunn and Leigh Douglas in September 2007, Dalakngalarr 1 was seen to contain a high number of paintings for such an enclosed shelter, estimated at $>400$ visible images (Table 13.2). These images were thought to cover a broad span of time, with slim anthropomorphs holding boomerangs (cf. Lewis 1988) being of considerable age evident on the eastern and western outer walls, and demonstrably more recent art of the European-contact period in the form of two paintings of metal axe/hoes on the rear interior wall of the shelter. The more recent X-ray art appeared to have been painted in a strikingly similar style, and with similar pigments, to that at Nawarla Gabarnmang some $17 \mathrm{~km}$ to the west-southwest. This initial impression of similarity in style and composition of the fish paintings at the two sites prompts questions about connections between them, a topic of investigation currently being addressed by James (in prep.) and Gunn (Chapter 12). Dalakngalarr 1 was chosen for study because of its abundant rock art, and because its overhang houses the largest rockshelter of the site complex. 


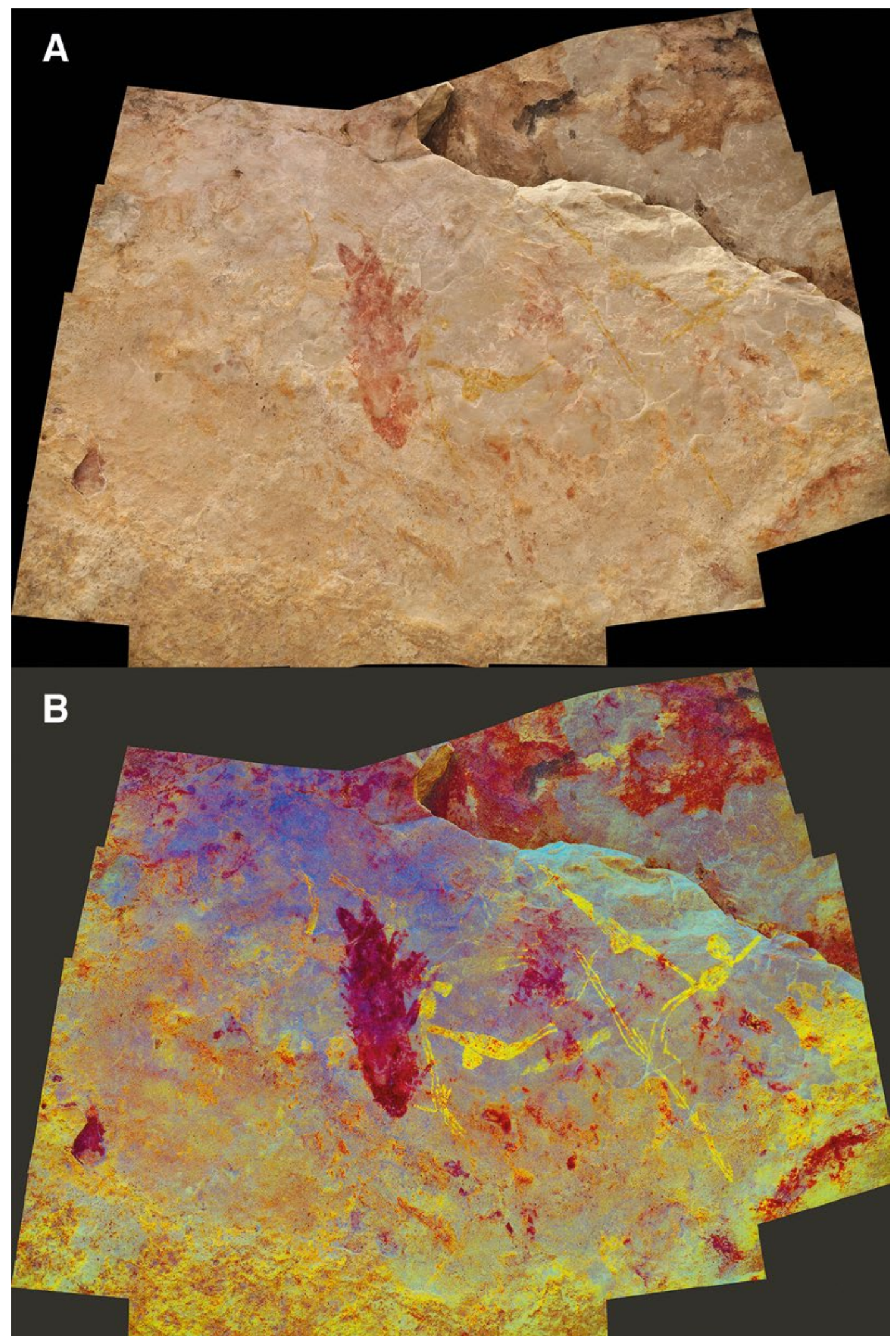

Figure 13.3 Faded, ancient rock art of Panel A5 on eastern wall of Dalakngalarr 1.

A: Original photograph. B: Digitally enhanced photograph using DStretch_Ids10 enhancement. Source: Photograph and enhancement by Daniel James. 
Stylistic and thematic elements, such as the presence of boomerangs that Lewis (1988), Chaloupka (1993) and others have attributed to Dynamic and Post-Dynamic Figures or their equivalents as older phases of rock art, show that the oldest visible art in the shelter occurs along the eastern and western walls. Of particular interest is ceiling Panel A5 with pictures of yellow anthropomorphs holding boomerangs (Figure 13.3). Sub-surface archaeological investigations in this eastern part would be problematic as there is considerable evidence of wet-season water flow over and into the soft sandy soil. The rock surface is also stained black by water flow. This black staining has affected much of the eastern outer wall's rock surface (see Figure 13.4, right-hand side of back wall); it is particularly prevalent in the area around Panel A5, limiting our ability in this part to understand the age of the art. On the opposite side of the site there are no excavatable deposits beneath the western wall's stepped rocky platform.

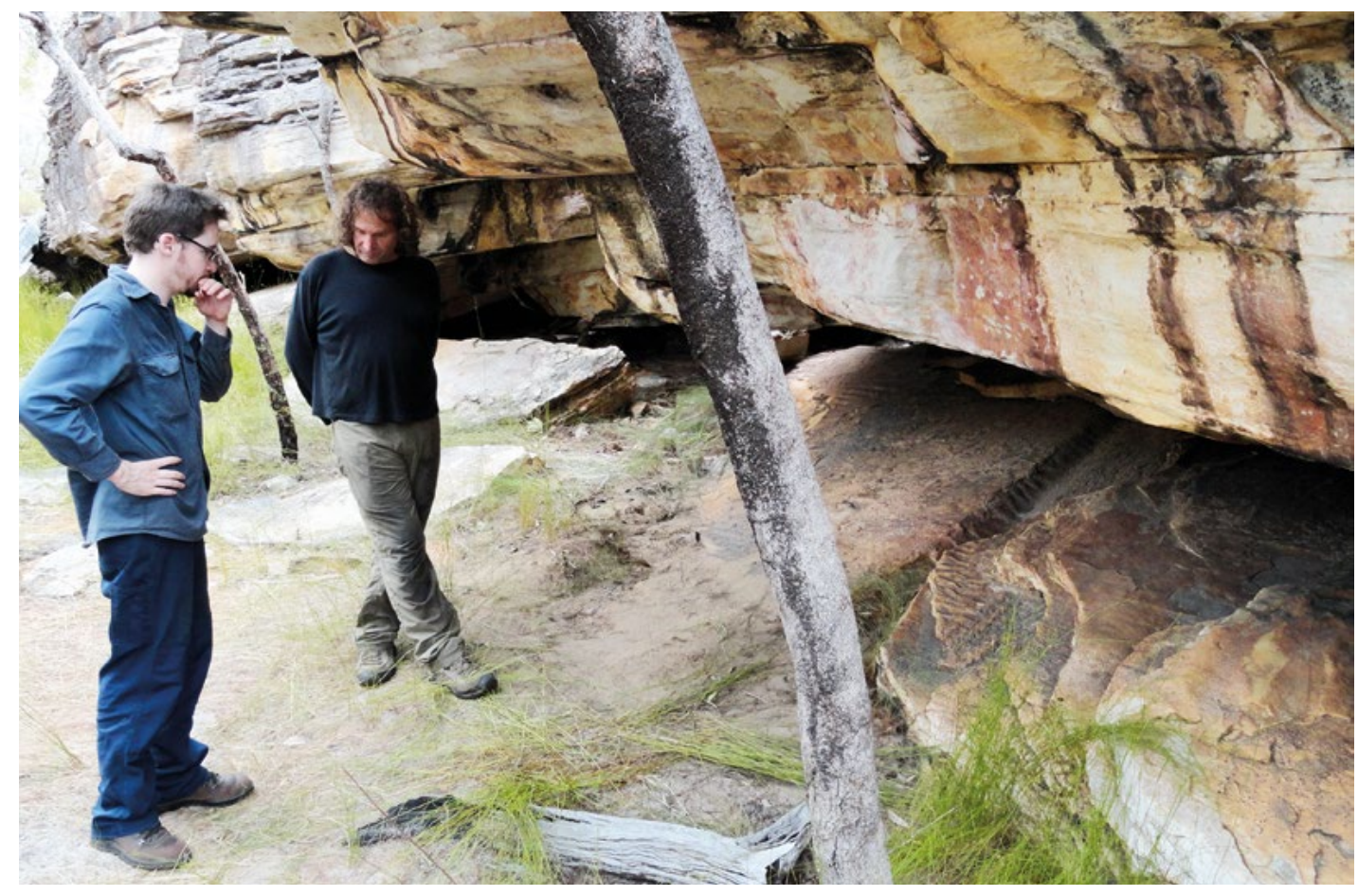

Figure 13.4 Evidence of water flow at ground level and along the eastern wall adjacent to Panel A5. Source: Photograph by Chris Urwin.

Aiming to contextualise the rock art, our choice of where to excavate took into account site formation processes in the broader environment. The present shelter cavity was formed by the collapse of layers of rock near the northern margin of the site. Today, the shelter has a wide, northwesterly to northeasterly aspect (Figure 13.5). The eastern rock face delimiting the edge of the shelter has undergone wall and ceiling collapse, with individual collapsed layers of rock now creating a sloping, rocky floor angled c. $30^{\circ}$ to horizontal (Figures 13.2 and 13.6). Here paintings on the outer rock face are found up to c. 1.0-1.5 $\mathrm{m}$ above ground; they also occur on the ceiling above the sloping rock floor. In contrast, the paintings on the western, outer wall are raised up to c. $4 \mathrm{~m}$ above ground, considerably higher than on the eastern outer wall, with roof and wall collapse forming a rocky shelf that fronts the western outer wall (Figures 13.7 and 13.8). Overhanging layers of rock form a mini-ceiling over some of the western wall, offering some protection from the elements, but overall it is quite exposed. Numerous paintings are found on the western rock face and on this secondary ceiling. 


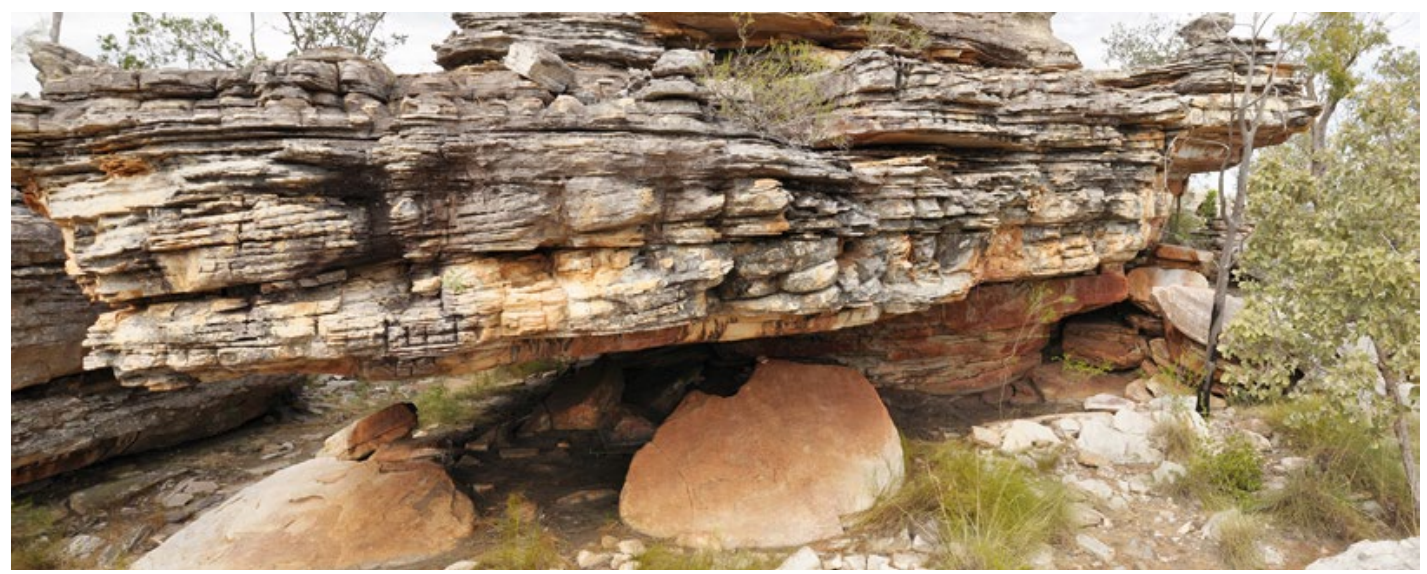

Figure 13.5 Dalakngalarr 1, looking south.

Source: Photograph by Daniel james.

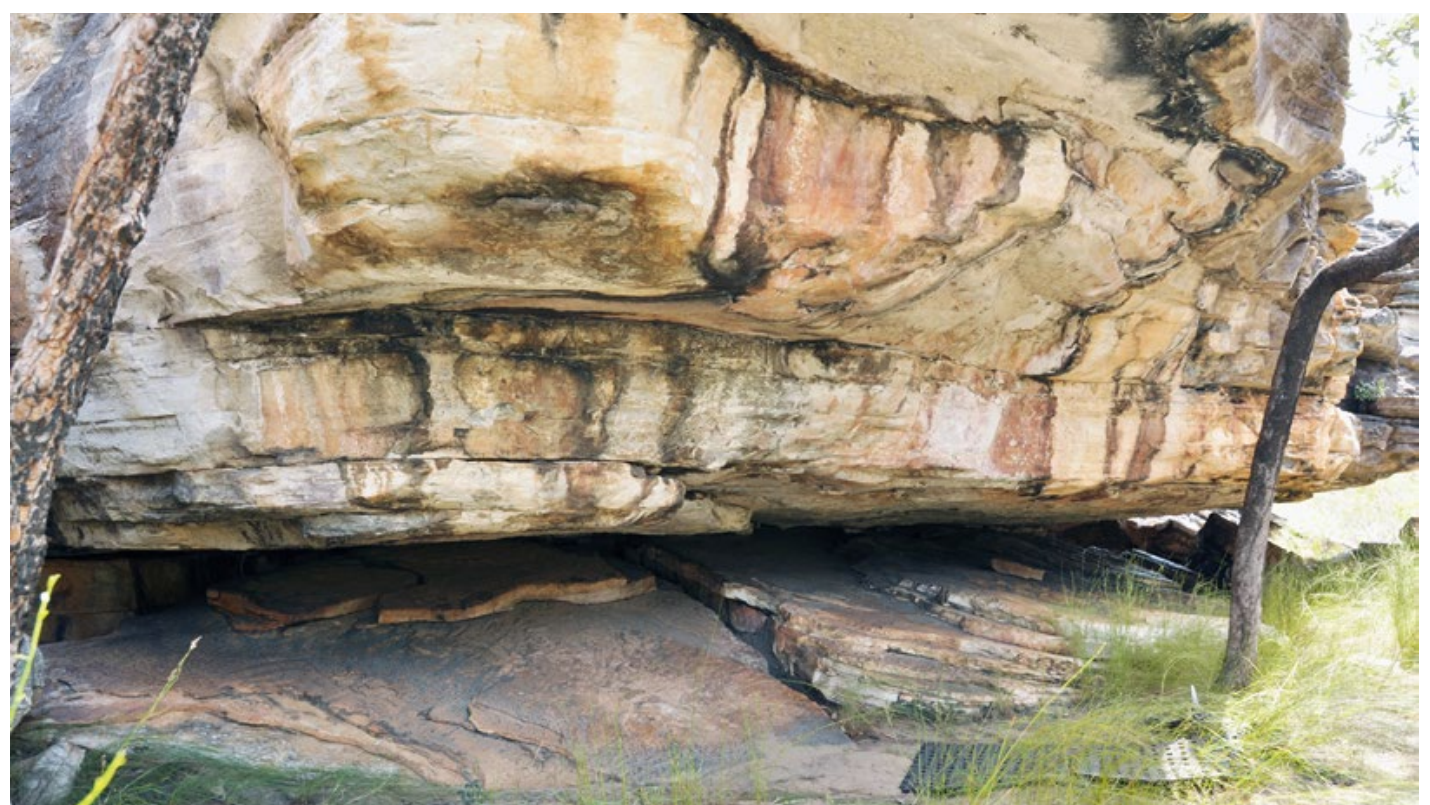

Figure 13.6 Eastern wall showing evidence of ceiling collapse at ground level, looking northwest. Source: Photograph by Daniel James.

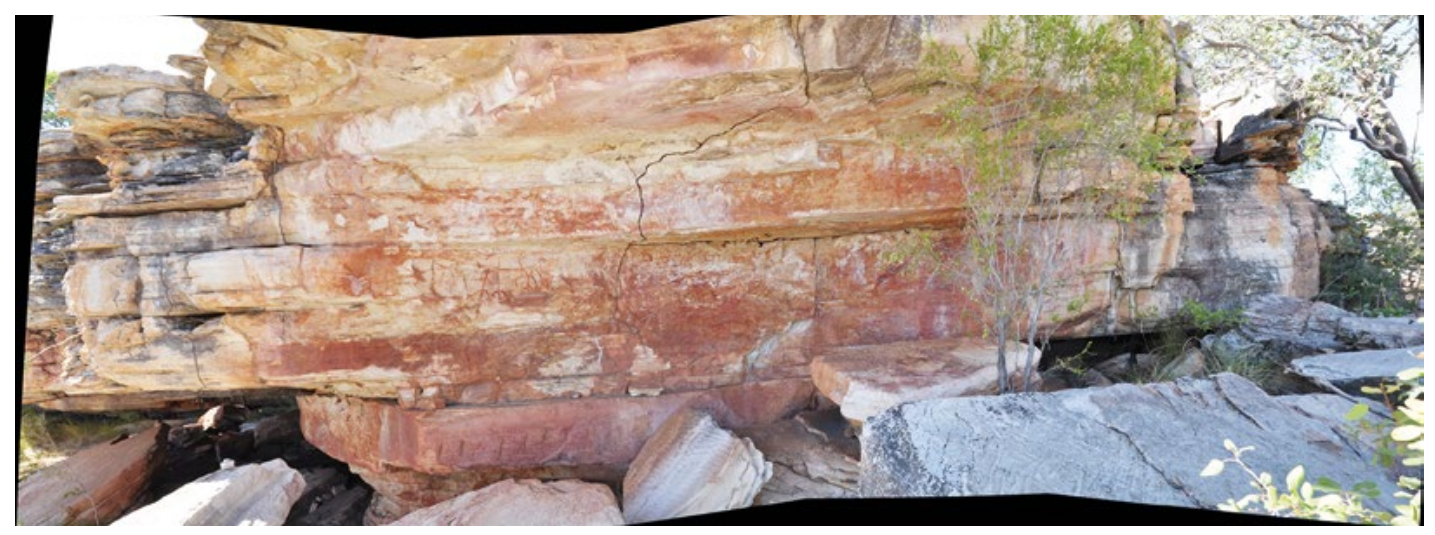

Figure 13.7 Stitched panorama of the western outer wall, looking east-southeast. Source: Photograph by Daniel james. 
Dalakngalarr 1 lies within the coarse-grained and at times pebbly sandstone and quartzite outcrops that occur within the Marlgowa Sandstone unit of the Kombolgie Formation (Ferenczi and Sweet 2004). Many parts of the shelter where finer-grained quartzite is exposed have been heavily quarried for stone tools. There is also evidence of flaking activity on fallen boulders and rock slabs. Many of the rock collapses on the shelter floor have resulted in the creation of surfaces suitable for walking or sitting, and many of these have been worn smooth (Figure 13.8).

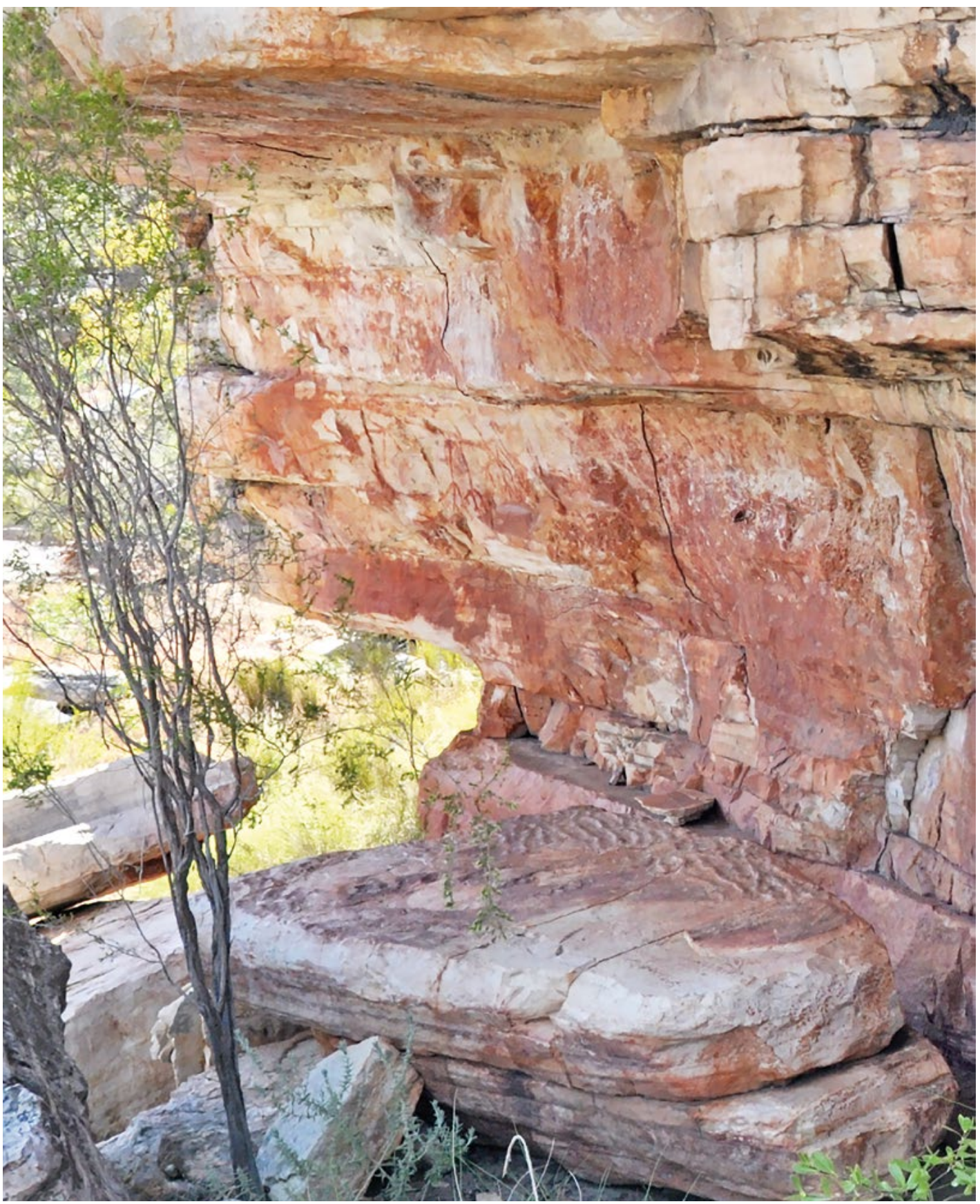

Figure 13.8 Western wall in a part of the site well protected from the elements and cool in the afternoon.

The large slab in the foreground, from the collapsed ceiling, is now elevated above ground level and worn smooth. Source: Photograph by Daniel James. 
In the early dry season months from May to July, the shelter enjoys the following daily rhythm: the easternmost wall is exposed to direct sunlight throughout the morning hours, peaking towards the middle of the day. From around midday onwards, the western wall becomes increasingly exposed to sunlight until c. 5-6 pm when direct light reaches the entire wall. The western wall is more protected from the elements, particularly wind and rain coming from the east to southeast. The shelter interior is generally well protected from conditions affecting both the eastern and western outer walls. As a result, the floor under the overhang is well preserved; it contains rich cultural deposits that have been darkened by fires lit by people (Figure 13.9).

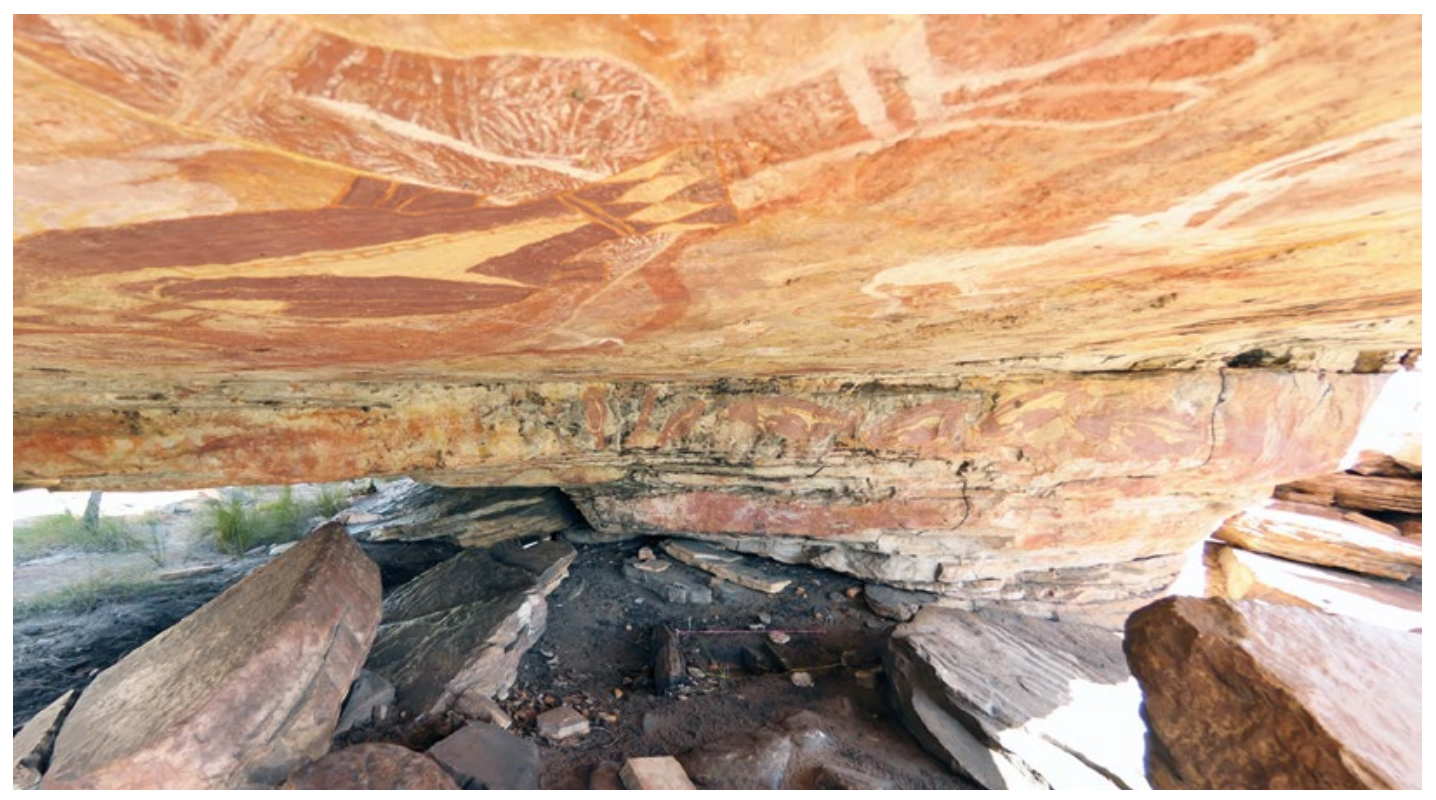

Figure 13.9 Shelter interior, looking south.

Source: Photograph by Daniel James.

The interior of the shelter is dominated by X-ray paintings in various reds and yellows, with a number of fish taxa (including saratoga, barramundi and eel-tailed catfish) and macropods represented (see Figure 13.10). Paintings are also found on some boulders under the overhang, but never as X-ray depictions. Stone artefacts are abundant on the ground just outside the shelter, as is a large volume of collapsed rock ceiling debris in part caused by quarrying of the wall. Some of the rock debris has been moved from its original position by people in times past (cf. Delannoy et al. 2013).

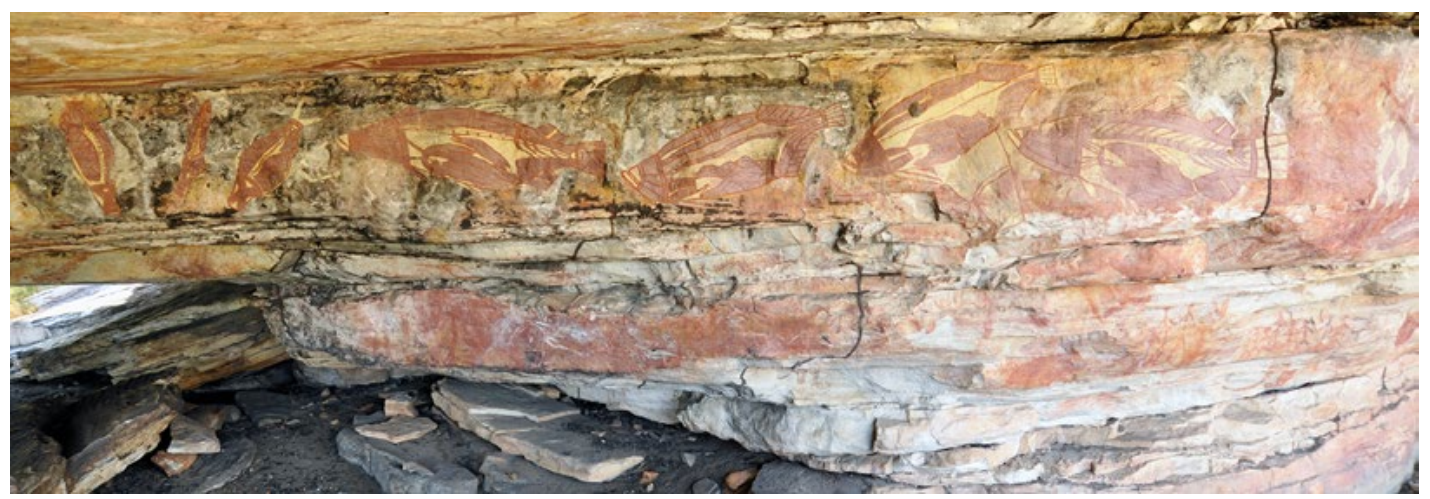

Figure 13.10 The X-ray paintings that dominate the back wall.

Source: Photograph by Daniel James. 


\section{Geophysics}

A number of natural and cultural processes such as pedogenesis, chemical weathering, burning and the addition of ochre can enhance the magnetic properties of sediments. Due to their strong association with anthropogenic fires, magnetic signals have the potential to be used as a proxy for mapping the spatial and temporal distribution of human occupation (e.g. Herries and Fisher 2010) through both field (Dalan 2007) and laboratory (Dalan and Banerjee 1998) studies. These techniques, particularly the analysis of the magnetic properties of sediments from excavations, have often been applied to rockshelter investigations, including occasionally in Australia (Lowe 2014; Marwick 2005). Far less common is the use of field magnetometry as a tool to investigate patterns of occupation in caves and rockshelters, although such methods have significant potential to map the spatial patterning of occupation within a site.

In order to investigate such spatial patterning at Dalakngalarr 1, we have measured the magnetisation of sediments across much of the rockshelter floor using a Geometrics G-856 proton precession magnetometer. The survey was undertaken using measuring tapes for positioning and employed a $1 \mathrm{~m}$ line and $0.5 \mathrm{~m}$ station spacing. Data were corrected for drift with reference to a base station, de-spiked and processed using Magpick software before being overlain on the site plan, with magnetic intensity values plotted in nanoteslas (nT) showing magnetic highs in black and magnetic lows in white with a contour interval of $20 \mathrm{nT}$ (Figure 13.11).

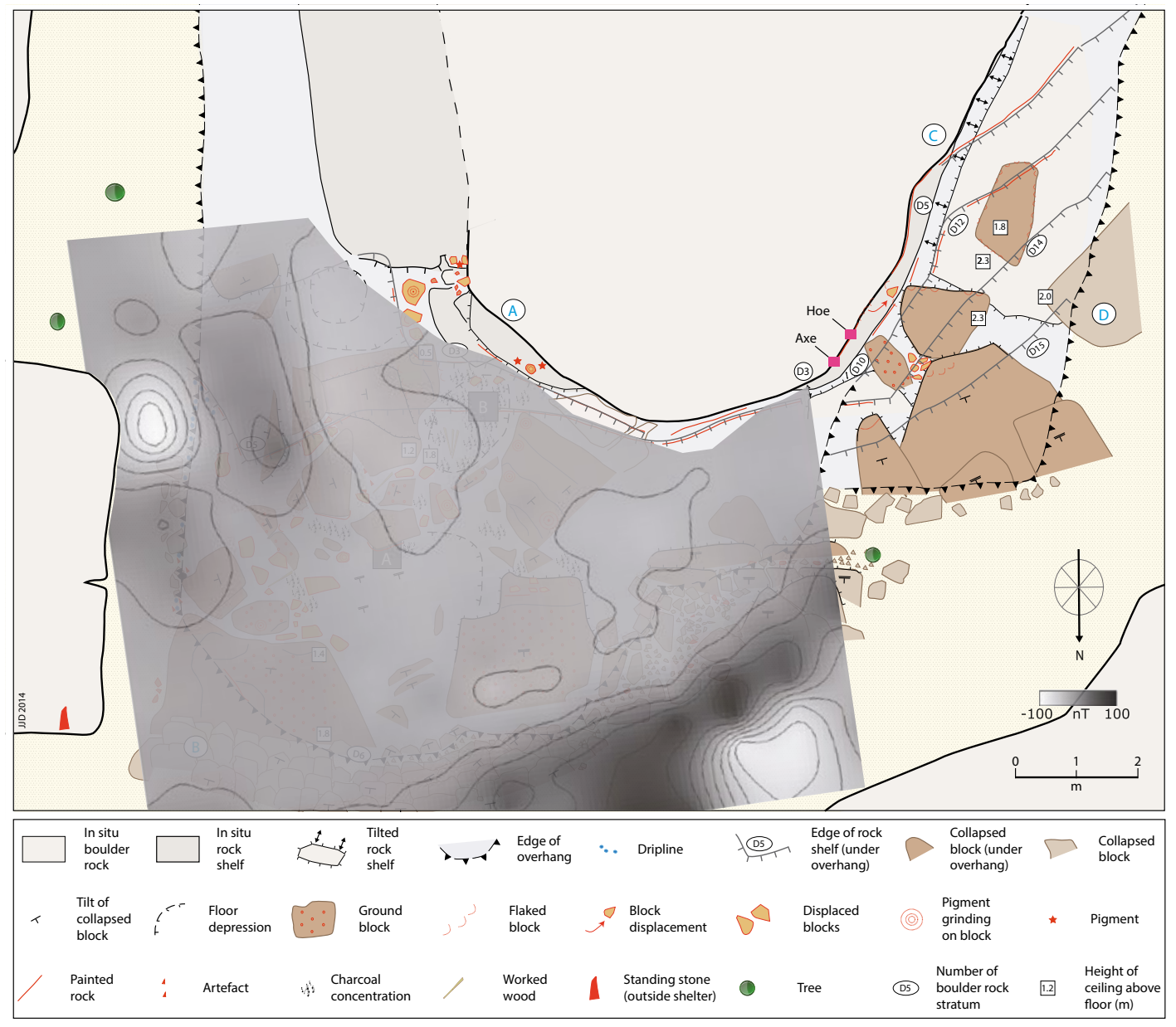

Figure 13.11 Plan of Dalakngalarr 1 showing magnetic intensity, with relative magnetic highs in black and relative magnetic lows in white.

Source: Illustration by lan Moffat and Jean-Jacques Delannoy. 
The results show that the area immediately beneath the dripline is associated with increased magnetism in all areas where this coincides with reasonably soft sediments rather than roof fall. There are areas of decreased magnetism immediately to the north, west and southeast of the dripline. The enhanced magnetism suggests that the area coincident with the dripline is either a locus of human occupation or, more likely, has the optimum combination of a suitable weathering regime, supply of organic materials and burning for magnetic enhancement. The magnetic lows may represent the background magnetic value of non-magnetic sediments sourced from the Marlgowa Sandstone (Ferenczi and Sweet 2004) of the Kombolgie Subgroup (Lane et al. 2007) that hosts the site.

Results from inside the shelter have a far more restricted range of magnetic values. Two clear trends are nevertheless apparent: areas of the shelter floor that have 1) blocks of roof fall; or 2) soft sediments adjacent to the back (south) of the shelter have lower levels of magnetic enhancement than sediments elsewhere in the site. This indicates both the inability of occupation to enhance bedrock magnetism and the probable lower intensity of occupation at the back of the shelter where the roof is closer to the ground. The extensive amount of roof fall at Dalakngalarr 1 precludes a more rigorous analysis of the spatial distribution of the magnetic signal within the major occupation area.

Further magnetic analyses at Dalakngalarr 1 are in progress, including magnetic susceptibility measurements, anhyseretic remanent magnetisation, saturation isothermal remanent magnetisation, hysteresis loops and high and low magnetic temperature magnetic measurements of the sediments from excavations. The results of these investigations will define the source of magnetism in the rockshelter sediments and enable us to explore its changes over time.

\section{The excavations}

These observations prompted archaeological excavations in what appeared from surface clues to be the thickest soft deposits of the shelter's interior (Figures 13.2, 13.12 and 13.13). Permission to excavate was provided by Traditional Owner and Buyhmi clan Elder Margaret Katherine, both directly and formally through the Jawoyn Association. Due to the relatively small exposed space between boulders inside the shelter, it was decided that two separate $50 \times 50 \mathrm{~cm}$ excavation squares (Squares A and B) would be opened, to help give an archaeological context to the rock art, in particular that of the European-contact period (see below), the X-ray art (Figure 13.10), the macropod painting on a boulder on the floor (Figure 13.14) and the paintings on the main ceiling (e.g. Figures 13.15).

Square A was positioned toward the middle of the shelter, c. $3.5 \mathrm{~m}$ inside the northern entrance (Figure 13.2). It was placed against a boulder collapsed from the ceiling, the northern, exposed face of which was subsequently painted with a red-infill macropod (Figures 13.13 and 13.14). Above the painted boulder the ceiling's surface is staggered rather than smooth, marked by negative scars of past collapses (Figure 13.16). In this part of the site, the dark sandy ground is littered with charcoal and leaf litter, indicating a likely area of inhabited space. We hoped to date the rock collapse event that brought down the boulder, now partly buried, on which the red macropod was then painted. 


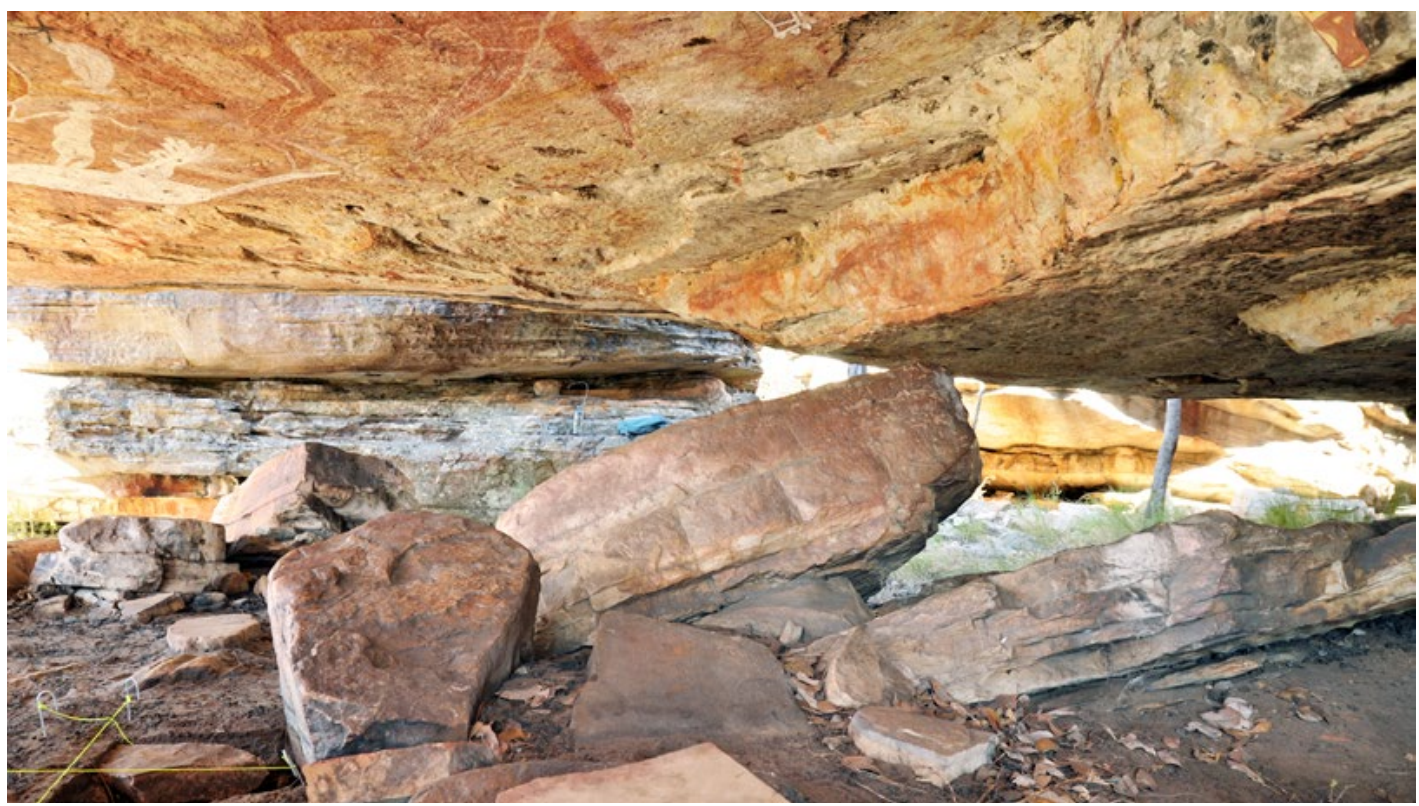

Figure 13.12 View from western side inside the shelter, looking eastward across Square A.

Source: Photograph by Daniel James.

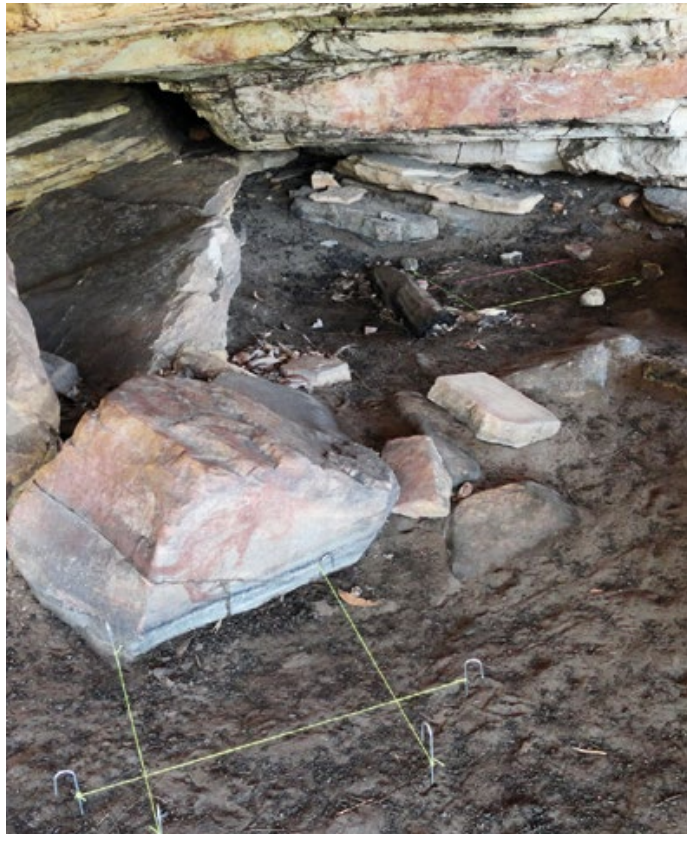

Figure 13.13 Square A (front) and Square B (rear) inside the shelter, prior to excavation. Source: Photograph by Daniel James.

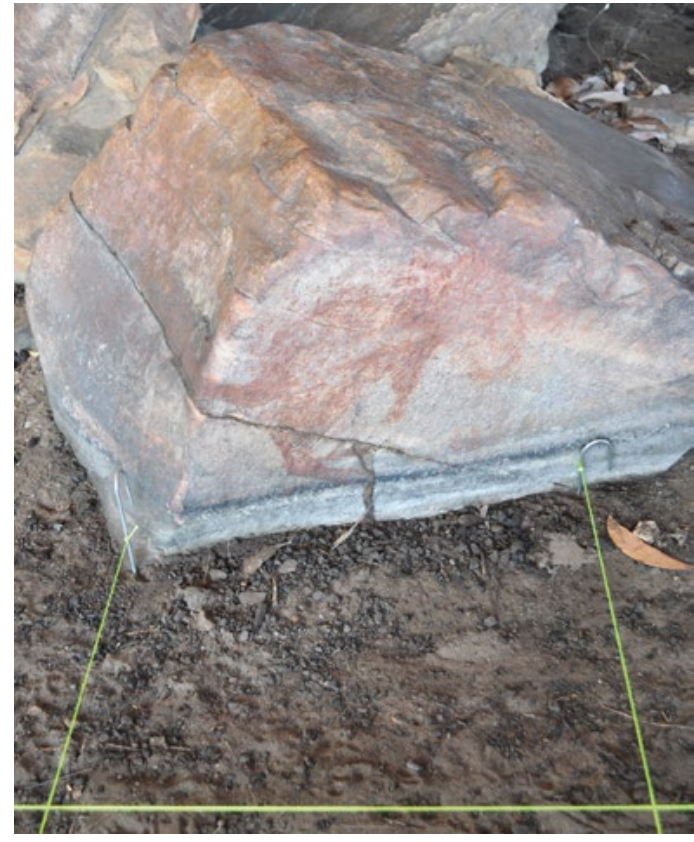

Figure 13.14 Square A prior to excavation, positioned against the boulder with painted macropod.

Source: Photograph by Bruno David. 


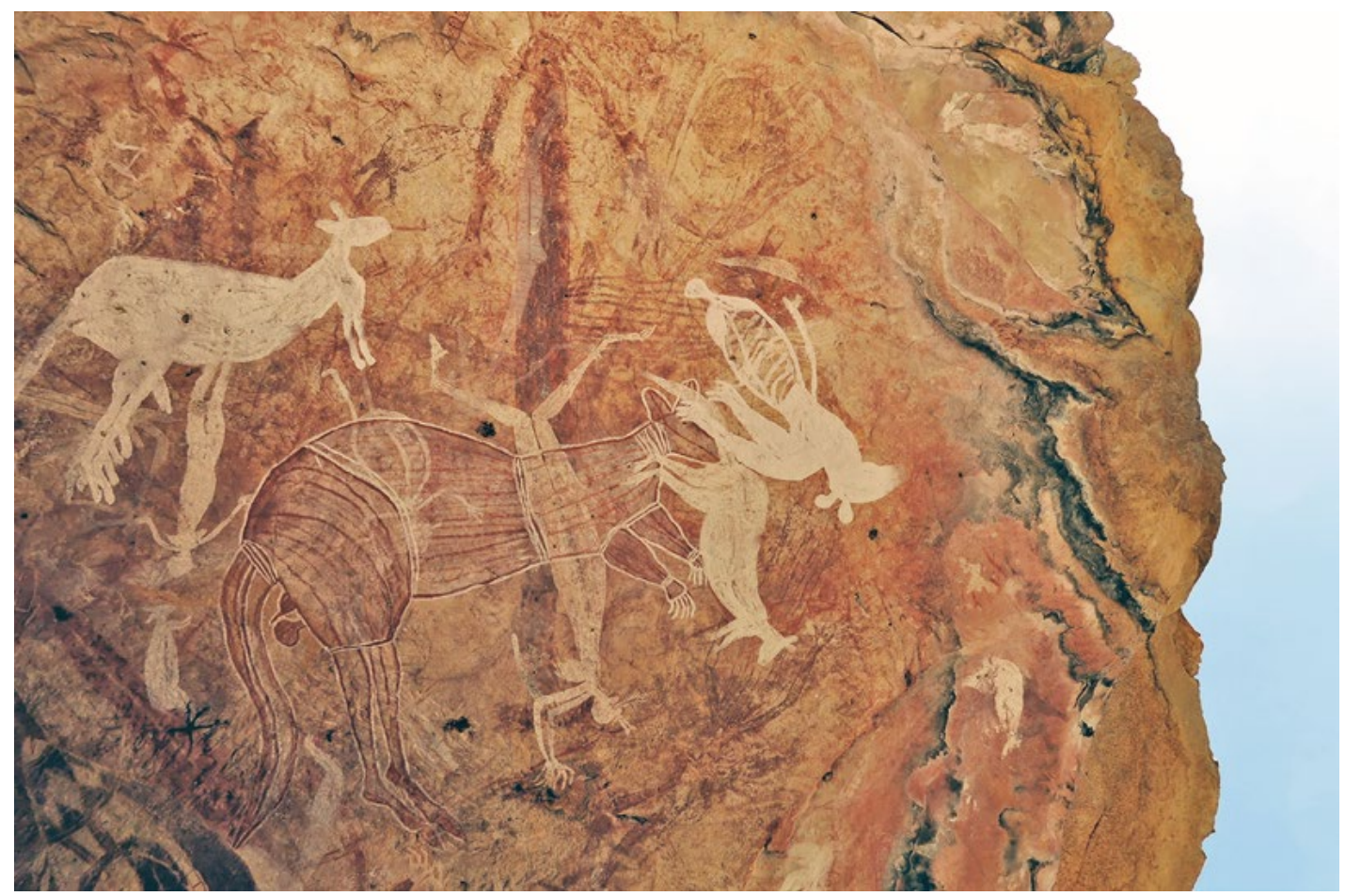

Figure 13.15 Rock art on the main ceiling.

Source: Photograph by Daniel James.

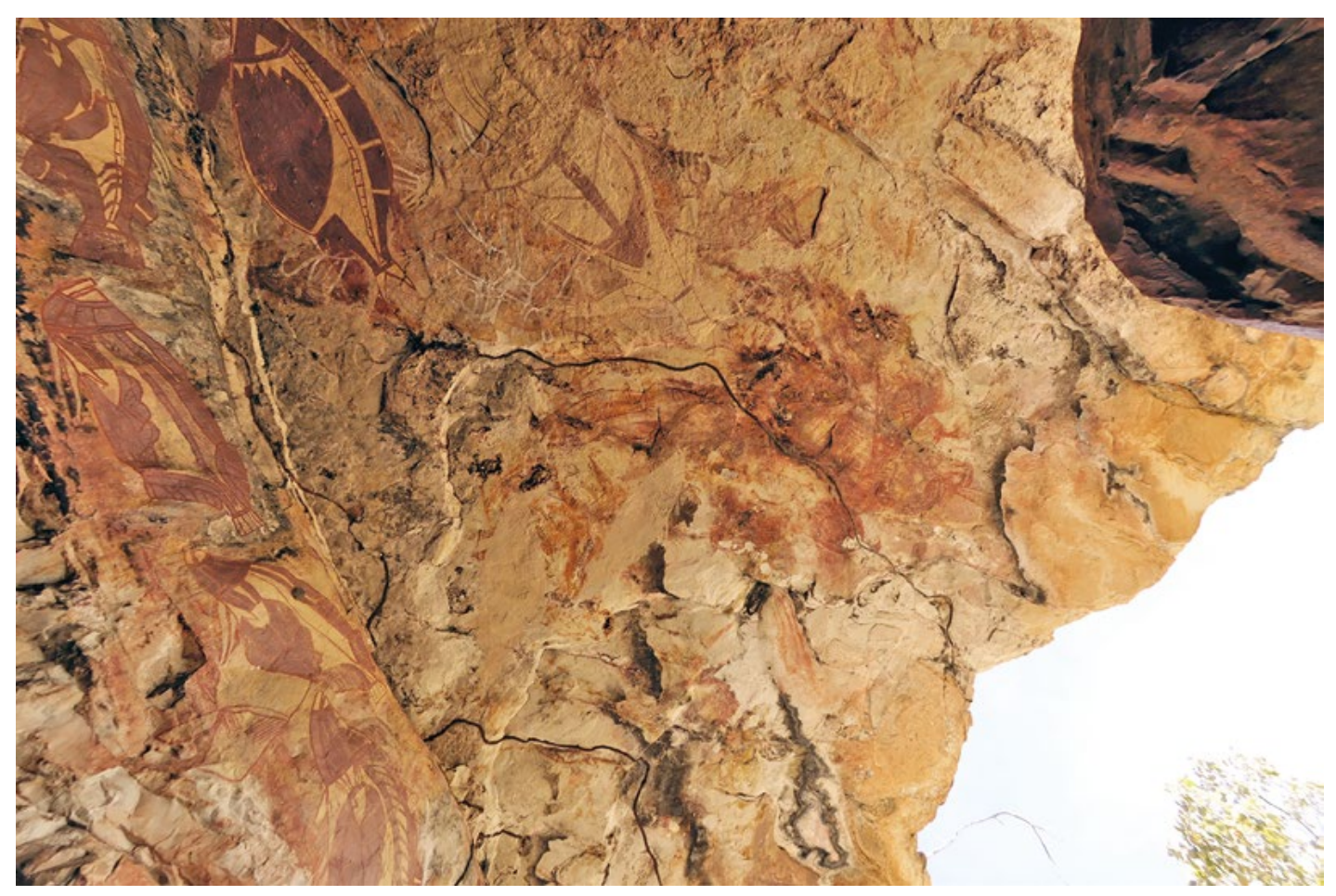

Figure 13.16 Staggered ceiling surface, indicating a history of collapse.

Source: Photograph by Daniel James. 
Square B was positioned c. $2.5 \mathrm{~m}$ to the southwest of Square A, in an area of darkened surface sediments close to the rear wall and adjacent to a partially burned log with cut marks made by a metal blade; it had potential to produce buried materials from the European-contact period associated with the cut $\log$ (Figures 13.2, 13.13, 13.17 and 13.18). Square B might also contain buried exfoliated or otherwise detached pieces of painted rock, by stratigraphic association giving ages for the deposition of the decorated rocks, and thereby minimum ages for the art, as the ceiling and rear wall in this part of the shelter are heavily painted (Figure 13.19).

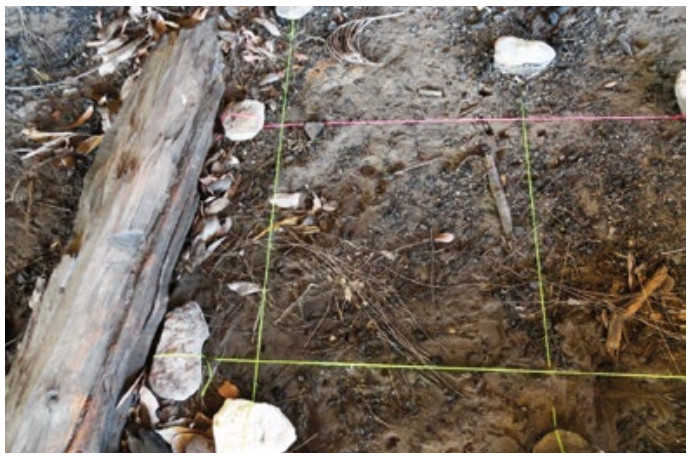

Figure 13.17 Square B prior to excavation.

Note the log with metal blade cut marks immediately to the left (east) of the excavation square. The pink string represents the south side of the square.

Source: Photograph by Daniel James.

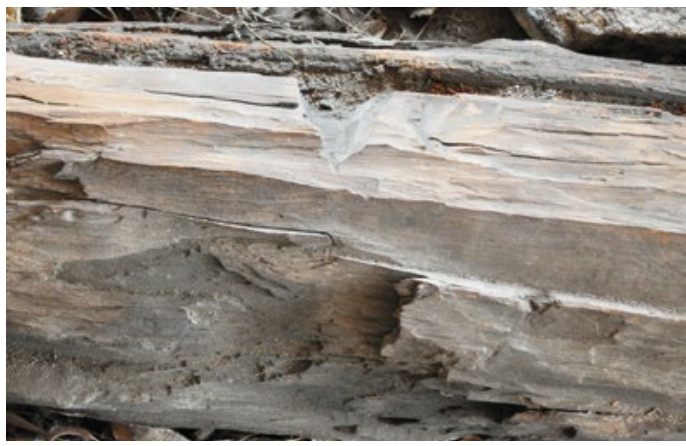

Figure 13.18 Details of metal blade cut marks on hardwood log near Square B.

Source: Photograph by Bruno David.

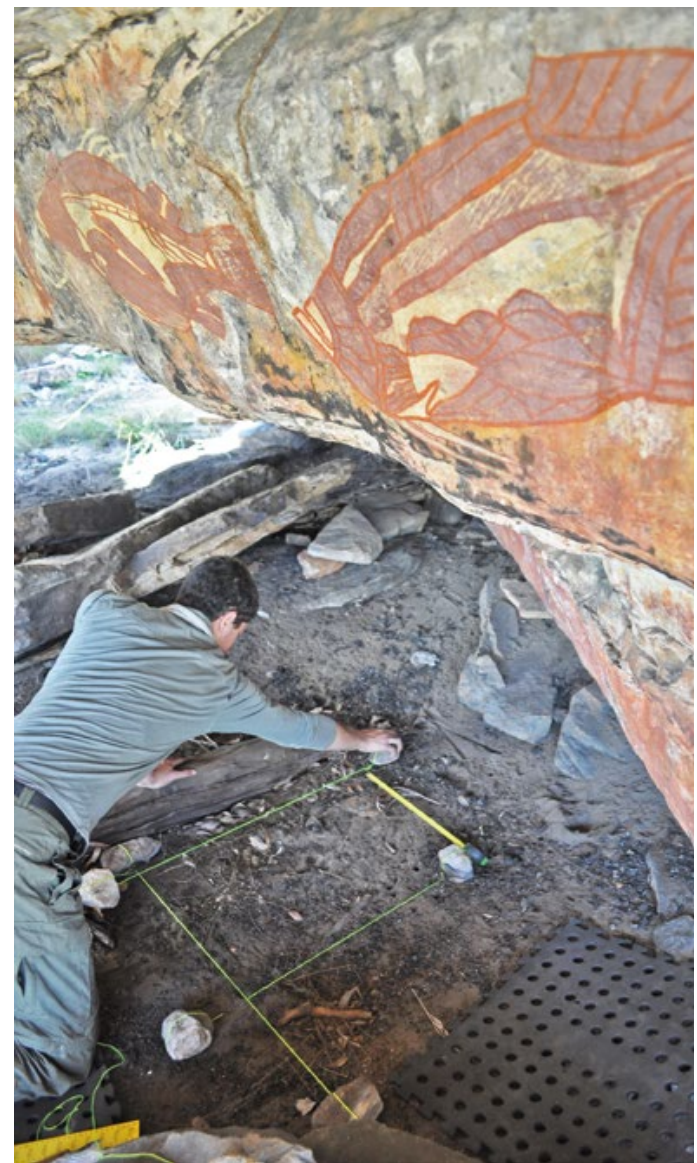

Figure 13.19 Chris Urwin stringing up Square B prior to excavation.

Source: Photograph by Bruno David.

The two squares were excavated in arbitrary units (XUs) following the stratigraphy where observed. The mean thickness of XUs was $2.9 \mathrm{~cm}$ for Square A and $1.3 \mathrm{~cm}$ for Square B. Unsieved sediment samples weighing 50-100 g were taken from each XU, the remaining excavated sediments being dry-sieved in $2 \mathrm{~mm}$ mesh over a tarpaulin some $40 \mathrm{~m}$ away. The sieved material was doublebagged on-site, packaged and shipped to Monash University for sorting and analysis.

The position of artefacts $\geq 2 \mathrm{~cm}$ long observed during excavation was recorded in three-dimensions (3-D); these artefacts were then individually bagged. A small number of charcoal pieces were also selectively sampled for 3-D recording and individual bagging from each XU. Some of these charcoal samples were then submitted for AMS radiocarbon dating. Field photographs were taken at the base of each $\mathrm{XU}$, and photographs and section drawings were made of wall profiles at the completion of excavation. The bulk-bagged excavated materials retained in the sieves were subsequently wet-sieved at Monash University, again using a $2 \mathrm{~mm}$ mesh sieve. The material 
was then air-dried for 3-5 days, rebagged and stored under controlled laboratory conditions (Figure 13.20). All excavated materials were minimally handled during excavation, sieving and laboratory sorting and analysis.

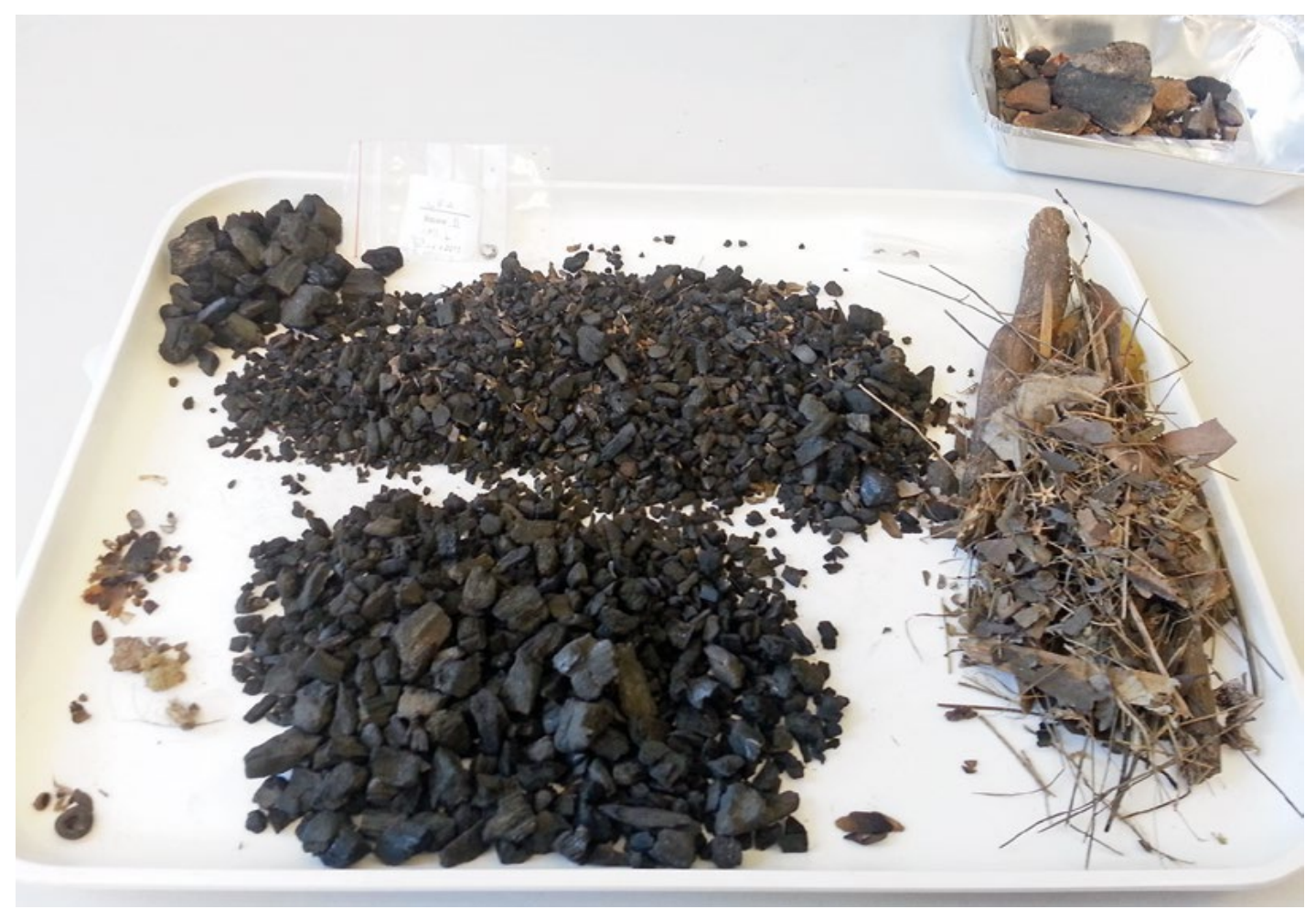

Figure 13.20 Sorting in progress, excavated materials from Square B XU1.

Source: Photograph by Bruno David.

\section{Square A results}

Square A was excavated to a maximum depth of $20 \mathrm{~cm}$, within which three major stratigraphic units (SUs) were identified (Tables 13.3 and 13.4; Figure 13.21). The topmost SU1 (excavated as XU1) consists of loose surface sediments containing charcoal and stone artefacts. Live and deceased insects are frequent in this layer, with antlions (Myrmeleontidae) being the most notable. Antlion nymphs live in soft sandy soil, making small and shallow cone-shaped pits into which ants and other soil arthropods fall and get eaten. The pits created by the nymphs have a depth of c. $2 \mathrm{~cm}$, causing limited impacts on the site's stratigraphy (Valerie Caron, pers. comm. to Daniel James 2013). The bulk of cultural materials came from SU2 (excavated mainly as XU2XU4), including three heavily rusted conjoining nail-like metal pieces recovered from the top of SU2 (Table 13.5). Limited debris from ceiling rock collapse was evident from XU2 (in SU2) downwards, but in SU3 large rocks from ceiling collapse appear in earnest. This culminated in XU7 at the base of SU3, a very rocky level spanning the entire width of the square and thus left in situ. At the base of XU7, only a narrow fissure some $7 \mathrm{~cm}$ wide remained exposed between what appears to be a split rock slab. That narrow fissure was filled with soft sandy sediments including charcoal. Exposed rock near the base of SU3 predominantly lies flat (Figures 13.21 and 13.22). The rock fissure signalled that further soft sediments occur below the large rocks at the base of the excavation: bedrock had not been reached. The base of the large boulder with the red-painted macropod that marked the southern edge of Square A was encountered in XU6 within mid-levels of SU3. There was no sediment between the bottom of that boulder and the top of the flat rock 
surface on which it lay. The boulder with the macropod painting thus fell into place sometime after XU7 had been fully laid down, and after XU6 sediments had begun to deposit (see below for dating). The red macropod was painted sometime after that.

Table 13.3 Details of Excavation Units, Dalakngalarr 1, Square A.

\begin{tabular}{|l|c|r|r|r|r|r|r|r|}
\hline XU & SU & $\begin{array}{c}\text { Mean depth } \\
\text { at top }(\mathbf{c m})\end{array}$ & $\begin{array}{c}\text { Mean depth at } \\
\text { centre }(\mathbf{c m})\end{array}$ & $\begin{array}{c}\text { Mean depth } \\
\text { at base }(\mathbf{c m})\end{array}$ & $\begin{array}{c}\text { Mean thickness } \\
(\mathbf{c m})\end{array}$ & $\begin{array}{l}\text { Area } \\
\left(\mathbf{m}^{2}\right)\end{array}$ & Weight $(\mathbf{k g})$ & $\begin{array}{l}\text { Volume } \\
(\text { litres })\end{array}$ \\
\hline 1 & 1 & 0.0 & 0.4 & 0.8 & 0.8 & 0.22 & 2.0 & 1.5 \\
\hline 2 & 2 & 0.8 & 1.4 & 1.9 & 1.1 & 0.19 & 2.5 & 2.5 \\
\hline 3 & 2 & 1.9 & 2.5 & 3.0 & 1.1 & 0.18 & 2.7 & 2.5 \\
\hline 4 & $2+3$ & 3.0 & 3.9 & 4.8 & 1.8 & 0.16 & 3.7 & 3.0 \\
\hline 5 & $2+3$ & 4.8 & 6.2 & 7.5 & 2.7 & 0.16 & 5.6 & 4.0 \\
\hline 6 & 3 & 7.5 & 10.6 & 13.7 & 6.2 & 0.03 & 25.3 & 16.0 \\
\hline 7 & 3 & 13.7 & 16.9 & 20.0 & 6.3 & 0.02 & 1.2 & 1.0 \\
\hline
\end{tabular}

SU numbers in bold indicate that most of the square is taken up by those SUs.

Source: Authors' data.

Table 13.4 Stratigraphic Units, Dalakngalarr 1, Square A.

\begin{tabular}{|l|l|}
\hline SU & Description of sediments \\
\hline 1 & $\begin{array}{l}\text { Dark grey to dark grey-brown, loose surface ashy sand. Stone artefacts present. Organic matter present in the form } \\
\text { of wind-blown leaves; charcoal pieces up to } 2 \mathrm{~cm} \text { in length are abundant. Small insects present. Interface with SU2 } \\
\text { is marked. }\end{array}$ \\
\hline 2 & $\begin{array}{l}\text { Dark grey to dark grey-brown, slightly compact and consolidated sandy sediments. Stone artefacts continue to be } \\
\text { present. Small, fibrous rootlets are common, with charcoal pieces continuing to be abundant. Interface with SU3 } \\
\text { is marked. }\end{array}$ \\
\hline 3 & $\begin{array}{l}\text { Grey to dark grey sandy loam, slightly more humid than SU2 at the time of excavation. In upper levels of SU3, } \\
\text { stone artefacts are more numerous than in su2. Small, fibrous rootlets continue to appear but are less frequent } \\
\text { with depth. Sediments are moderately compact and well consolidated. At base of su3, including the crack between } \\
\text { flat rocks, frequency of both stone artefacts and charcoal decreases. }\end{array}$ \\
\hline
\end{tabular}

Source: Authors' data.

Table 13.5 List of excavated materials by XU, highlighted by SU, Dalakngalarr 1, Square A.

\begin{tabular}{|c|c|c|c|c|c|c|c|c|c|c|c|}
\hline \multirow[t]{2}{*}{$\mathrm{XU}$} & \multirow[t]{2}{*}{ SU } & \multirow[t]{2}{*}{ Charcoal (g) } & \multicolumn{2}{|c|}{ Stone artefacts } & \multicolumn{2}{|c|}{ Ochre } & \multicolumn{2}{|c|}{$\begin{array}{l}\text { Metal } \\
\text { pieces }\end{array}$} & \multirow[t]{2}{*}{$\begin{array}{l}\text { Insects } \\
\text { (g) }\end{array}$} & \multirow{2}{*}{$\begin{array}{l}\text { Roots and } \\
\text { other plant } \\
\text { matter }(g)\end{array}$} & \multirow{2}{*}{$\begin{array}{l}\text { Scat from } \\
\text { unidentified } \\
\text { fauna }(g)\end{array}$} \\
\hline & & & $\#$ & $g$ & $\#$ & $g$ & $\#$ & $g$ & & & \\
\hline 1 & 1 & 159.87 & 101 & 16.09 & & & & & 0.02 & 3.58 & 2.59 \\
\hline 2 & 2 & 109.75 & 73 & 9.28 & & & 2 & 1.04 & 0.03 & 1.83 & \\
\hline 3 & 2 & 72.22 & 83 & 44.67 & & & 1 & 0.45 & 0.03 & 3.24 & \\
\hline 4 & $2+3$ & 63.87 & 147 & 32.88 & & & & & 0.03 & 9.44 & \\
\hline 5 & $2+3$ & 65.47 & 246 & 806.81 & 1 & 0.58 & & & 0.01 & 5.88 & \\
\hline 6 & 3 & 40.16 & 132 & 339.44 & 1 & 36.2 & & & 0.02 & 25.99 & \\
\hline 7 & 3 & 0.05 & & & & & & & & & \\
\hline \multicolumn{2}{|c|}{ Total } & 511.39 & 782 & 1249.17 & 2 & 36.78 & 3 & 1.49 & 0.14 & 50.0 & 2.59 \\
\hline
\end{tabular}

SU numbers in bold indicate that most of the square is taken up by these SUs.

Source: Authors' data.

Stone artefact numbers, and even more so total weights, peaked in XU5 and XU6 in the upper levels of SU3. The only evidence of earth pigments came from this same stratigraphic level that also saw peak artefact numbers (XU5-XU6), indicating a period of heightened site use that included stone artefact flaking and painting activity. No stone artefacts were recovered from the base of the narrow fissure between rocks in XU7, but this could be a function of the very limited surface area covered by the fissure (Table 13.5). 


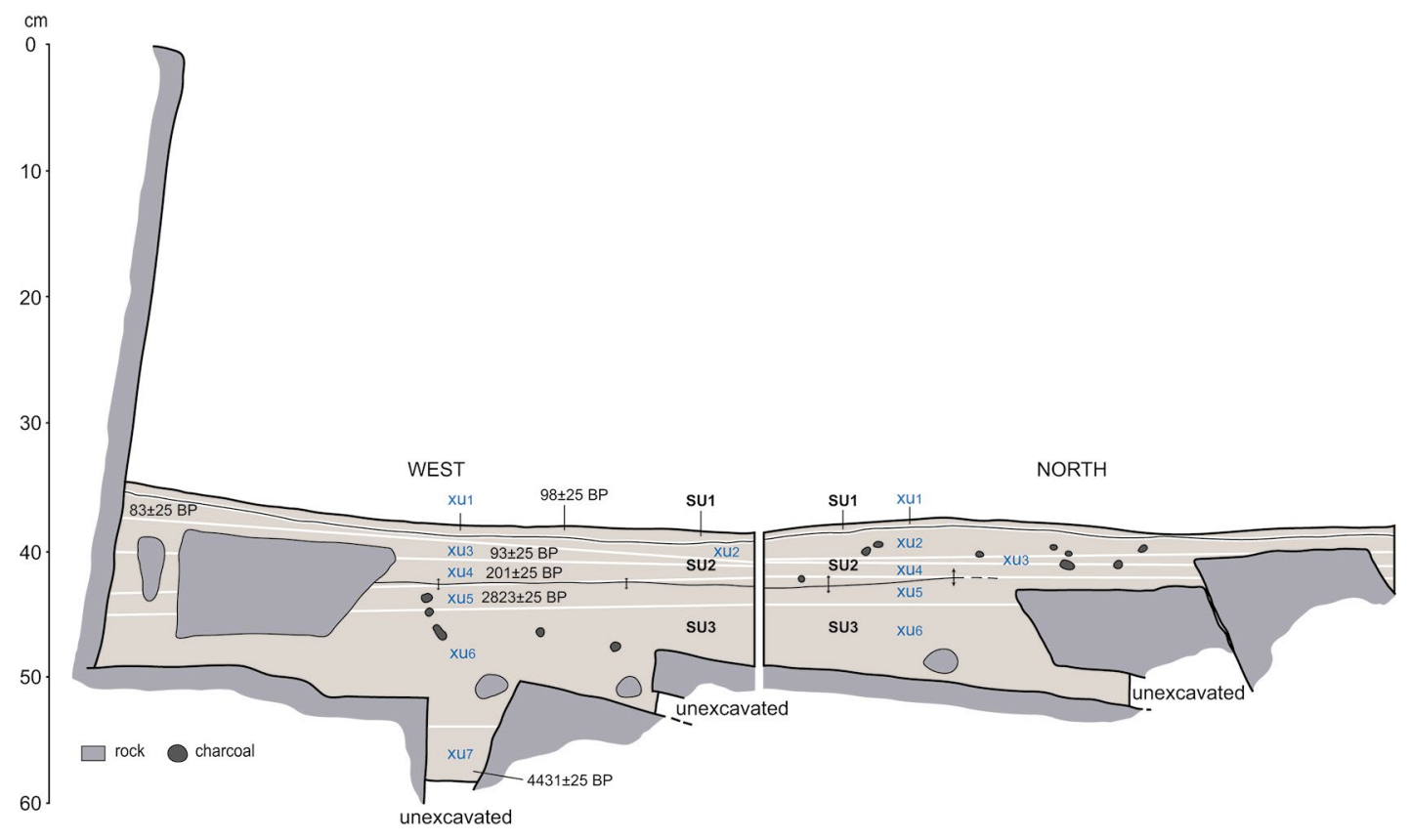

Figure 13.21 West and north sections of Square A, showing back-plotted XUs.

The rock surface that slants near-vertically above the top of the excavated sediments on the western section is the side of the boulder with the red-painted macropod seen in Figures 13.14 and 13.22 .

Source: Illustration by Kara Rasmanis and Bruno David.

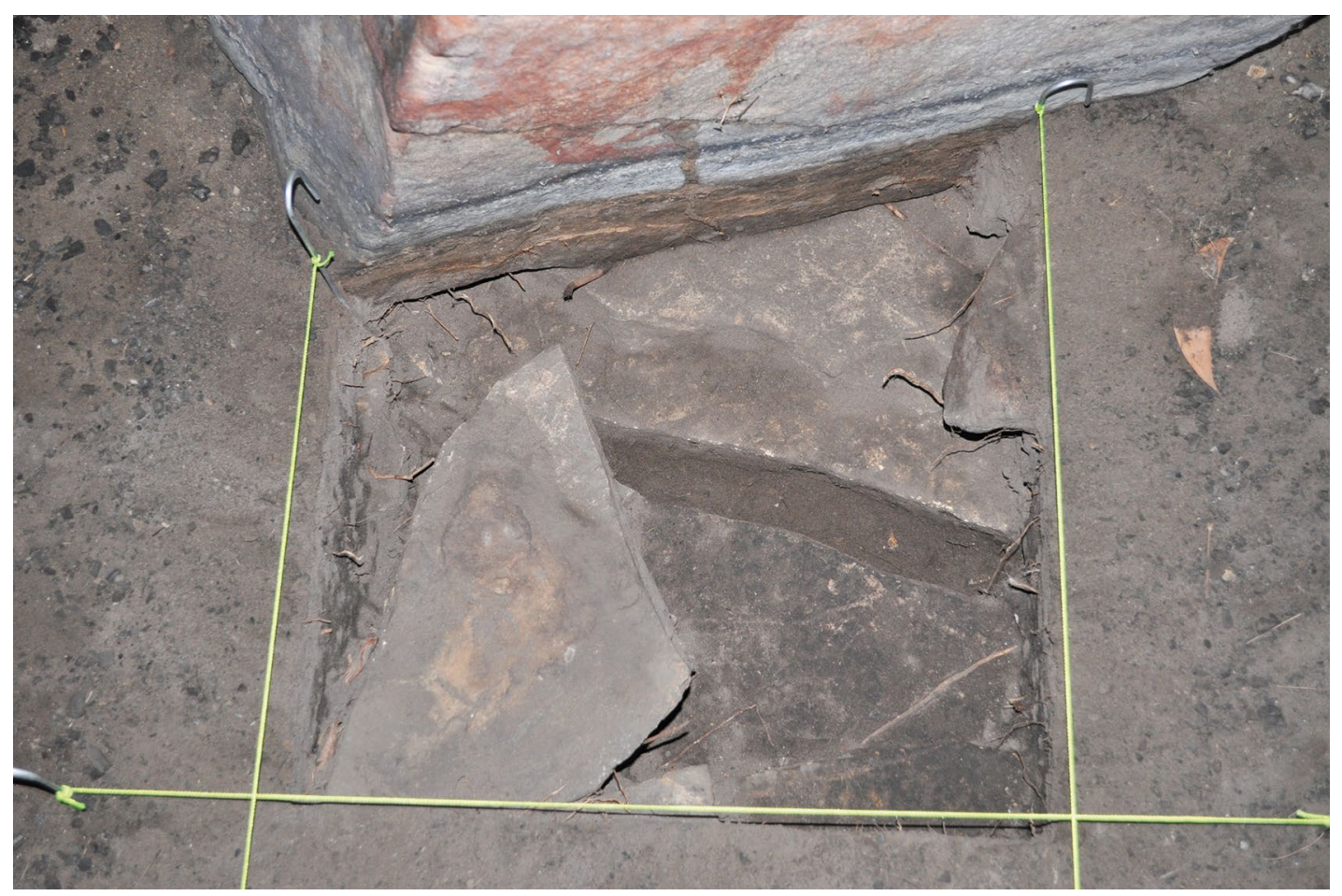

Figure 13.22 Rocks at base of Square A excavation.

Source: Photograph by Bruno David. 


\section{Square B results}

Square B was excavated to a maximum depth of $21 \mathrm{~cm}$ (Table 13.6). It contains five SUs, each homogeneous in colour and texture across the square and down the deposit (Table 13.7; Figure 13.23). The topmost SU1A (excavated as XU1-XU2) consists of disturbed surface sediments. As was the case with Square A, live and dead insects are frequent in this layer, with antlions again being the most notable. A single glass bead was recovered from XU2 at the SU1ASU1B interface. Quantities of stone artefacts are somewhat constant throughout XU1-XU8 in SU1A and SU1B, decreasing markedly in the lower, and older, SU1C and SU1D, beginning with XU9 (Table 13.8). Rocks were relatively sparse until XU9, where bedrock became exposed in the northeastern, northwestern and southwestern parts of the square. From XU8 downwards, disintegrating sandstone pebbles of SU2 became increasingly frequent across the square. The area of disintegrating sandstone became more expansive with depth, until it gave way to bedrock across the entire square in XU16. SU2 is culturally sterile (Figures 13.23 and 13.24).

Table 13.6 Details of Excavation Units, Dalakngalarr 1, Square B.

\begin{tabular}{|c|c|c|c|c|c|c|c|c|}
\hline$X U$ & SU & $\begin{array}{l}\text { Mean depth } \\
\text { at top }(\mathrm{cm})\end{array}$ & $\begin{array}{c}\text { Mean depth at } \\
\text { centre }(\mathrm{cm})\end{array}$ & $\begin{array}{c}\text { Mean depth at } \\
\text { base }(\mathrm{cm})\end{array}$ & \begin{tabular}{|c|} 
Mean \\
thickness $(\mathrm{cm})$ \\
\end{tabular} & $\begin{array}{l}\text { Area } \\
\left(\mathrm{m}^{2}\right)\end{array}$ & $\begin{array}{l}\text { Weight } \\
(\mathrm{kg})\end{array}$ & $\begin{array}{l}\begin{array}{l}\text { Volume } \\
\text { (litres) }\end{array} \\
\end{array}$ \\
\hline 1 & $1 \mathrm{~A}$ & 0.0 & 0.6 & 1.1 & 1.1 & 0.25 & 2.9 & 2.5 \\
\hline 2 & $1 \mathrm{~A}+1 \mathrm{~B}$ & 1.1 & 1.9 & 2.6 & 1.5 & 0.25 & 4.1 & 3.0 \\
\hline 3 & $1 \mathrm{~B}$ & 2.6 & 2.9 & 3.2 & 0.6 & 0.25 & 2.1 & 2.0 \\
\hline 4 & $1 \mathrm{~B}$ & 3.2 & 4.1 & 5.0 & 1.8 & 0.24 & 4.5 & 3.5 \\
\hline 5 & $1 \mathrm{~B}$ & 5.0 & 5.5 & 6.0 & 1.0 & 0.23 & 3.5 & 3.5 \\
\hline 6 & $1 \mathrm{~B}+1 \mathrm{C}$ & 6.0 & 6.9 & 7.9 & 1.9 & 0.22 & 4.8 & 4.0 \\
\hline 7 & $1 \mathrm{~B}+1 \mathrm{C}$ & 7.9 & 8.6 & 9.3 & 1.4 & 0.22 & 3.7 & 3.5 \\
\hline 8 & $1 \mathrm{~B}+1 \mathrm{C}$ & 9.3 & 9.6 & 10.0 & 0.7 & 0.21 & 2.9 & 2.0 \\
\hline 9 & $1 C+1 D+2$ & 10.0 & 10.6 & 11.3 & 1.3 & 0.11 & 3.3 & 2.5 \\
\hline 10 & $1 C+1 D+2$ & 11.3 & 12.1 & 12.9 & 1.6 & 0.13 & 2.1 & 1.5 \\
\hline 11 & $1 C+1 D+2$ & 12.9 & 13.3 & 13.7 & 0.8 & 0.09 & 1.7 & 1.0 \\
\hline 12 & $1 C+1 D+2$ & 13.7 & 14.1 & 14.5 & 0.8 & 0.04 & 3.0 & 2.0 \\
\hline 13 & $1 C+2$ & 14.5 & 15.0 & 15.5 & 1.0 & 0.03 & 2.2 & 1.5 \\
\hline 14 & $1 C+2$ & 15.5 & 15.7 & 15.9 & 0.4 & 0.03 & 2.0 & 1.0 \\
\hline 15 & 2 & 15.9 & 17.8 & 19.8 & 3.9 & 0.01 & 1.5 & 1.0 \\
\hline 16 & 2 & 19.8 & 20.4 & 21.1 & 1.3 & 0.01 & 0.5 & 0.4 \\
\hline
\end{tabular}

SU numbers in bold indicate that most of the square is taken up by those SUs.

Source: Authors' data.

Table 13.7 Stratigraphic Units, Dalakngalarr 1, Square B.

\begin{tabular}{|l|l|}
\hline SU & Description \\
\hline 1A & $\begin{array}{l}\text { Loose, dry, ashy, dark grey to dark grey-brown sand. Disturbed surface sediments. Charcoal is abundant. Some } \\
\text { wind-blown leaves present, but no plants are growing on the site floor. Stone artefacts are present. Interface with } \\
\text { SU1A is gradual. }\end{array}$ \\
\hline 1B & $\begin{array}{l}\text { Loose, dry, ashy, dark grey to dark grey-brown sand. Sediments are slightly more consolidated but otherwise much } \\
\text { like SU1A. Rootlets are present. Stone artefacts are present. }\end{array}$ \\
\hline 1C & $\begin{array}{l}\text { Sediments are very rich in charcoal and more blackish than SU1A or SU1B. SU1C sediments are more consolidated, } \\
\text { more compact ashy sands than overlying sediments. Interface with SU1B takes place over 2-3 cm vertical depth. } \\
\text { Boundary with SU2 is marked. Quantities of stone artefacts are moderate in the uppermost levels of this SU as it } \\
\text { interfaces with SU1B, but rapidly decline at lower levels. }\end{array}$ \\
\hline
\end{tabular}




\begin{tabular}{|l|l|}
\hline SU & Description \\
\hline 10 & $\begin{array}{l}\text { Sediments are much like SU1C but lighter grey ashy sand, although here charcoal is less abundant. Interface with } \\
\text { SU1B and SU1C takes place over 1-2 cm vertical depth. SU1D immediately overlies SU2; SU1D sediments occur } \\
\text { within cracks in the uppermost, fragmenting SU2 sandstone rocks. SU1D is not present across the whole square, } \\
\text { but restricted mainly to its northern half. Small amounts of stone artefacts are present in decreasing numbers } \\
\text { with depth. }\end{array}$ \\
\hline 2 & $\begin{array}{l}\text { Disintegrating soft reddish sandstone rocks representing a layer of soft sandstone immediately overlying a hard rock } \\
\text { surface that is probably bedrock. SU1C and SU1D sediments are present between disintegrating sandstone pieces. } \\
\text { SU2 rocks tend to be more tabular and less disintegrating in the northern half of the square than in higher SUs. SU2 } \\
\text { is culturally sterile. }\end{array}$ \\
\hline
\end{tabular}

Source: Authors' data.

Table 13.8 General list of excavated materials by XU, Dalakngalarr 1, Square B.

\begin{tabular}{|c|c|c|c|c|c|c|c|c|c|c|}
\hline \multirow[t]{2}{*}{$\mathrm{XU}$} & \multirow[t]{2}{*}{ SU } & \multirow{2}{*}{$\begin{array}{c}\text { Charcoal } \\
\text { (g) }\end{array}$} & \multicolumn{2}{|c|}{ Stone artefacts } & \multicolumn{2}{|c|}{ Glass bead } & \multirow{2}{*}{$\begin{array}{l}\text { Insects } \\
\text { (g) }\end{array}$} & \multirow{2}{*}{$\begin{array}{l}\text { Roots and } \\
\text { other plant } \\
\text { matter }(\mathrm{g})\end{array}$} & \multirow{2}{*}{$\begin{array}{l}\text { Scat from } \\
\text { unidentified } \\
\text { fauna }(g)\end{array}$} & \multirow{2}{*}{$\begin{array}{l}\text { Hair and fur from } \\
\text { unidentified } \\
\text { fauna }\end{array}$} \\
\hline & & & $\#$ & $g$ & $\#$ & g & & & & \\
\hline 1 & $1 \mathrm{~A}$ & 173.18 & 52 & 12.94 & & & 0.45 & 36.54 & 0.43 & 2.10 \\
\hline 2 & $1 \mathrm{~A}+1 \mathrm{~B}$ & 163.82 & 83 & 42.21 & 1 & 0.04 & 0.19 & 10.71 & & \\
\hline 3 & $1 \mathrm{~B}$ & 70.26 & 50 & 4.67 & & & 0.19 & 0.91 & & 0.01 \\
\hline 4 & $1 \mathrm{~B}$ & 141.01 & 87 & 121.87 & & & 0.01 & 4.44 & & \\
\hline 5 & $1 \mathrm{~B}$ & 101.51 & 58 & 11.81 & & & 0.01 & 7.56 & & \\
\hline 6 & $1 \mathrm{~B}+1 \mathrm{C}$ & 106.6 & 51 & 6.63 & & & 0.02 & 4.62 & & \\
\hline 7 & $1 \mathrm{~B}+1 \mathrm{C}$ & 56.88 & 57 & 4.93 & & & 0.04 & 2.21 & & \\
\hline 8 & $1 \mathrm{~B}+1 \mathrm{C}$ & 31.80 & 24 & 3.94 & & & 0.12 & 2.84 & & \\
\hline 9 & $1 \mathrm{C}+1 \mathrm{D}+2$ & 18.89 & 7 & 0.46 & & & 0.01 & 1.98 & & \\
\hline 10 & $1 C+1 D+2$ & 13.29 & 8 & 0.57 & & & 0.01 & 0.98 & & \\
\hline 11 & $1 \mathrm{C}+1 \mathrm{D}+2$ & 4.56 & 3 & 0.23 & & & 0.01 & 0.73 & & \\
\hline 12 & $1 C+1 D+2$ & 3.66 & 9 & 0.33 & & & 0.01 & 0.03 & & \\
\hline 13 & $1 C+2$ & 1.58 & 13 & 6.28 & & & & 0.01 & & \\
\hline 14 & $1 C+2$ & 0.78 & 4 & 1.91 & & & & & & \\
\hline 15 & 2 & 0.19 & & & & & & 0.01 & & \\
\hline 16 & 2 & 0.04 & & & & & & & & \\
\hline Total & & 888.05 & 506 & 218.78 & 1 & 0.04 & 1.07 & 73.57 & 0.43 & 2.11 \\
\hline
\end{tabular}

SU numbers in bold indicate that most of the square is taken up by those SUs.

Source: Authors' data.
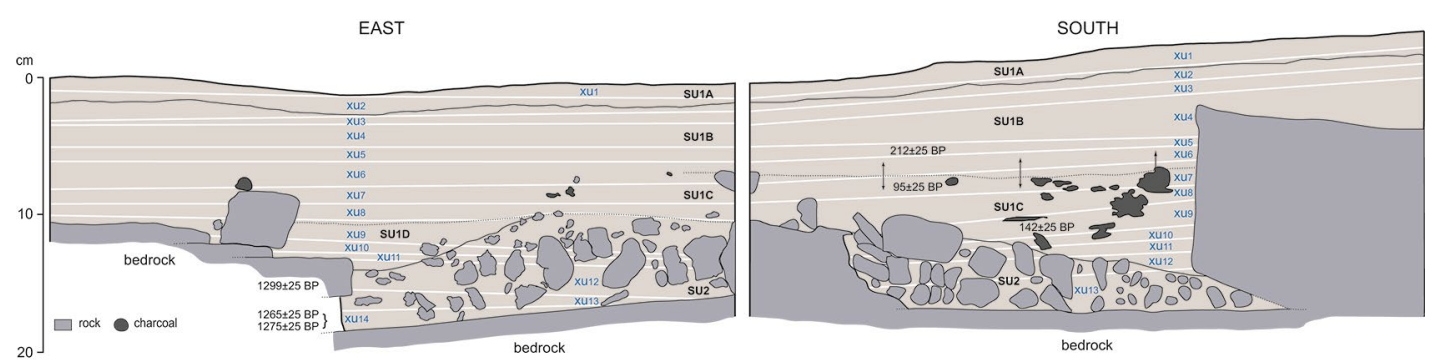

Figure 13.23 East and south sections of Square B, showing back-plotted XUs.

Source: Illustration by Kara Rasmanis and Bruno David. 


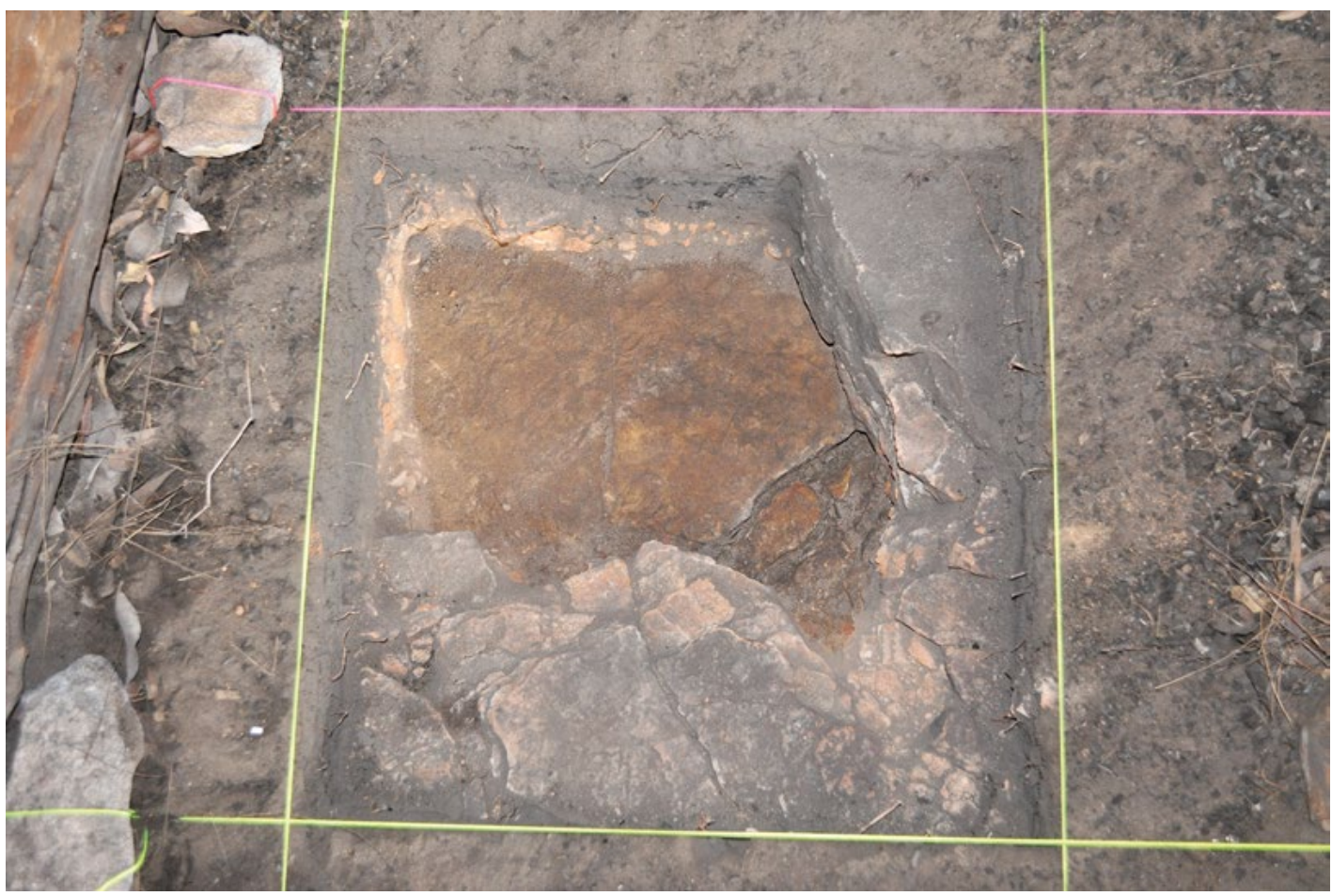

Figure 13.24 Collapsed rock over bedrock at base of Square B.

Source: Photograph by Bruno David.

The stratigraphic sequence is broadly consistent across both excavation squares, with the sum of Square B's SU1A and SU1B appearing to be spatially continuous, and contemporaneous, with SU1 and SU2 in Square A, as indicated by their relative stratigraphic positions and radiocarbon determinations (see below).

\section{Radiocarbon dating of charcoal from the excavations}

A total of twelve radiocarbon dates were obtained from Squares A and B (Table 13.9). All are AMS dates on single pieces of individually 3-D plotted wood charcoal, barring the sample from $\mathrm{XU} 7$ in Square A that was obtained from the sieve. The following discussion of calibrated ages is based on 68.3 per cent probability distributions.

The initial phase of occupation in Square A dates to sometime within the period 4969-5211 cal BP (in XU7), until 2882-2955 cal BP (in XU5). This period (Phase 1) is represented by XU7-XU5 in SU3. The dates do not permit us to determine whether occupation was continuous or intermittent (at archaeological time scales) during Phase 1. It is during this initial phase that the large boulder marking the southern side of Square A fell into position, and sometime after that the red macropod was painted on it. This part of the site then remained either unoccupied or subject to low-intensity occupation until sometime within the calibrated age range 0-290 cal BP (Phase 2). This second phase began either slightly before or during the European-contact period, as indicated by three separate radiocarbon dates each calibrating within that age range and by the presence of three conjoining pieces of metal. 
Initial occupation of the area of Square B dates from 1181-1264 cal BP to 1186-1281 cal BP, apparently an archaeologically instantaneous event. This was followed about a thousand years later by a more recent phase of occupation beginning 11-271 cal BP either shortly before, or during, the European-contact period, as indicated by the presence of a glass bead. This latter, recent phase is contemporaneous with the most recent Phase 2 of Square A.

Two broad depositional phases are thus evident from the excavated deposits:

- Phase 1, beginning 4969-5211 cal BP (Square A) and extending to 1186-1281 cal BP (Square B). The small size of the excavations does not permit us to determine whether this phase represents relatively continuous occupation, or a series of occupational pulses (as measured at archaeological time scales).

- Phase 2, beginning 0-290 cal BP (Square A), that is, either during or extending into the European-contact period, as shown by the presence of metal (Square A) and a glass bead (Square B).

Table 13.9 Radiocarbon dates from Dalakngalarr 1.

\begin{tabular}{|c|c|c|c|c|c|}
\hline$X U$ & Laboratory code & $\delta^{13} \mathrm{C} \% 0$ & ${ }^{14} \mathrm{C}$ age BP & Calibrated age BP (68.3\% probability) & Phase \\
\hline \multicolumn{6}{|c|}{ Square A } \\
\hline 1 & Wk-36131 & $-27.1 \pm 0.2$ & $98 \pm 25$ & $\begin{array}{c}32-47(0.142) \\
55-82(0.230) \\
98-107(0.070) \\
113-136(0.245) \\
224-255(0.313) \\
\end{array}$ & \multirow[t]{4}{*}{2} \\
\hline 2 & Wk-36132 & $-24.5 \pm 0.2$ & $83 \pm 25$ & $\begin{array}{c}34-72(0.498) \\
116-134(0.207) \\
227-252(0.296) \\
\end{array}$ & \\
\hline 3 & Wk-36133 & $-25.4 \pm 0.2$ & $93 \pm 25$ & $\begin{array}{c}33-73(0.424) \\
102-105(0.025) \\
114-136(0.230) \\
225-254(0.321)\end{array}$ & \\
\hline 4 & Wk-36134 & $-25.1 \pm 0.2$ & $201 \pm 25$ & $\begin{array}{c}0-11(0.183) \\
150-186(0.537) \\
272-290(0.280)\end{array}$ & \\
\hline 5 & Wk-35506 & $-25.6 \pm 0.2$ & $2823 \pm 25$ & $\begin{array}{l}2882-2911(0.432) \\
2918-2955(0.568)\end{array}$ & \multirow[t]{2}{*}{1} \\
\hline 7 & Wk-35505 & $-25.2 \pm 0.2$ & $4431 \pm 25$ & $\begin{array}{l}4969-5049(0.902) \\
5197-5211(0.098)\end{array}$ & \\
\hline \multicolumn{6}{|c|}{ Square B } \\
\hline 5 & Wk-36135 & $-24.5 \pm 0.2$ & $212 \pm 25$ & $\begin{array}{c}0-8(0.151) \\
151-172(0.469) \\
277-298(0.380)\end{array}$ & \multirow[t]{3}{*}{2} \\
\hline 7 & Wk-36136 & $-24.5 \pm 0.2$ & $95 \pm 25$ & $\begin{array}{c}33-48(0.165) \\
53-74(0.218) \\
79-81(0.017) \\
100-106(0.051) \\
114-136(0.231) \\
225-254(0.317)\end{array}$ & \\
\hline 9 & Wk-36137 & $-25.7 \pm 0.2$ & $142 \pm 25$ & $\begin{array}{c}11-33(0.197) \\
74-99(0.168) \\
106-114(0.055) \\
136-150(0.119) \\
186-225(0.314) \\
254-271(0.149)\end{array}$ & \\
\hline
\end{tabular}




\begin{tabular}{|l|c|c|c|c|c|}
\hline XU & Laboratory code & $\delta^{13}$ C $\% 0$ & ${ }^{14}$ C age BP & Calibrated age BP (68.3\% probability) & Phase \\
\hline 12 & Wk-36138 & $-25.1 \pm 0.2$ & $1299 \pm 25$ & $1186-1205(0.352)$ & $1240-1250(0.140)$ \\
& & & & $1255-1281(0.507)$ & \\
& & & & $1181-1190(0.141)$ \\
& & & & $1198-1214(0.237)$ \\
& & & & $1221-1261(0.622)$ \\
& & & & $1183-1210(0.435)$ & \\
\cline { 1 - 5 } & & & & $1229-1264(0.565)$ & \\
\hline
\end{tabular}

Calibrations undertaken using Calib 7.1 (IntCal13) (Reimer et al. 2013).

Source: Authors' data.

\section{Ochre from the excavations}

Square A XU5 and XU6 revealed two pieces of 'ochre' (Table 13.10; Figure 13.25). Both pieces date to sometime between 4969-5211 cal BP (XU7) and 2882-2955 cal BP (XU5). The small piece of red ochre from XU5 shows evidence of use-wear in the form of two adjacent c. $2 \mathrm{~mm}$ wide longitudinal grooves that extend to the fragment's pointed end. This type of groove is not typically associated with grinding, scoring or rubbing an ochre piece against a surface (Hodgskiss 2010:3347-3356), but may indicate an alternative practice: shaving a piece of ochre with a sharpedged tool (Hodgskiss 2010; Rifkin 2012). We know of no ethnographic records of ochre shaving from Arnhem Land. This ochre piece is mainly composed of haematite $\left(\mathrm{Fe}_{2} \mathrm{O}_{3}\right)$, causing the red colour. Infrared spectroscopy identified also the presence of kaolinite $\left(\mathrm{Al}_{2} \mathrm{Si}_{2} \mathrm{O}_{5}(\mathrm{OH})_{4}\right)$. Raman spectroscopy indicated the presence of minor traces of quartz $\left(\mathrm{SiO}_{2}\right)$ and anatase $\left(\mathrm{TiO}_{2}\right)$.

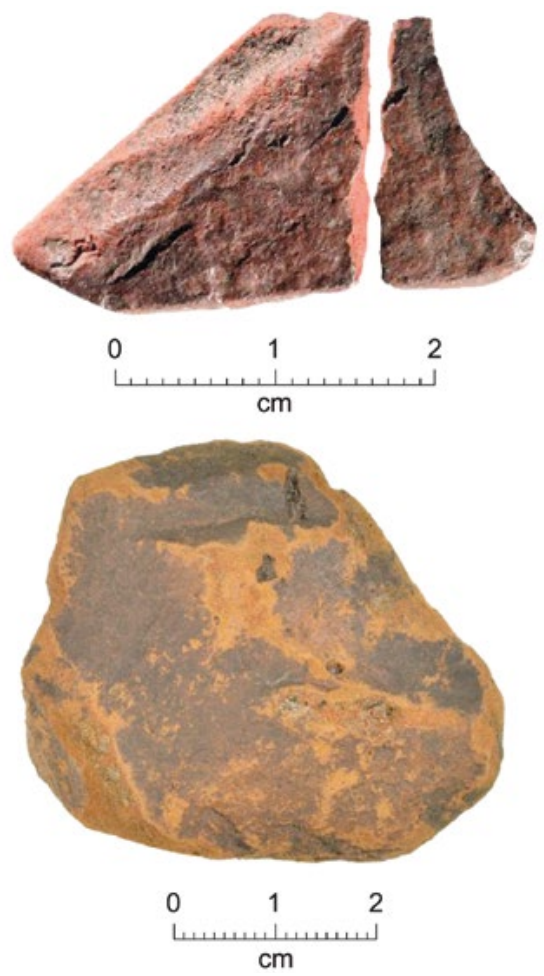

Figure 13.25 Top: Broken piece of red ochre from Square A XU5. Bottom: Piece of yellow 'ochre' from Square A XU6.

Source: Photographs by Steve Morton.
The piece of yellow 'ochre' from XU6 does not show obvious evidence of use-wear, but its soft, powdery surface is not amenable to the preservation of such evidence. This ochre has a much lower percentage of iron than the red ochre, with a relative composition by weight of 28 per cent iron, compared to 84 per cent for the red piece from XU5. The yellow ochre is largely composed of clay, with infrared spectroscopy indicating probable kaolinite. Raman spectroscopy shows peaks typical of iron oxides; however, the particular type of iron oxide could not be identified. The relatively low composition of iron leads to its yellow colour. There is no evidence of goethite or limonite, typical of many yellow ochres. The black covering on this piece showed evidence of the presence of charcoal and quartz, both major components of the deposit. 
The closest visible art to Square A where the ochre fragments were recovered is the red macropod located on the boulder at the edge of the excavation (Figures 13.14, 13.22 and 13.26). The XU5 red ochre fragment dates to shortly after the large boulder with the painted macropod fell into position at the edge of Square A; the ochre fragment could have been used for the painting of the macropod. If this was the case, the macropod painting would date closer to 2882-2955 cal BP than to 4969-5211 cal BP, given the ochre piece's chrono-stratigraphic position in XU5.

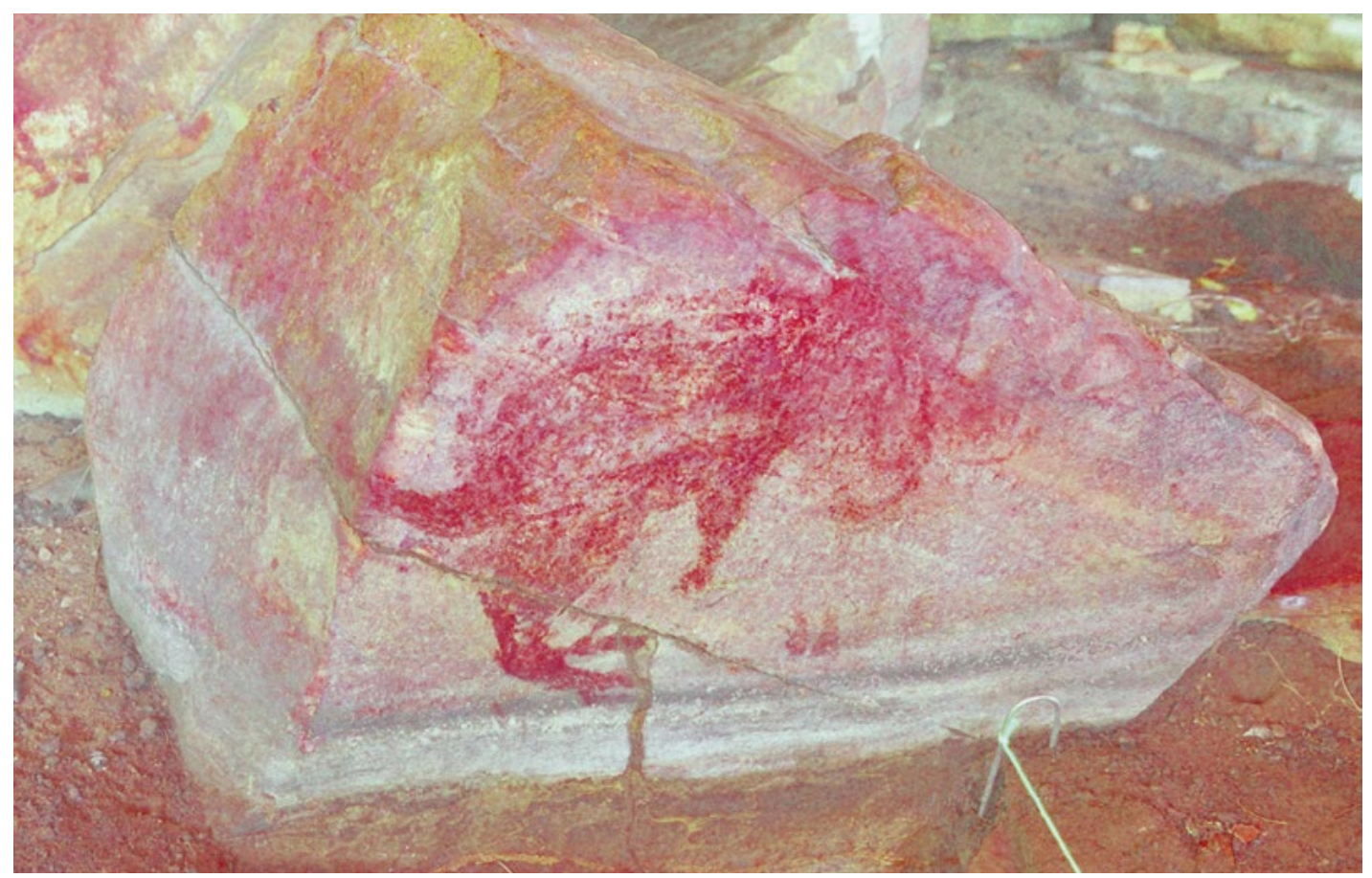

Figure 13.26 Digitally enhanced red-painted macropod on boulder at edge of Square A.

Source: Photograph by Daniel James. DStretch_yrd10 enhancement.

Table 13.10 0chre pieces excavated from Dalakngalarr 1, Square A.

\begin{tabular}{|l|c|c|l|}
\hline XU & Dimensions $(\mathbf{c m})$ & Weight $(\mathbf{g})$ & Munsell colour \\
\hline 5 & $1.48 \times 0.95$ & 0.6 & $7.5 R$ 3/8-7.5R 3/3 dark red/dusky red \\
\hline 6 & $4.85 \times 3.81$ & 36.2 & 10 YR 5/6-10YR 5/8 yellowish brown \\
\hline
\end{tabular}

Source: Authors' data.

\section{Stone artefacts from the excavations}

A total of 1288 stone artefacts - 782 from Square A and 506 from Square B - were recovered from the excavations (Tables 13.5 and 13.8). Other than charcoal, stone artefacts represent by far the most common type of cultural material in the excavations. The stone artefacts were predominantly made on a range of different types of quartzite in both squares and in both phases, followed in quantity by chert, volcanics, siltstone, possibly silcrete and quartz. It is likely that most quartzite artefacts were made on local raw materials, given the natural availability of quartzite in the walls and boulders of Dalakngalarr 1. Local quarrying and production would account for the paucity of cores and presence of cortical flakes in both excavation squares (Stephens 2013). This is consistent with rock walls at Dalakngalarr 1 having been extensively flaked (e.g. Figure 13.27). The few chert artefacts would have been brought in, as chert does not outcrop near the site. 


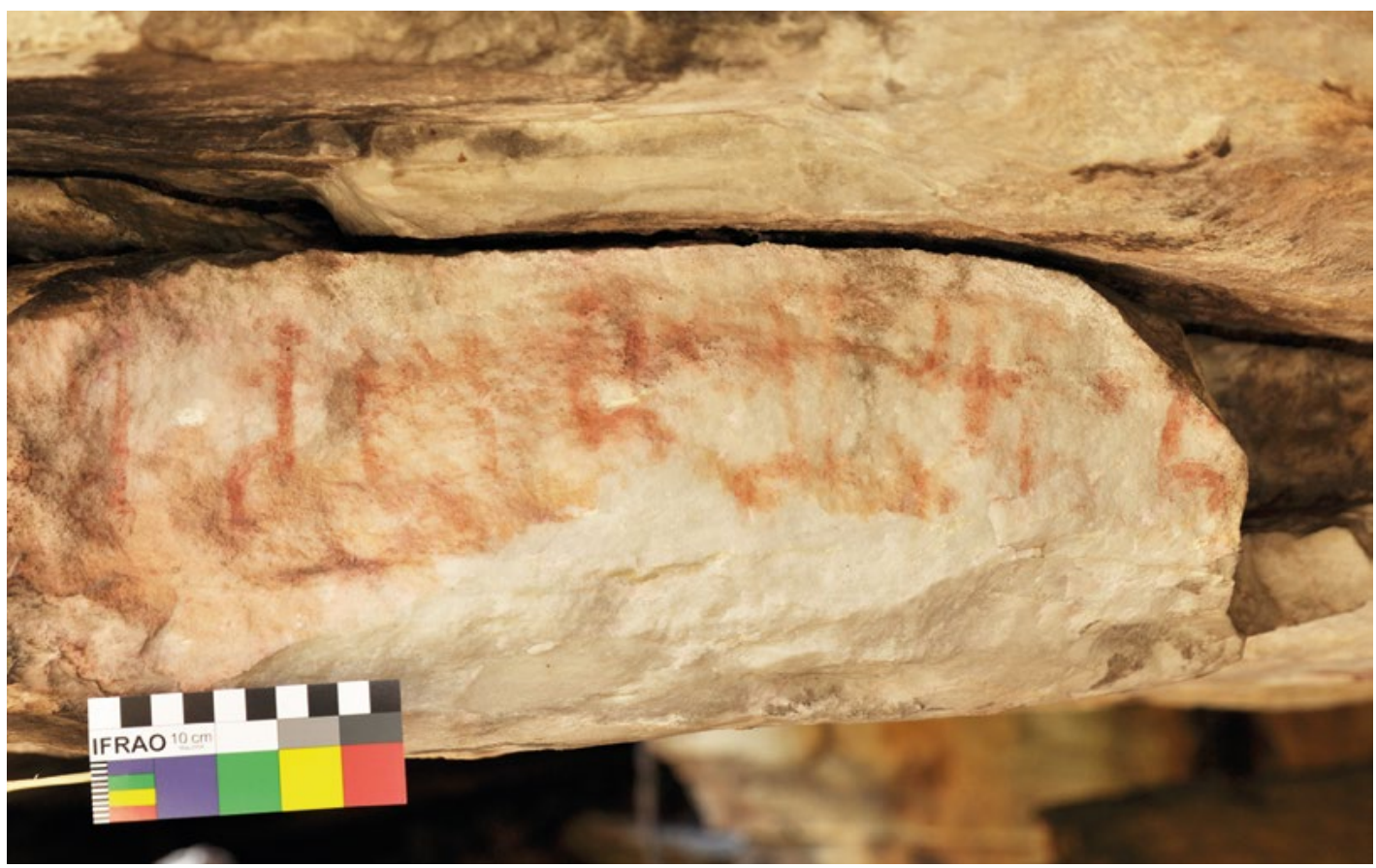

Figure 13.27 Evidence of quarrying at Dalakngalarr 1.5 sale $10 \mathrm{~cm}$.

Source: Photograph by Daniel James.

In both Squares A and B, stone artefact densities peak in Phase 2. In Square A, there are on average 1.8 artefacts/litre of sediment in Phase 1, followed by 42.5 artefacts/litre of sediment in Phase 2, indicating that the early European-contact period of Phase 2 has an artefact density 23.6 times that of Phase 1. Similarly, in Square B there are on average 5.3 artefacts/litre of sediment in Phase 1, followed by 17.7 artefacts/litre of sediment in Phase 2, indicating that during Phase 2 artefact densities were 3.3 times those of Phase 1. These trends represent a consistent increase in intensities of site use as represented by the deposition of stone artefacts. They are consistent with an early European-contact phase of artistic activity across the site.

\section{Bone, paperbark and standing stones}

No bone was recovered from either Squares A or B, probably reflecting the acidic nature of deposits. On the central-western Arnhem Land plateau, bone destruction in acidic deposits primarily affects material older than c. 400 years old, as determined by excavations at Nawarla Gabarnmang (personal observations; cf. Allen and Barton 1989:30; Jones and Johnson 1985:222). The complete and surprising absence of faunal remains from Phase 2 in particular at Dalakngalarr 1 is unlikely to be related to preservation. Did site use not involve the consumption of notable amounts of animal foods during the European-contact period? Or is it simply that the two small excavation squares were positioned in areas not used either for cooking or food discard?

A limited quantity of surface bone, and of paperbark, was observed in other parts of the shelter (Figure 13.28). These remains are in the enclosed and protected southwestern corner of the shelter interior, which also contains a number of small standing stones piled below the opening of a small, narrow cleft that runs between the western outer wall and the shelter's interior (Figures 13.29 and 13.30). Standing stones are known to have been used as burial markers outside clefts in other parts of Jawoyn Country and elsewhere in Arnhem Land (Gunn et al. 2012; see also James in prep.). 


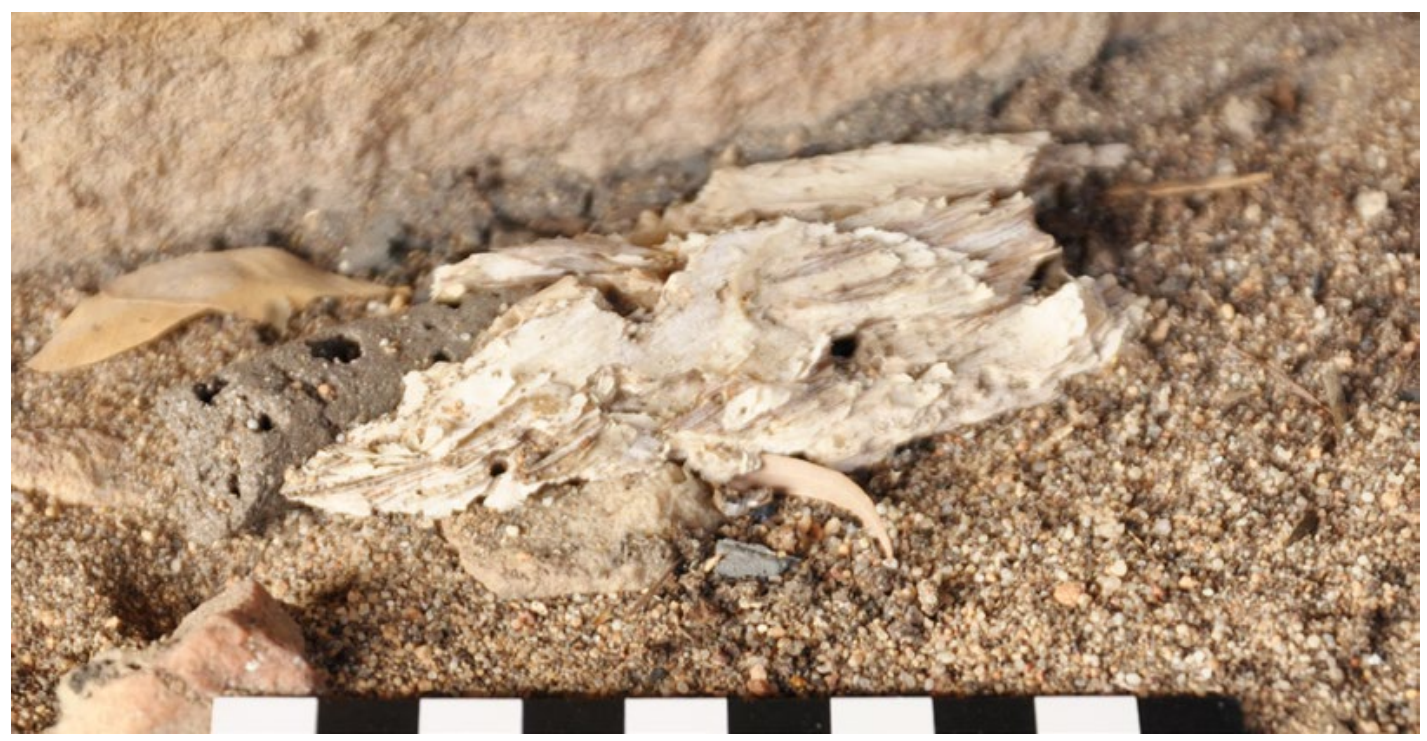

Figure 13.28 Faunal scat (likely echidna) attached to paperbark in the southwestern corner of Dalakngalarr 1.

Echidnas often crawl through paperbark burials (human or dingo) and paperbark pieces caught on their spines are later dislodged. Scale $10 \mathrm{~cm}$.

Source: Photograph by Daniel James.

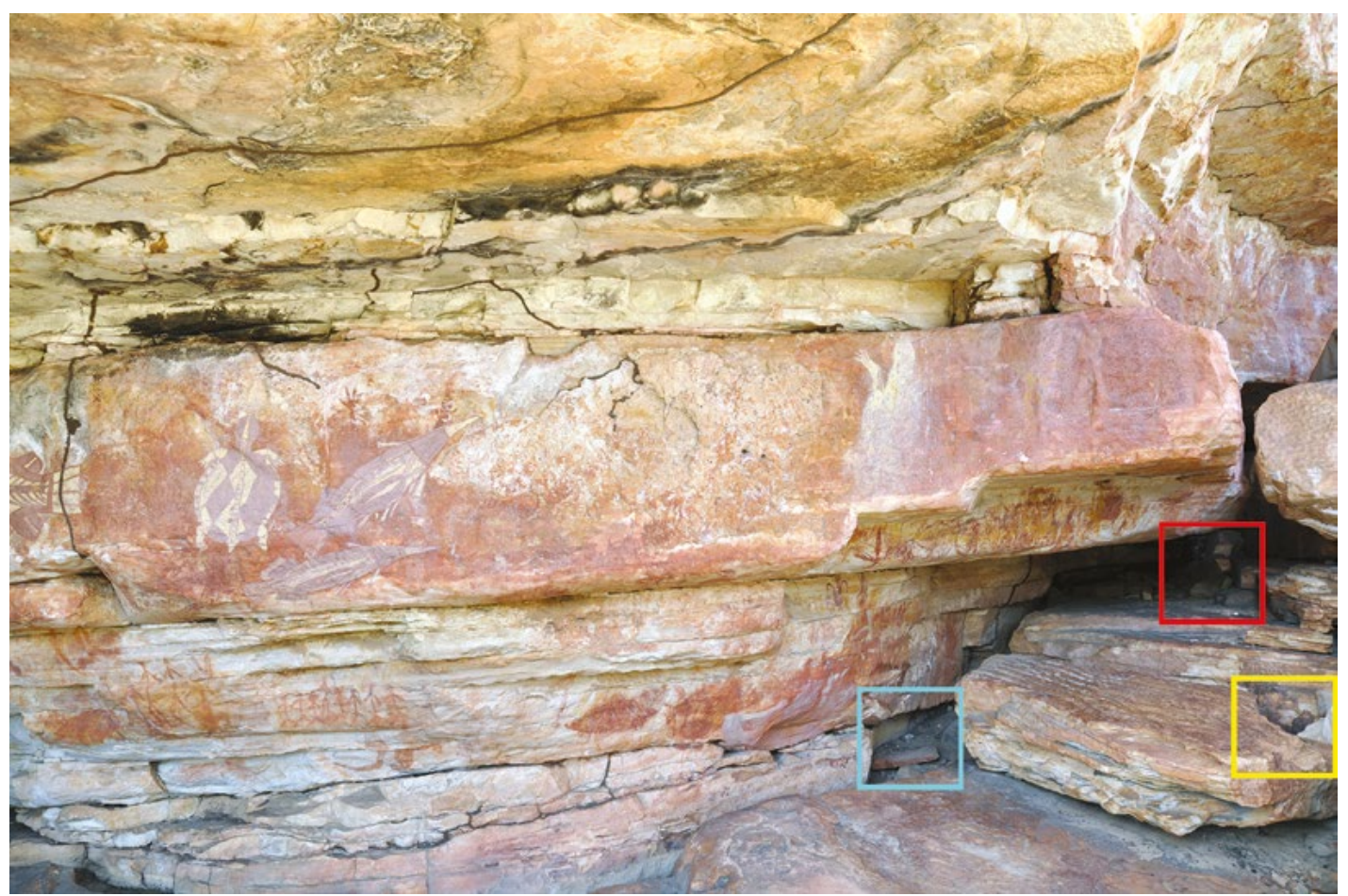

Figure 13.29 Southwestern corner of shelter interior, with cleft indicated by red box, standing stone by yellow box, and location of paperbark by blue box.

Source: Photograph by Daniel james. 


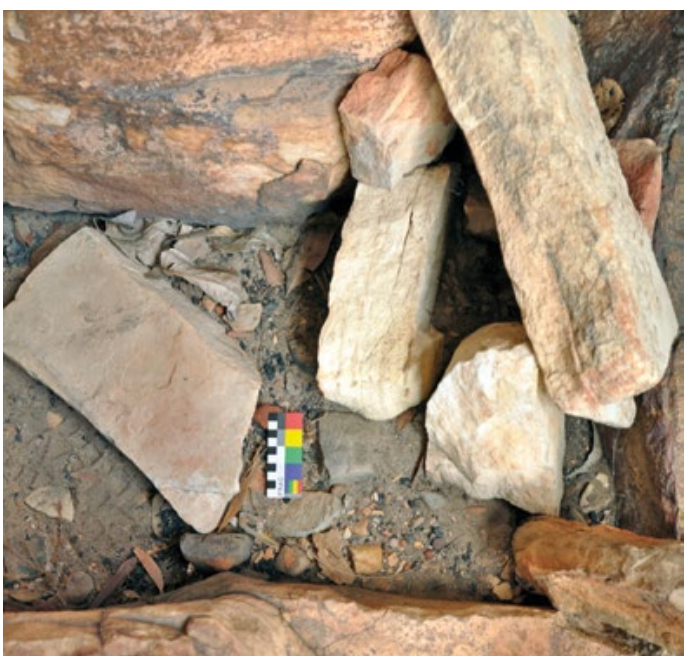

Figure 13.30 Standing stones in southwestern corner of shelter interior, photograph taken from above. Scale $10 \mathrm{~cm}$.

Source: Photograph by Daniel James.

The paperbark by the cleft and the fallen standing stones suggest that this corner of the shelter may once have contained a burial. Human burials have been observed within the Dalakngalarr site complex, further along the escarpment to the southeast of the site (Ray Whear, pers. comm. to Robert Gunn 2012), but their precise location has not been recorded and thus their exact distance from Dalakngalarr 1 is unknown.

\section{Metal artefacts from the excavations}

Three heavily corroded iron objects were excavated from Square A XU2 and XU3 (Figures 13.31A and 13.31B). Radiography (Figure 13.32) revealed that the two pieces from XU2 conjoin and appear to be from a c. $30 \mathrm{~mm}$ long nail, confirmed by the presence of a small 'head' and tapering 'point'. The piece from XU3, too corroded to identify with certainty, appears to be part of another nail. The objects were originally smaller than at present, having 'grown' as corrosion created an accreted outer layer (Selwyn 2004). Hollow sections, observable on the radiograph images, may be a result of manufacture or a by-product of vertical shearing during corrosion (Holly Jones, pers. comm. to Daniel James 2014).
A

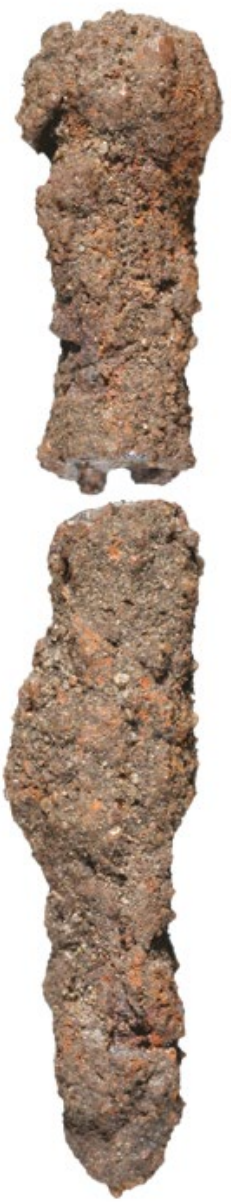

B

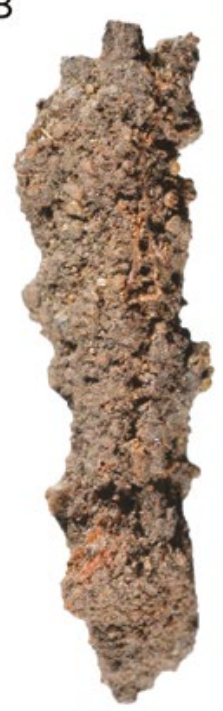

C

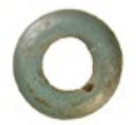

0 1

Figure 13.31 Excavated metal objects and glass bead.

A: Square A XU2; B: Square A XU3; C: Square B XU2.

Source: Photographs by Steve Morton.

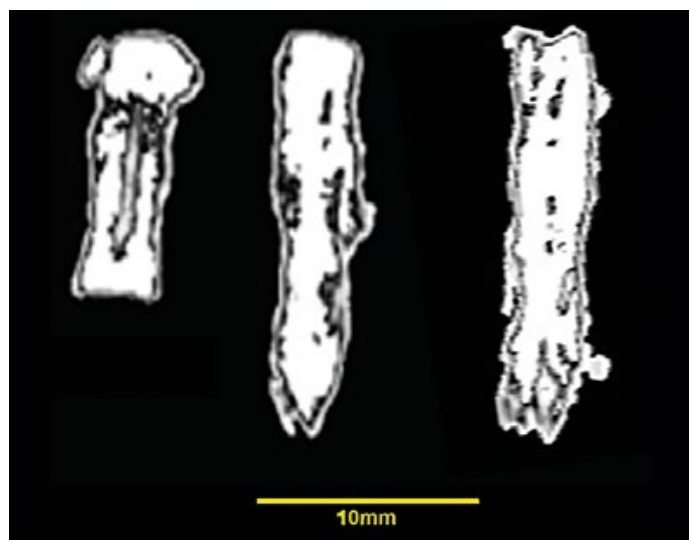

Figure 13.32 Radiograph image of metal objects recovered from Square A XU2 (left, centre) and XU3 (right).

Source: Photographs by Monash University School of Medical Imaging and Radiation Sciences. 


\section{Glass bead from the excavations}

A single glass bead was recovered from Square B XU2 (Figure 13.31C). The bead is blue-green in colour, with an opaque character. It is wider than it is long (width $=2.95 \mathrm{~mm}$ ), its shape a simple, annular form. The central hole is noticeably misshapen on one side, a common trait of wound, annular beads.

A small cavity on the outer bead surface, and the elongated shape and perpendicular position of this cavity relative to the central bead perforation shows this is a 'wound' bead (Harris 1987; Sprague 1985). As the name suggests, these are made by winding molten glass around a metal mandrel to the required size and shape, a costly and labour-intensive method of production. The style of wound bead found at Dalakngalarr 1 is called a 'seed-bead', a general term used to describe small beads of various manufacturing techniques. Beads manufactured this way were typical of Venetian glass bead-making practices, when Venice/Murano dominated the glass bead market by the 18th century. By then, Venetians had established workshops in Holland, France, Moravia and Bohemia (now the Czech Republic) (e.g. Dubin 2006:107; Francis 1991). Similar wound glass beads were also produced in Germany, India and China, and traded within complex networks of exchange over very long distances (cf. Dubin 2006; Francis 1991, 1994; Sprague 1985).

There are few references to the decorative uses of seed beads in Australian archaeology, although there are many instances of glass beads from archaeological sites (e.g. Wesley and Litster 2015). Beads are typically identified as items or currencies of trade. In the most recent discussion of beads in Arnhem Land, Wesley and Litster (2015) examined seed beads in the photographic records of early anthropologists visiting Arnhem Land, and as components of choker necklaces and headbands, a decorative function in body adornment.

The Dalakngalarr 1 bead is only the second to be recovered during excavations in Jawoyn Country. At Nawarla Gabarnmang, a blue glass bead was found in XU1 of excavation Square J (Bruno David, unpublished data), within sediments dating to the early European-contact period.

Glass beads have great potential as markers of cross-cultural contact and Indigenous trade, exchange and mobility in northern Australia. Wesley and Litster (2015) propose that beads were introduced into northern Australia as early as the 18th century by Macassan trepangers. Several bead assemblages from Indigenous sites in the Wellington Range appear to pre-date the first Christian missions established in the region in 1916.

As the Dalakngalarr 1 bead is associated with the latter part of Phase 2 occupation, it likely represents an exchange with members of European exploration parties, missionaries or buffalo shooters probably further to the north, or through interactions after 1880 with non-Indigenous peoples who established early mining and/or pastoral industries further west of Jawoyn lands (Daryl Wesley, pers. comm. to Daniel James 2014). Jawoyn Country is more than $120 \mathrm{~km}$ inland and divided from the coast by a number of territorial-language groups, so the likelihood of an early date and a Macassan source is reduced. A European contact-period age for the bead would be consistent with the iron (nail) pieces recovered from Square A at Dalakngalarr 1, the nearby cut $\log$ and the painted metal axe/hoe motifs (see below).

\section{Paintings of axe/hoes with metal heads and the $\mathrm{X}$-ray art}

Two paintings of axe/hoes with metal heads occur at Dalakngalarr 1 (Figure 13.33), so they must be of the European-contact period. They are done in a style and pigment also otherwise used only for X-ray paintings at the site, always on the rear wall and rear ceiling (e.g. Figure 13.10). Two colours are prominent on both axe/hoes: very pale orange (Munsell 10YR 8/2) was used on the axe painting as infill on the haft and some infill on the blade, and on the hoe painting as solid 
colour throughout; and a distinct iridescent moderate red (Munsell 5R 5/4) was used on the axe painting as linear internal decoration and outlining. Both colours are only found on paintings within the shelter interior rather than on outer rock walls, and they feature prominently on all the X-ray paintings, regardless of subject matter. It seems that the axe/hoe and X-ray paintings were painted with the same materials and surely at much the same time. The iridescent moderate red paint was not used for any other paintings.
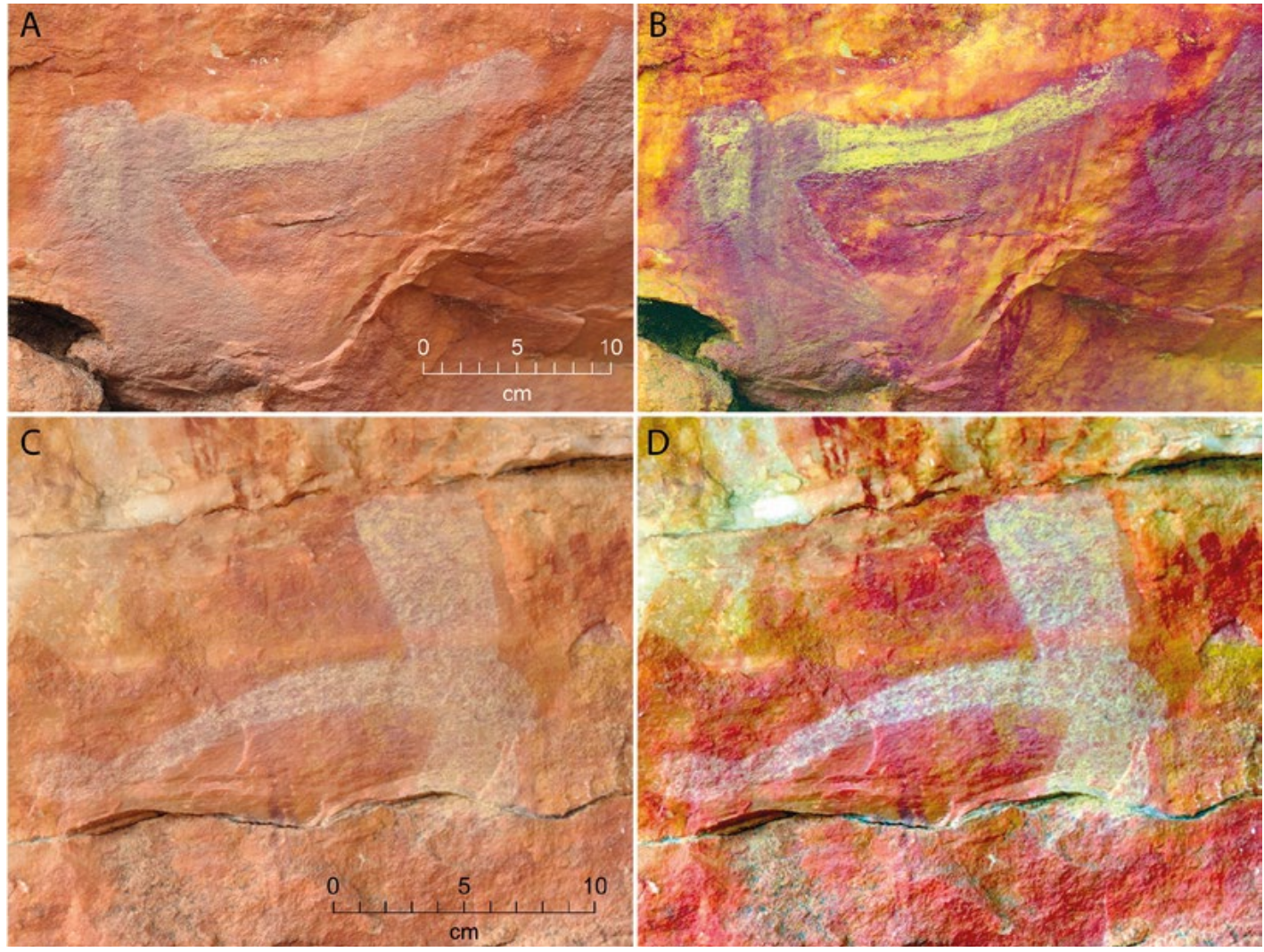

Figure 13.33 Paintings of two axe/hoes with metal heads, Dalakngalarr 1, Panel C1.

A: Axe, original photograph. B. Axe, DStretch_Ids10 enhancement. C: Hoe, original photograph. D: Hoe, DStretch_Ird10 enhancement.

Source: Photographs by Daniel James.

The choice of colour in X-ray art, and in X-ray fish in particular, is important in western Arnhem Land: Taçon (1989a:245-246) recorded ethnographic information across Arnhem Land that emphasised the importance of colour choice and decorative elements as boundaries between life and death, with solid colour paintings depicting fauna that were dead or cooked, with 'the colour roasted out of them'. Internal decorative elements, such as cross-hatching or other linear designs, were 'said to represent the being's flesh and colour and were what gave you "feeling" of Dreamtime essence' (Taçon 1989a:245; see also Taçon 1989b). Colour, particularly vibrant or shimmering colours on fish, may be associated with Bolung (Jawoyn: Rainbow Serpent, a powerful Dreaming being who is both a life-giver and destroyer), as well as qualities of reflection and shimmering, such as found in water and scales (Taçon 1989b). For the Yolngu of northeastern Arnhem Land, red ochre colours are often symbolically linked to blood and ritual power (e.g. Morphy 1992:196).

Infrared spectroscopy of the moderate red pigments on the X-ray paintings at Dalakngalarr 1 has revealed a fairly consistent combination of haematite and kaolinite, indicating a recurring blend of red and white pigments. Various signs point to a late 19th-century or early 20th-century age 
for the moderate red: its occurrence only in the X-ray and the axe/hoe paintings, that all these paintings occur in one part of the site, that they all make the uppermost and most recent layers in superimposition; and that they all have a very 'fresh' appearance.

A major implication of the above observations is that the X-ray art at Dalakngalarr 1 was painted during the same occupational phase as the axe/hoe paintings; that is, during the early Europeancontact period of the late 1800 s or early 1900 s.

\section{Dating the art panels through geomorphology}

Dalakgnalarr 1 occurs along the edge of an extensive rock outcrop rising up to a few tens of metres above a creek c. $100 \mathrm{~m}$ to the north. In this general area, the plain that surrounds the rock outcrop has a low gradient. The creek that drains it subdivides into numerous ill-defined and criss-crossing channels. Here rock stacks demarcate the edge of the outcrop from the surrounding sandy plain. These isolated rock stacks are each a few metres to a few tens of metres in height. The low rising rock outcrop from which the stacks formed has eroded over long geological time scales measured in the millions of years. The base of the outcrop is made up of Marlgowa Sandstone dating to $1740-1780$ million years ago, in the Proterozoic. It consists of hard quartzites that are highly resistant to erosion (see Chapter 10).

Dalakgnalarr 1 is separated from the edge of the rock outcrop by a small seasonal stream that follows a fissure line in the bedrock. A network of narrow fissures parallel to the creek cuts the edge of the outcrop in a criss-crossing checkerboard pattern. The eastern edge of Dalakgnalarr 1 corresponds with one of these north-south fissure lines, whereas the northern edge corresponds with an east-west and transverse fissure (cf. Figures 13.1, 13.2).

The general arrangement of the rock stacks, and the sudden edges of the outcrop, map precisely onto these geological fissures, and it is this same geological configuration that people saw when they first set foot on the Arnhem Land plateau around 50,000 years ago or somewhat earlier. The rich rock art assemblages on the low rise cover, in effect, the pedestals and overhangs of these rock formations on top and on the edge of the rock outcrop.

The site of Dalakgnalarr 1 is typical of rockshelter sites in this part of Arnhem Land: a rockshelter at the edge of rock outcrops, the size of the sheltered area depending on both the mechanical strength of the quartzite bedrock and the fragility of the strata that are more vulnerable to physical and chemical alteration. The decomposition of the weaker sedimentary layers causes the removal of parts of the rock along fissure lines, thereby producing the 'ghost rock' or pillar landscape evident at Nawarla Gabarnmang $17 \mathrm{~km}$ away (cf. Delannoy et al. 2013; see Chapter 10). At Dalakgnalarr 1, the most vulnerable rock strata are D0 and D1 (Figure 13.2). It is from these that the rockshelter we now know as Dalakgnalarr 1 began to take shape: after weathering, the strata D0 and D1 quartz grains that were poorly cemented onto the bedrock were drained away by water action. The creation of an open-ended, sheltered cavity in the rock mass led to a double phenomenon that applies also to the formation of many other rock stacks and rockshelters of this region (see also Chapters 10 and 15):

1. The continued enlargement of voids by chemical alteration and mechanical drainage, causing sections of overhanging ceilings to collapse.

2. As a result of the creation of voids caused by the evacuation of altered rock along one or more sub-horizontal rock strata consisting of less resistant matrix (1 above), the overlying boulder mass compresses the remnant underlying strata to such a degree that it became highly compact and highly resistant to further chemical weathering and drainage. Such underlying remnant strata become the overlying rock mass's pedestal upon which it now balances (Figure 13.34). 

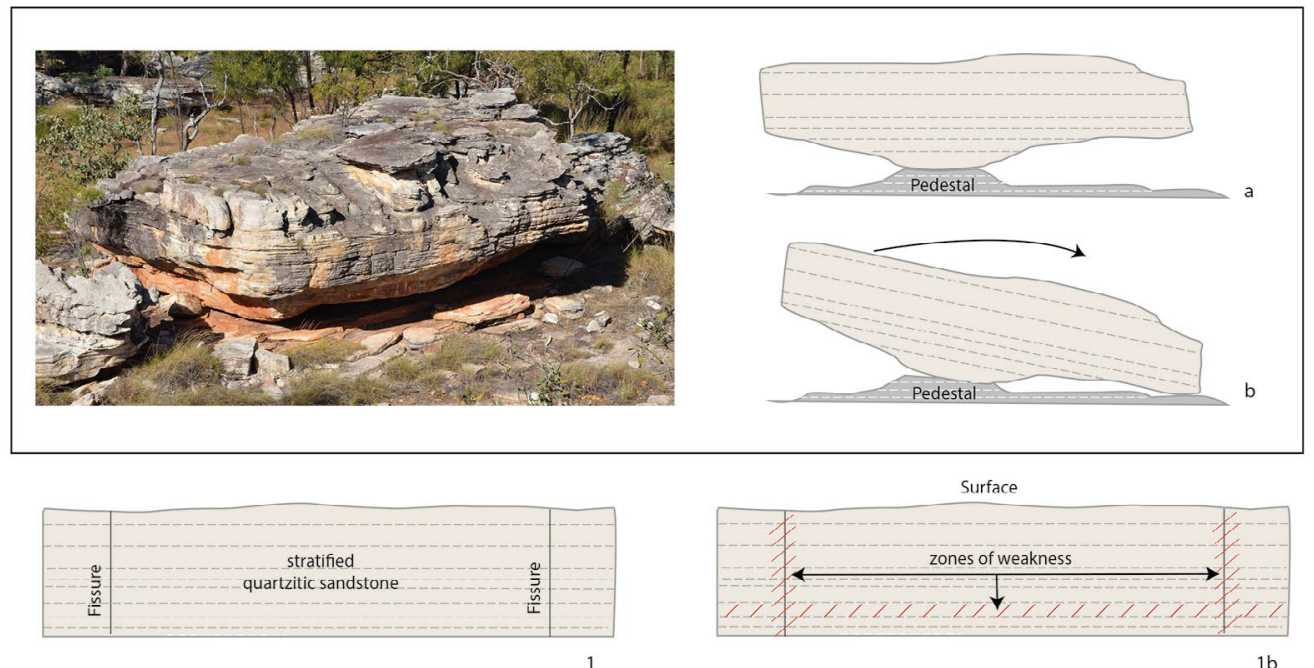

$1 b$
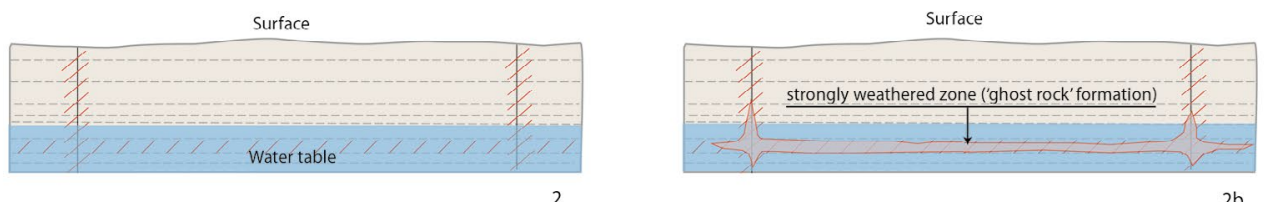

$2 b$
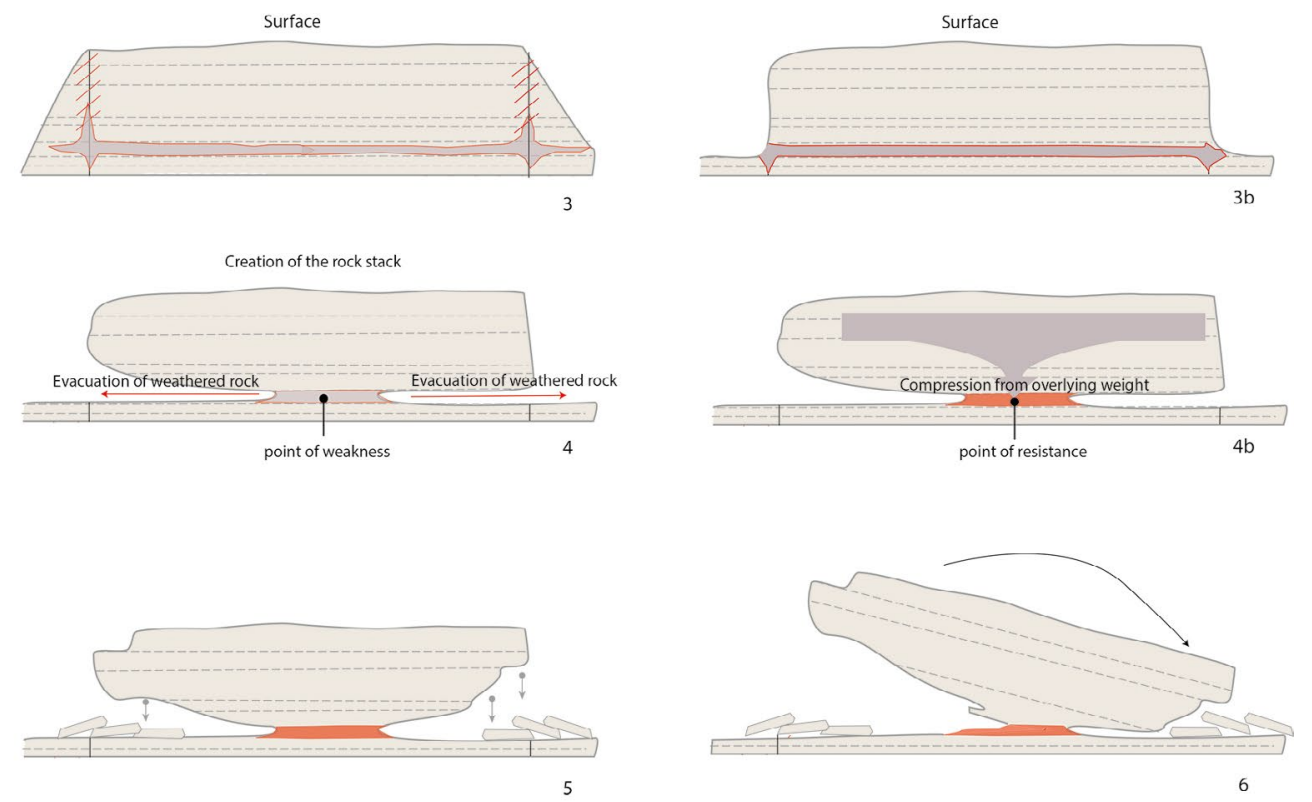

Figure 13.34 Evolution of rock stacks on the Arnhem Land plateau.

Photograph at top shows a typical rock stack from the vicinity of Dalakngalarr. Top right (a): Rock cap over pedestal. Top right (b): Tilted rock cap over pedestal. 1-4: Stages in the creation of the rock stack. 1 and 1b: Stratified sequence of quartzitic sandstone strata, showing vertical fissures and less compacted horizontal strata as zones more susceptible to weathering and erosion. 2 and 2b: Over long periods of geological time typically measured in the millions of years, fissure lines and less compacted strata become preferentially weathered through in the presence of groundwater. This in situ process of weathering, followed by the evacuation of alteration products, is known as 'ghost rock' formation or 'phantomisation'. 3 and 3b: Exposure of rock outcrop due to uplift of the Arnhem Land plateau or to incision by major waterways (e.g. Katherine River). 4 and 4b: The formation of rock stacks. The weathered rock is progressively evacuated (causing 'ghost rock' formations), in the process causing the overlying rock mass (cap) to overhang over its pedestal. The weight of this cap of overlying strata (4b) compresses the underlying pedestal, making it more resistant to further weathering. 5 and 6: Two possible scenarios in the evolution of the most common types of rock stacks in Arnhem Land.

Source: Illustration by Jean-Jacques Delannoy. 
Those strata with the initial voids caused by the chemical alteration and evacuation through water action of decomposed rock are those same remnant strata that constitute the base of rock stacks and of the rockshelter overhangs: the mechanical compression caused by the weight of the overlying rock mass has given strong resistance to those remnant parts of the rock mass that were initially vulnerable to chemical alteration.

This process of rock stack and shelter formation, particularly clear at Dalakgnalarr 1, allows us to frame the age of the rock art.

\section{Geomorphological evolution of the site: Archaeological implications}

The geomorphology of Dalakgnalarr 1 is structured in two different ways:

1. In the northeast, it is a large rockshelter of nearly $10 \mathrm{~m}$ depth with a low, extensively painted ceiling of $0.8 \mathrm{~m}$ to $1.8 \mathrm{~m}$ height. The ground level is cluttered with numerous blocks fallen from the ceiling.

2. In the southwest, the rockshelter becomes much narrower (maximum $3 \mathrm{~m}$ wide) and higher (1.8 $\mathrm{m}$ to $2.5 \mathrm{~m}$ high). It is bordered by a clutter of superimposed and overlapping blocks that slope towards the northwest, and separated from the rock stack's base strata by a deep and narrow corridor.

This two-fold layout was caused by differential geomorphological evolution, although both are subject to the same processes of rock collapse.

After the main chamber at the northeast section of the site had been created by weathering and drainage of strata D0-D1, the large, sheltered area under the overhang attained its particular morphology through the collapse of sections of ceiling strata (Figure 13.35). The geomorphological and archaeological evidence from the excavations suggest five major phases in the rockshelter's formation.

Drainage of the chemically weakened strata D0-D1 sediments, and continued expansion of this void through further chemical alteration and drainage, result in the formation of an initial cavity sheltered by overhanging strata D3 to D22 above it. Mechanical relaxation of parts of the rock structure, caused by the absence of underlying support, together with gravity, cause sections of the overhanging strata D2-D3 to collapse. The geophysical data (Figure 13.11) indicate the presence of a flat surface rock underneath an overlying clutter of fallen blocks. This flat rock could either be bedrock or an underlying collapsed rock slab that fell flat onto the ground from a shallow height given that the ceiling would only have been c. 50 to $60 \mathrm{~cm}$ above, as indicated by the thickness of the evacuated strata D0 and D1.

A process of gravitational readjustment then took effect with sections of the new stratum D4 ceiling collapsing, deepening the rockshelter southward in the process: a collapsed section of stratum D4 now forms the angular blocks revealed in the lower levels of the Square A excavation. The radiocarbon dating results from Square A indicate that the collapse of stratum D4 is older than $4431 \pm 25 \mathrm{BP}(4969-5211 \mathrm{cal} \mathrm{BP})$, as the charcoal sample came from between fallen blocks rather than from immediately underlying deposits. A new phase of rock collapse subsequently took place, simultaneously affecting both the front and rear of the shelter. Here, part of stratum D2 fell near the back of the shelter, while part of stratum D5 fell near the entrance. This is today evident at ground level by the presence of large, superimposed blocks arranged step-wise and inclined towards the north. Given this sequence of events, the artworks on the ceiling rock surfaces newly created by this last phase of rockfall must be later in age than the age of the stratum D5 (front of site) and stratum 
D2 (rear of site) rockfall events. The artworks located in the middle section of the site (dating to after the collapse of stratum D4) can themselves be older, but not older than 4969-5211 cal BP, given the age of the stratum D4 blocks found at the base of Square A.

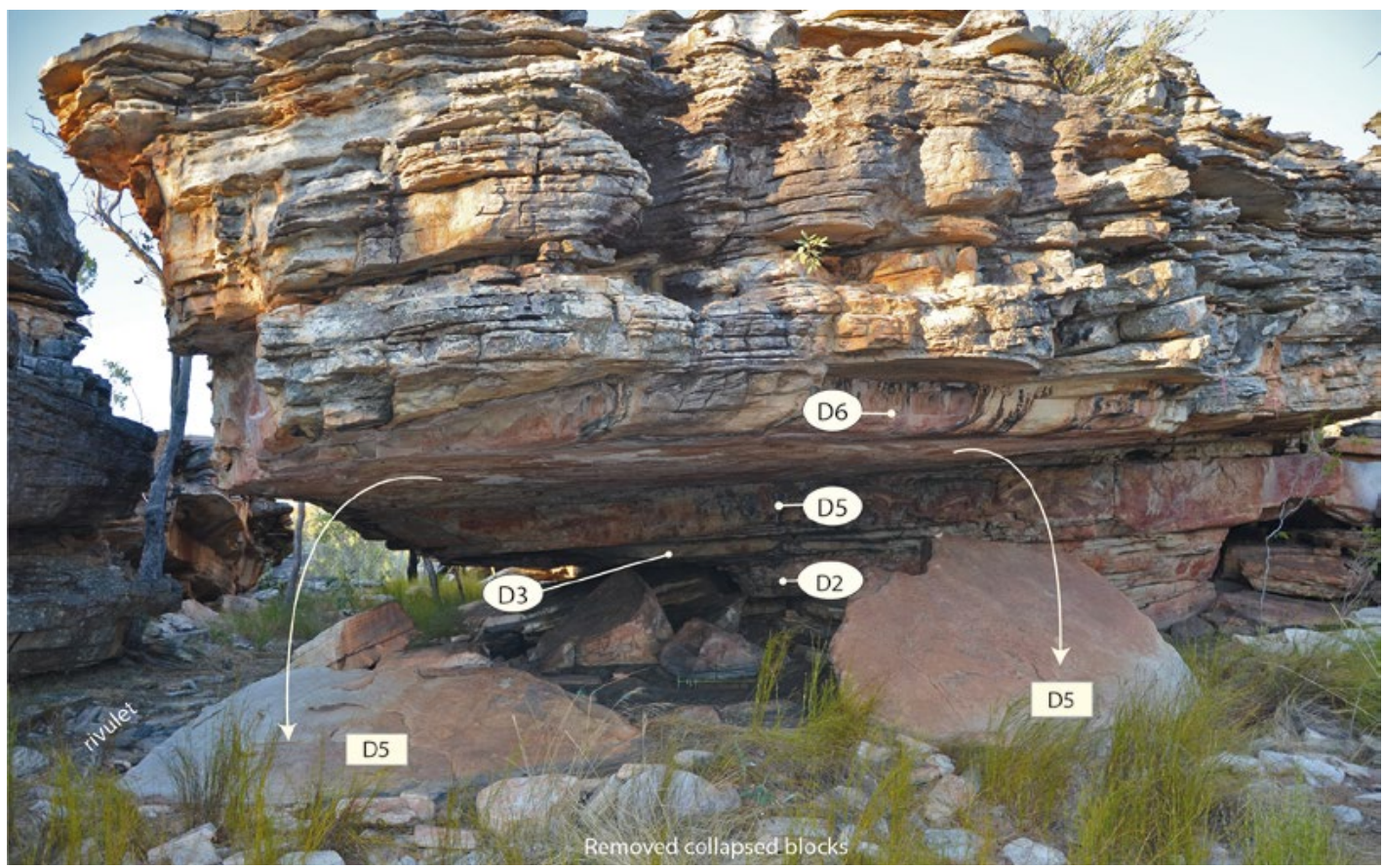

Figure 13.35 Northwestern section of Dalakngalarr 1, showing the different rock strata referred to in the geomorphological discussion.

Source: Illustration by Jean-Jacques Delannoy.

On the northern side of the shelter are found numerous blocks that appear from their location below the edge of the overhang to have originated from the overlying rock cap. However, the blocks' regular layout and relatively stable configurations suggests that they have been repositioned along this edge of the site. Petrographic analysis and the relative positioning of the rock strata from which these blocks came indicate that they came from within the rockshelter. Together, the presence of unusually open spaces within the sheltered space, and repositioned blocks at the northern edge of the overhang, indicate clearance of rock clutter at ground level. That cleared space cannot be explained by natural erosion of fallen blocks, as erosion of the hard quartzites that make up the rock stack's strata took place over very long geological time scales measured in hundreds of thousands of years; this is not consistent with the much shorter, c. 5000 years for the roof-fall indicated by the archaeological excavations. We can only conclude that the space within the site has been reworked by people in the past.

The southwest section of the site has witnessed a different evolution from that of the north, although here too roof-fall was prominent. In the southwest of the site, a section of the wall became detached from the parent rock mass (Figure 13.36). This detachment created the narrow corridor between the parent rock and the now-detached balancing rocks (cross-section $\mathrm{C}-\mathrm{D}$ on Figure 13.2). The detachment of rock slabs - and associated creation of the narrow corridor - appears to be very old, resulting in the stack of balancing rocks in adjacent areas to the northwest. The stepped arrangement of the superimposing slabs was caused by the slipping of slabs, rock stratum by rock stratum. The most elevated strata in this rock stratigraphy are those located furthest from the edge of the parent rock wall. This process of detachment and stacked accumulation at ground level enables ready access (e.g. for painting) to elevated ceiling surfaces. Accordingly, large sections of the back wall spanning from the base of the corridor to the ceiling 
are covered by artworks. It is likely that the oldest artworks are found in this part of the site, because here the corridor and associated stacked detached slabs formed prior to the extant rock surfaces in the northeastern sections of the shelter.

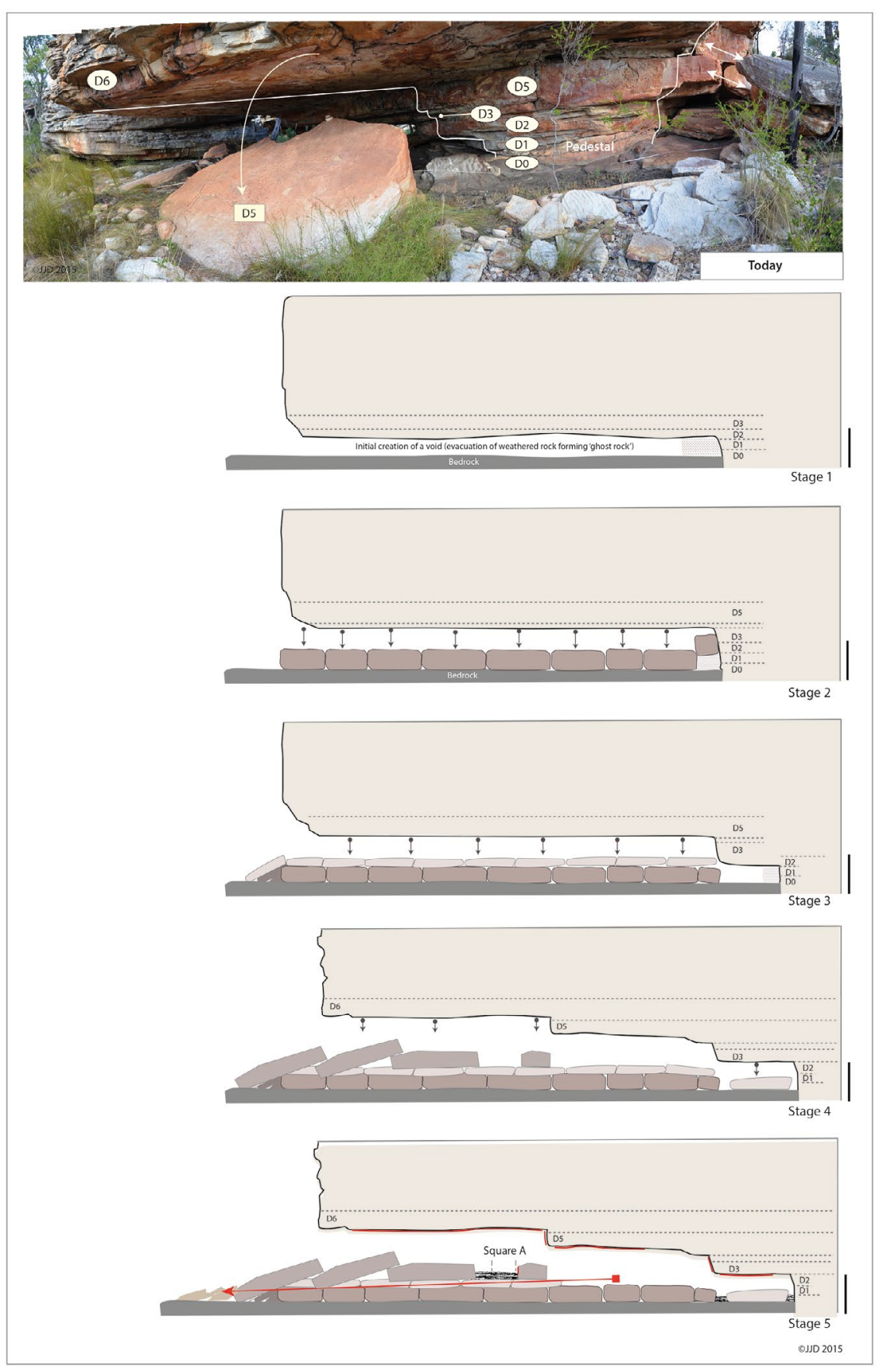

\section{Figure 13.36 Geomorphological evolution of Dalakngalarr 1.}

Stage 1: Evacuation of strata D0 and D1, previously heavily weathered over long geological time scales (see Figure 13.34). Stage 2: Collapse of stratum D3. The low height of the roof above the ground causes the blocks to fall flat onto the bedrock. Stage 3: New phase of roof-fall (D4) and evacuation of weathered materials from distal parts of strata D0 and D1 (at the back of the overhang). Stage 4: Roof-fall takes place along the front section of stratum D5 and the back section of stratum D3. Stage 5: Human occupation at the site causes the build-up of archaeological deposits at ground level, and creates artworks on rock surfaces. It is during these periods of occupation that collapsed blocks are removed from the sheltered area to areas outside the dripline.

Source: Illustration by Jean-Jacques Delannoy. 


\section{Dating the beeswax art}

Four examples of beeswax art have been recorded from Dalakngalarr 1 and directly radiocarbon dated (Table 13.11). Beeswax art must have been created soon after the beeswax was collected, as it quickly becomes brittle and unusable for rock art.

Table 13.11 Radiocarbon dates on the beeswax art of Dalakngalarr 1.

\begin{tabular}{|l|c|c|c|c|}
\hline Sample \# & Laboratory code & $\delta^{13}$ C\% & ${ }^{14}$ C age BP & Calibrated age BP (68.3\% probability) \\
\hline Beeswax Image 1 & Wk-35509 & $-21.9 \pm 0.2$ & $409 \pm 25$ & $471-507(1.000)$ \\
\hline Beeswax Image 2 & Wk-35510 & $-23.6 \pm 0.2$ & $367 \pm 25$ & $332-356(0.305)$ \\
& & & & $433-489(0.695)$ \\
\hline Beeswax Image 3 & Wk-35511 & $-25.8 \pm 0.2$ & $117 \pm 25$ & $25-39(0.115)$ \\
& & & & $63-118(0.489)$ \\
& & & & $123-140(0.140)$ \\
& & & & $221-232(0.095)$ \\
& & & & $242-260(0.160)$ \\
\hline Beeswax Image 4 & Wk-35512 & $-25.2 \pm 0.2$ & $1870 \pm 25$ & $1741-1755(0.131)$ \\
& & & & $1782-1796(0.113)$ \\
& & & & $1807-1867(0.756)$ \\
\hline
\end{tabular}

Calibrations undertaken using Calib 7.1 (IntCal13) (Reimer et al. 2013).

Source: Authors' data.

\section{Beeswax Figure 1}

This figure, located on the ceiling toward the centre of the shelter interior (Figures 13.37 and 13.38), is a star-shaped geometric design superimposed over two paintings. The beeswax has been AMS radiocarbon dated to $409 \pm 25$ BP (Wk-35509), which calibrates to 471-507 cal BP (with a median probability of 487 cal BP) (Table 13.11). So, the two paintings underneath Beeswax Figure 1 are of this age or older (Figure 13.37):

1. A small, solid-white macropod (Figures 13.38, 13.39 image \#406).

2. An indeterminate solid-red painting (Figures 13.38, 13.39 image \#460).

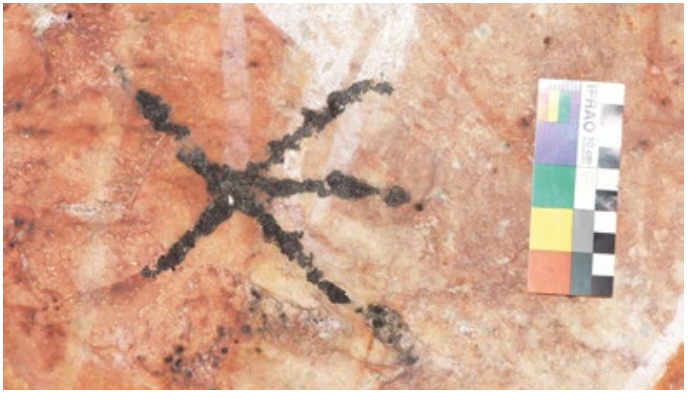

Figure 13.37 Beeswax Figure 1. Scale $10 \mathrm{~cm}$. Source: Photograph by Daniel James.

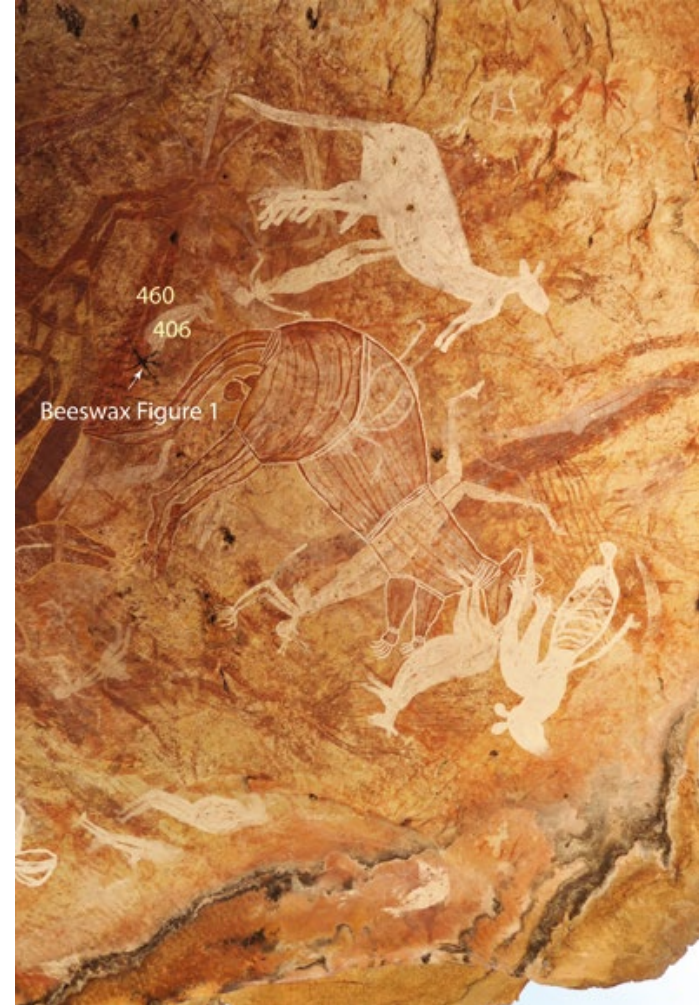

Figure 13.38 Ceiling panel showing location of Beeswax Figure 1 (in box) and picture numbers from Harris Matrix.

Source: Photograph by Daniel James. 


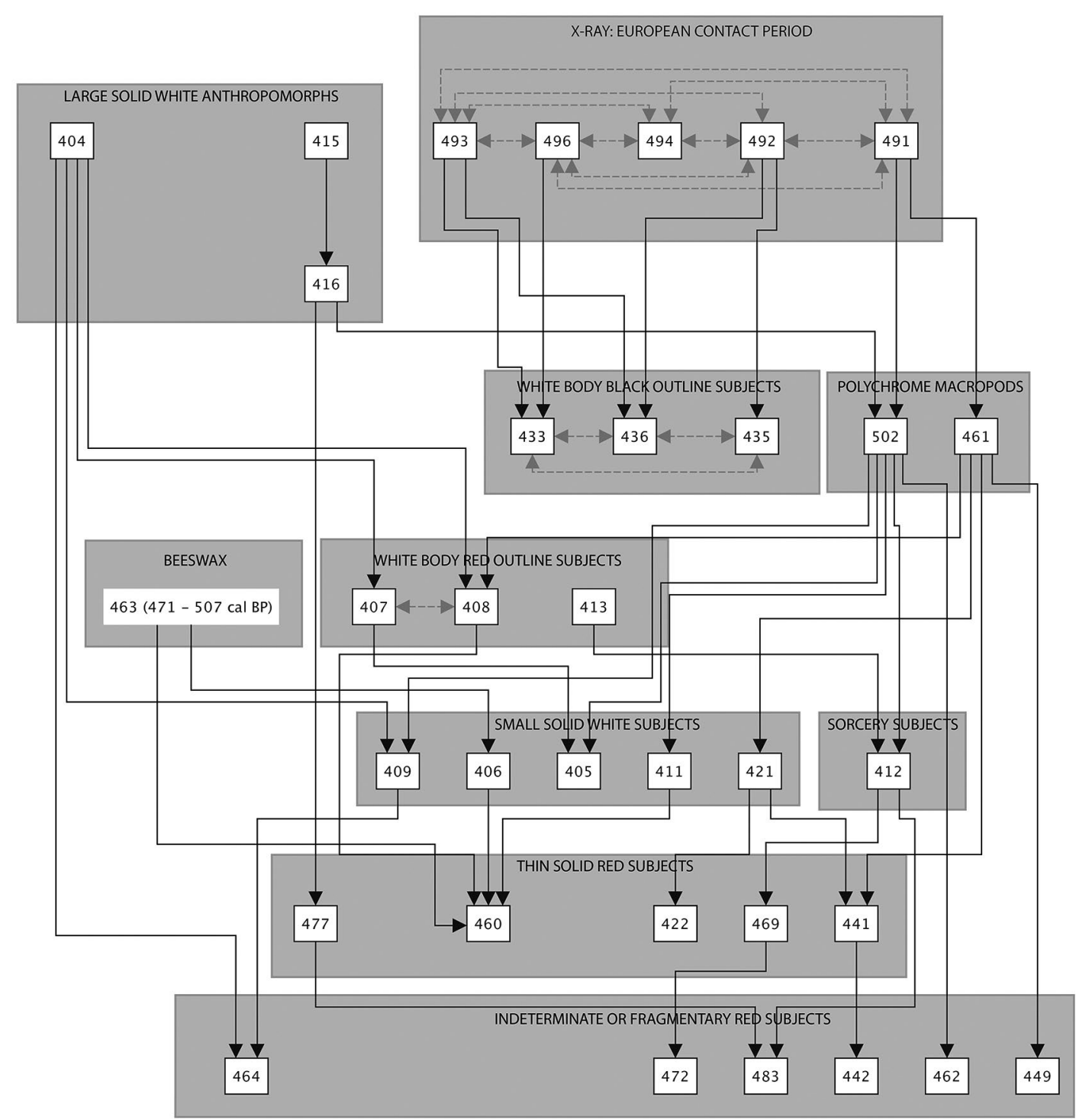

Figure 13.39 Harris Matrix showing chrono-stratigraphic relationship of images for painted ceiling at Dalakngalarr 1.

Note: Descriptive designations for images (e.g. 'Large solid white anthropomorphs', 'Sorcery subjects') are further elaborated in James in prep.

Source: Illustration by Daniel James.

\section{Beeswax Figure 2}

This figure, on the ceiling's flat, horizontal overhang a short distance from the rear wall of the shelter, consists of a nodule of beeswax superimposed by a red male anthropomorph with a macropod/bird foot (Figures 13.40-13.42). The macropod/bird-footed anthropomorph is unlike the macropod-footed anthropomorph found near Beeswax Figure 1. This one is not depicted in contorted perspective (compare Figures 13.40 and 13.43), arms and hand are sloped downwards, a penis is evident and the feet are shown in twisted perspective. But, like the other one, one foot appears to be human-shaped, the other either macropod or bird-like in shape. These similarities suggest that both paintings express a common system of meaning relating to Spirit-Beings and Dalakngalarr 1's repeated locational meaningfulness. 
The radiocarbon date for Beeswax Figure 2 is $367 \pm 25 \mathrm{BP}$ (Wk-35510), which calibrates to $332-489$ cal BP (with a median probability of 437 cal BP; Table 13.11); the macropod/birdfooted being must be of similar age or younger.

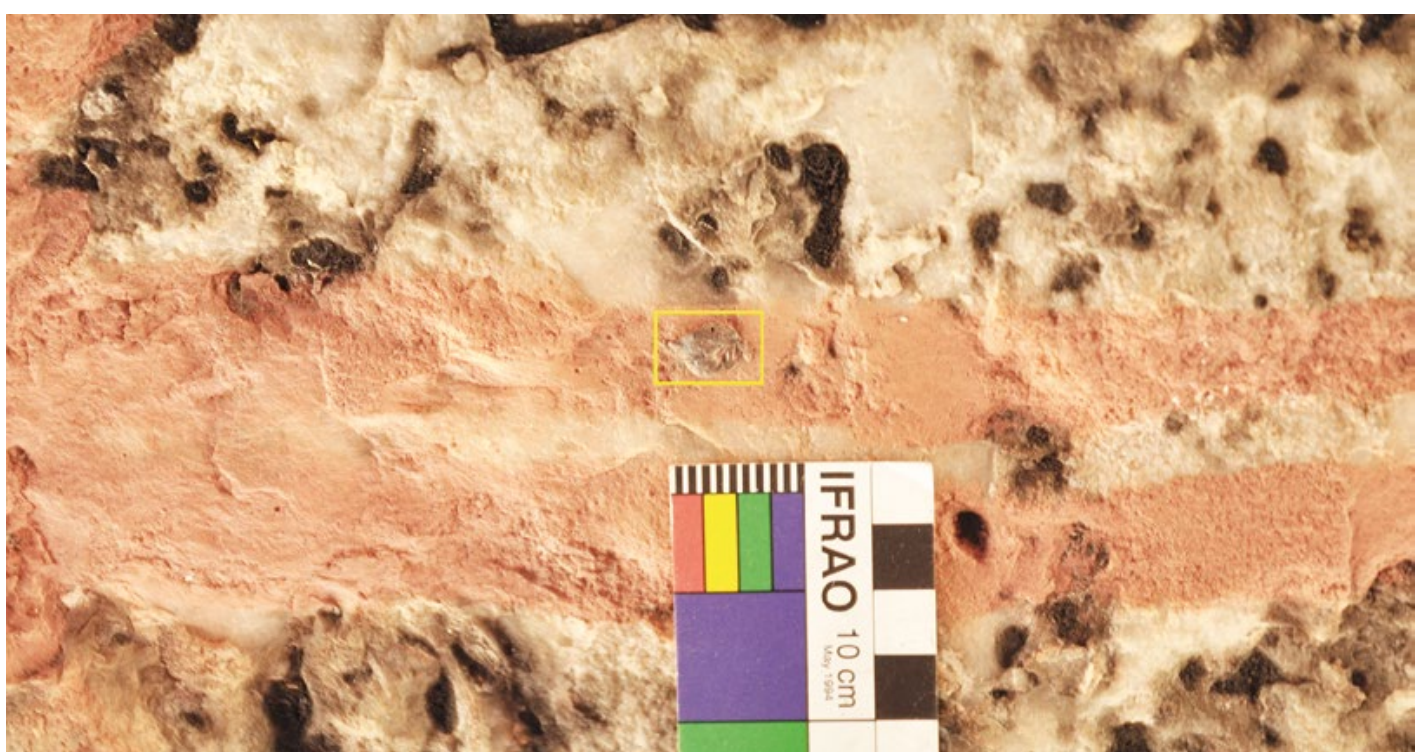

Figure 13.40 Location of Beeswax Figure 2 (yellow box). Visible portion of scale, $1 \mathrm{~cm}$ per black or white square.

Source: Photograph by Daniel james.

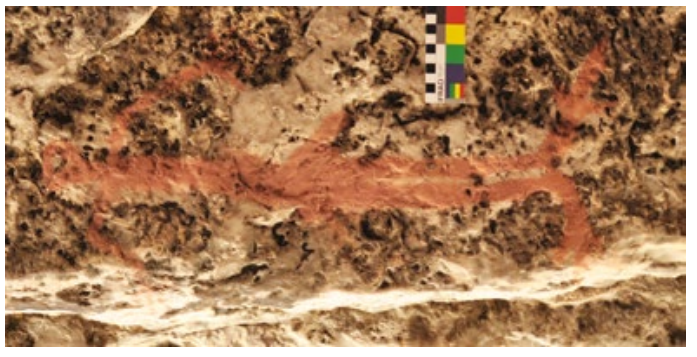

Figure 13.41 Red macropod/bird-footed anthropomorph superimposing Beeswax Figure 2, Panel $\mathrm{C} 18$.

Source: Photograph by Daniel James.

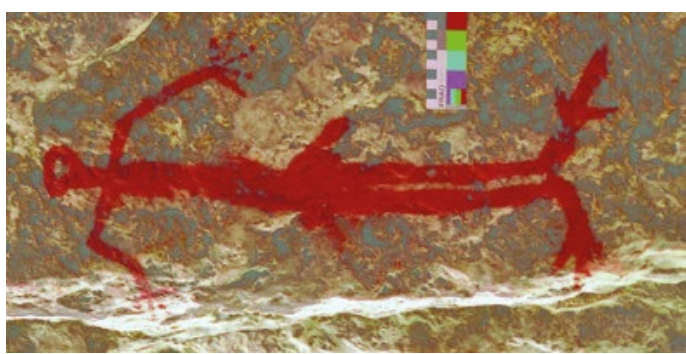

Figure 13.42 Red macropod/bird-footed anthropomorph beneath Beeswax Figure 2, Panel C18, after DStretch_yrd10 enhancement. Scale $10 \mathrm{~cm}$.

Source: Photograph and enhancement by Daniel James.

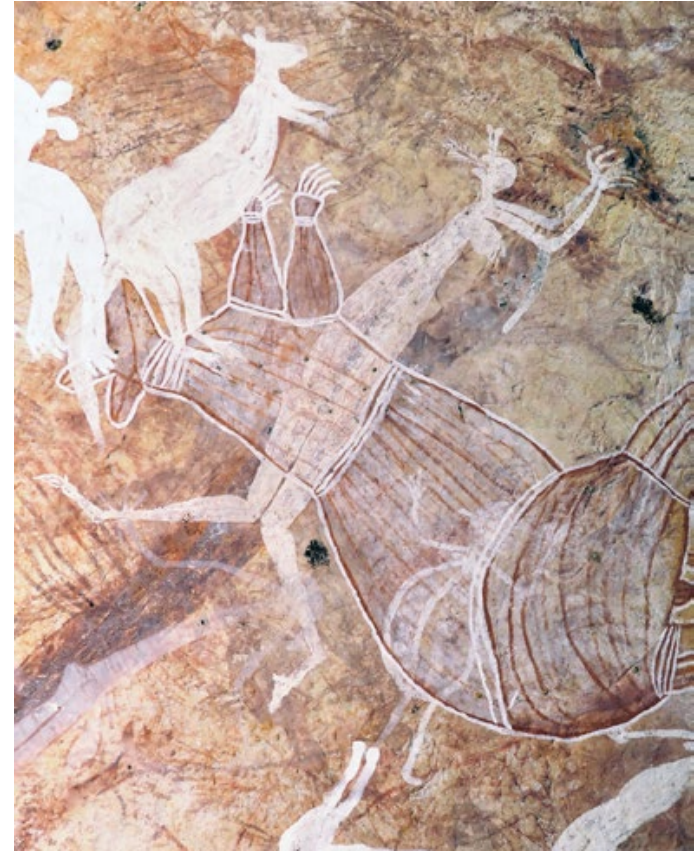

Figure 13.43 Macropod-footed female anthropomorph on ceiling panel that contains Beeswax Figure 1.

Source: Photograph by Daniel James. 


\section{Beeswax Figure 3}

This piece of beeswax is found on the rear wall in the southwestern corner of the shelter, on the topmost vertical surface. It is a small nodule of beeswax that had, at the time of recording, partially lifted off the rock surface (Figures 13.44 and 13.45). No paintings are evident under it. This beeswax nodule dates to $117 \pm 25 \mathrm{BP}$ (Wk-35511), which calibrates to 25-260 cal BP with a median probability of $115 \mathrm{cal} \mathrm{BP}$.

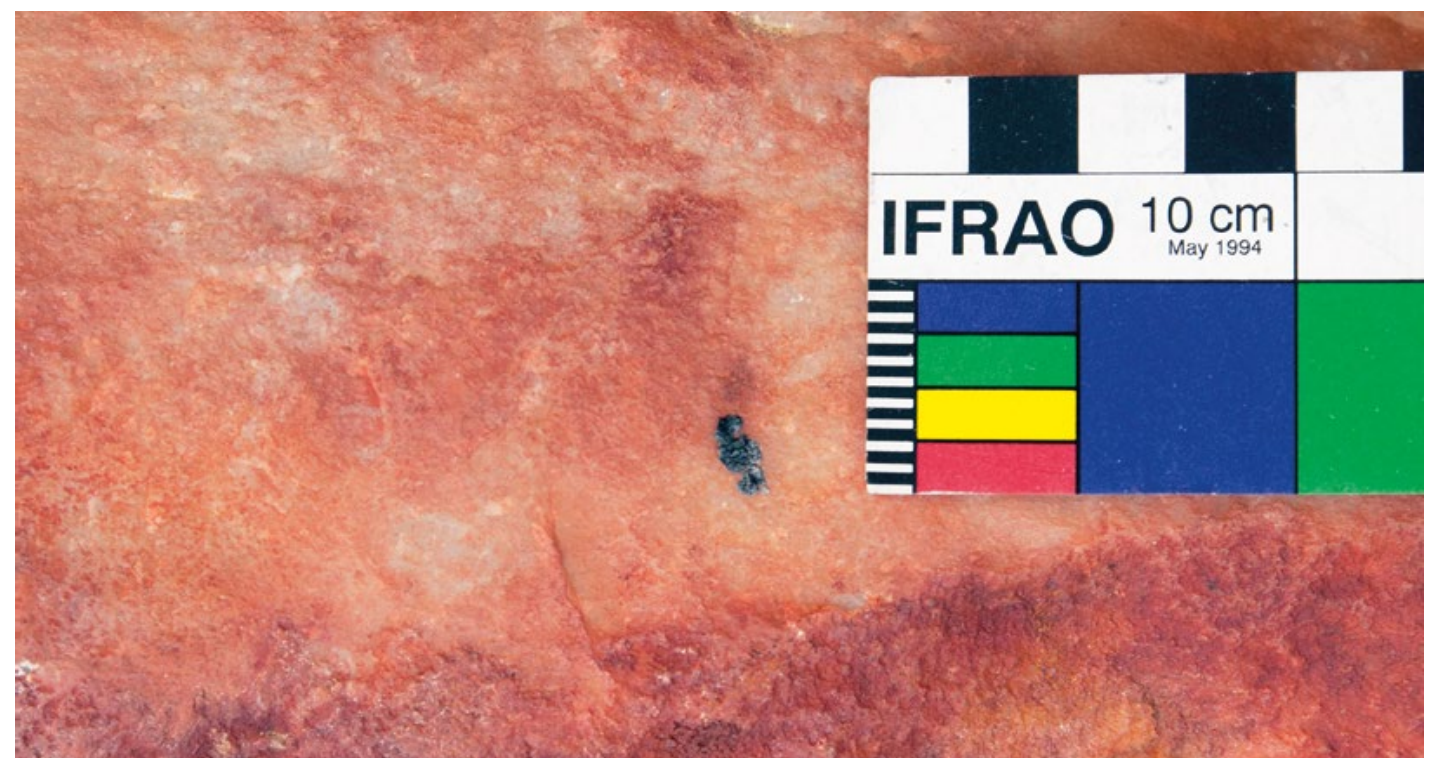

Figure 13.44 Close-up of Beeswax Figure 3. Scale units in $1 \mathrm{~cm}$ white or black squares.

Source: Photograph by Daniel James.

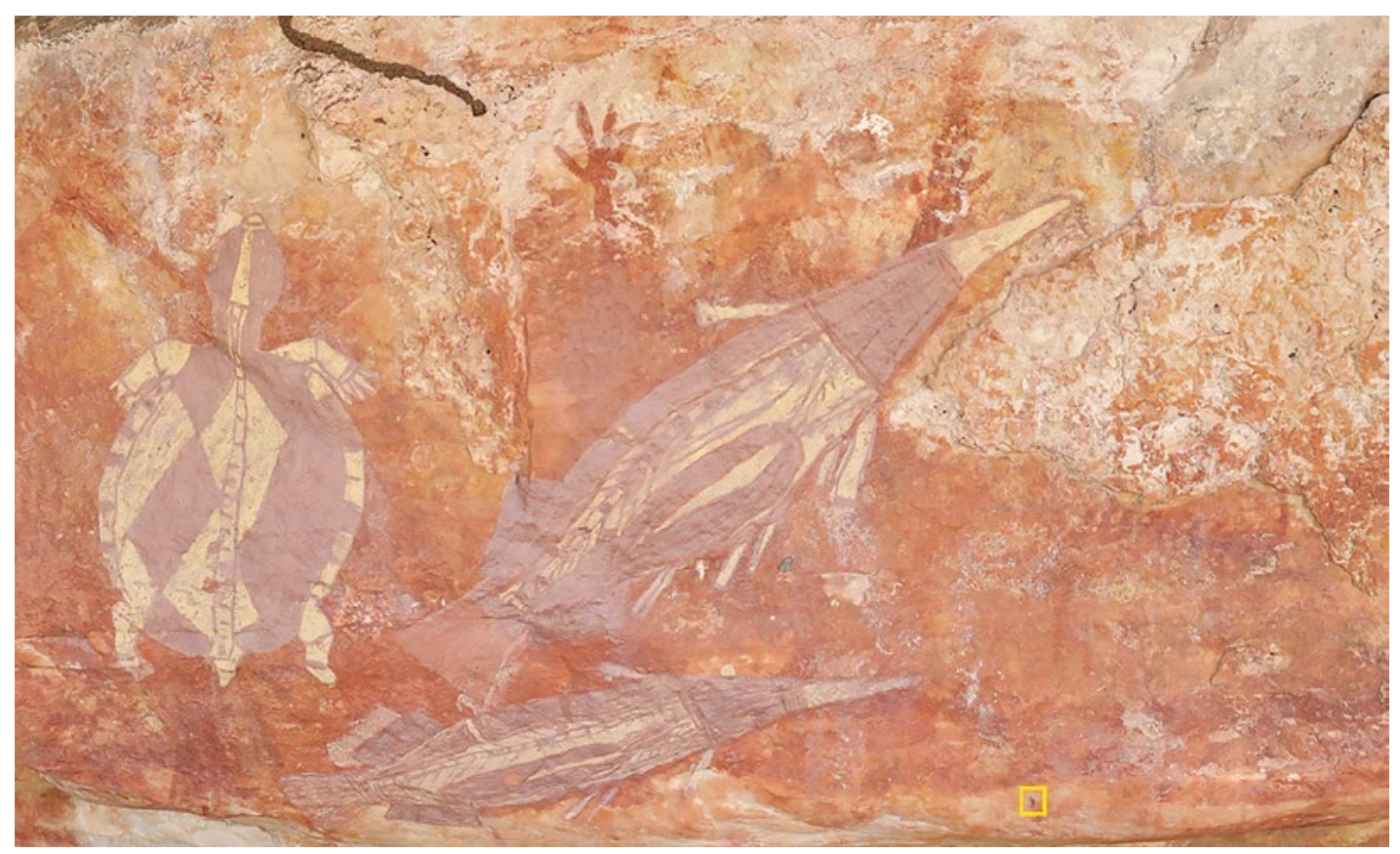

Figure 13.45 Location of Beeswax Figure 3, in small yellow square near bottom right.

Source: Photograph by Daniel James. 


\section{Beeswax Figure 4}

This small amorphous piece of beeswax is located on a small, overhanging rock surface towards the southwestern corner of the shelter, where rock art is generally poorly preserved. It superimposes very faded indeterminate traces of red pigment (Figures 13.46-13.48). A radiocarbon date of $1870 \pm 25$ BP (Wk-35512) for the beeswax gives a calibrated age of 1741-1867 cal BP with a median probability of $1817 \mathrm{cal}$ BP (Table 13.11). The underlying faded red paintings are of a similar age or older.

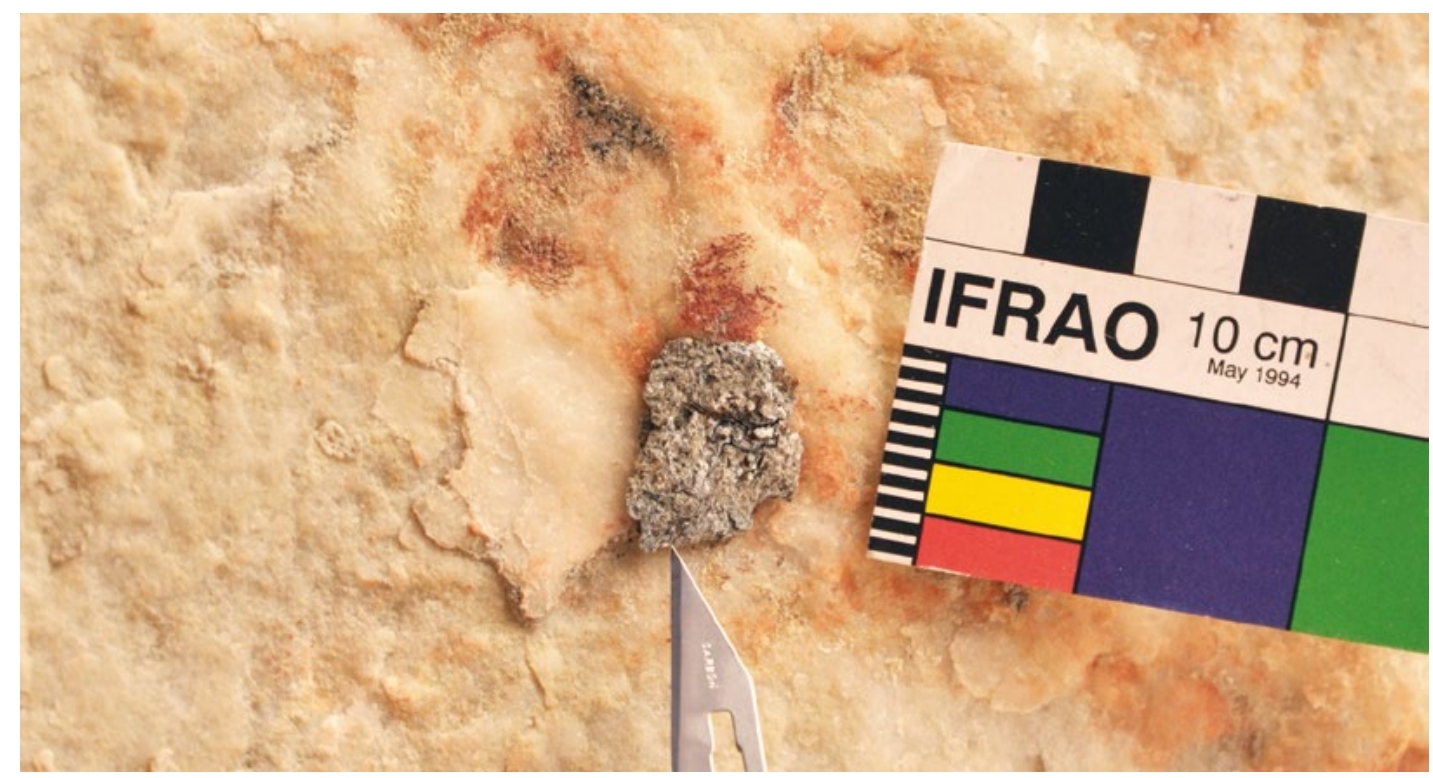

Figure 13.46 Close-up photograph of Beeswax Figure 4. Scale units in $1 \mathrm{~cm}$ squares.

Source: Photograph by Daniel James.

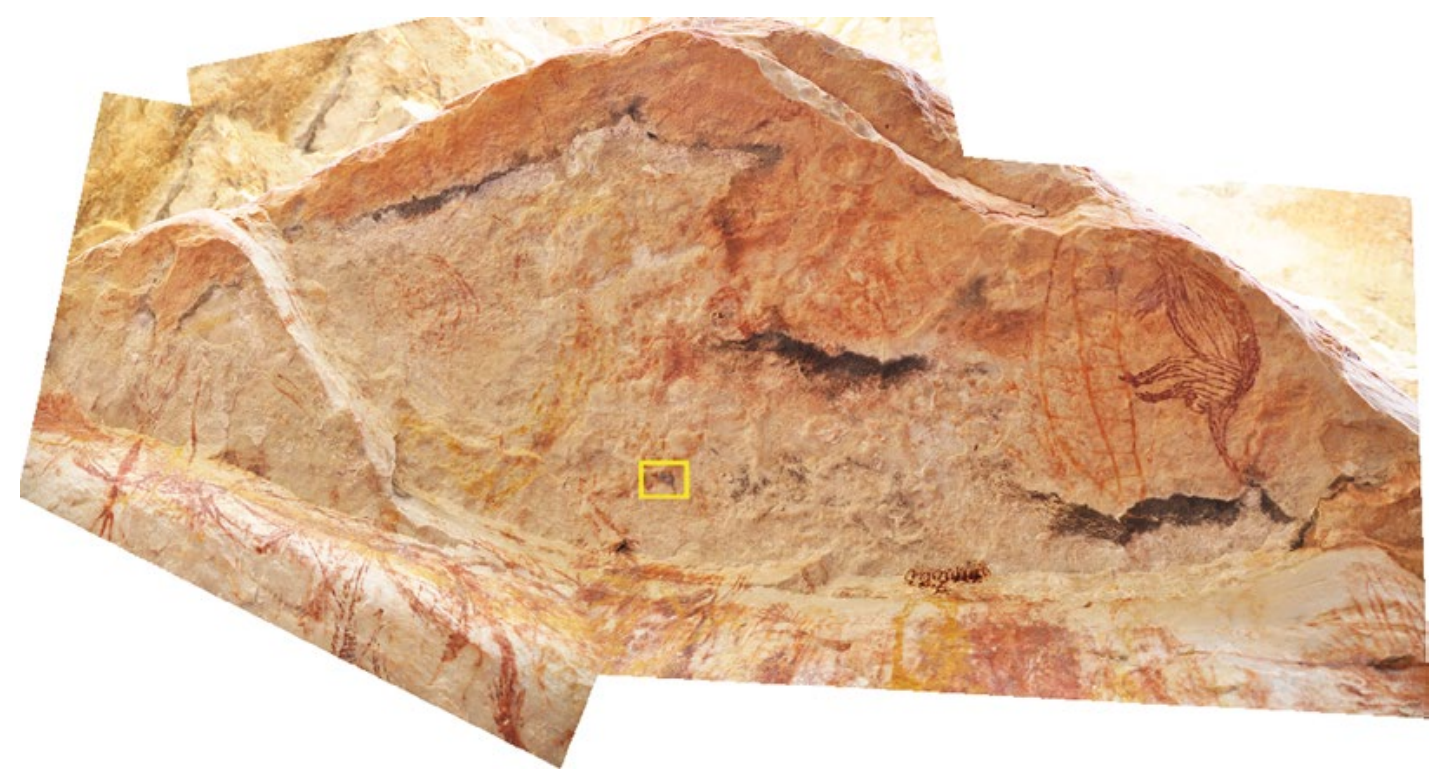

Figure 13.47 Panel C4 panorama showing location of Beeswax Figure 4, yellow rectangle.

Source: Photograph by Daniel James. 


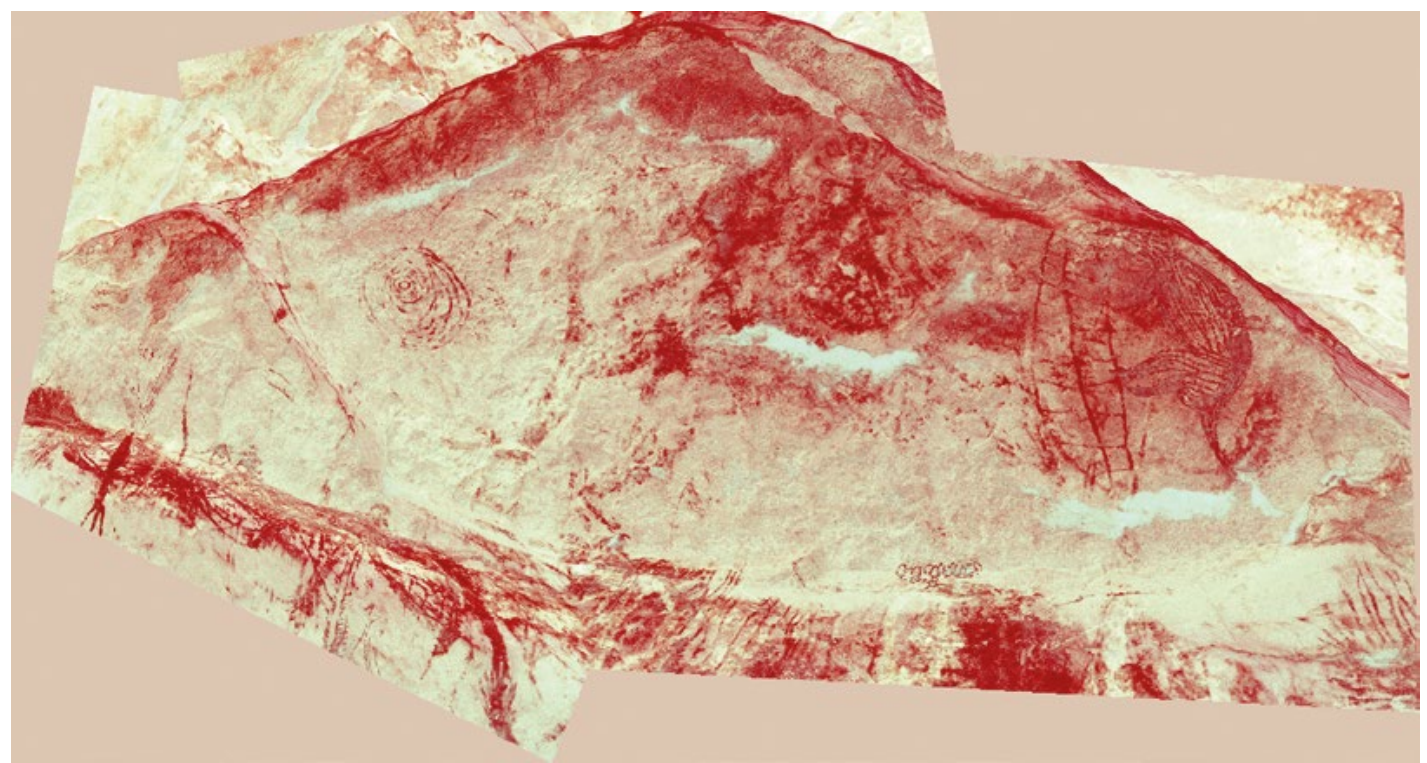

Figure 13.48 Panel C4 panorama of art panel with Beeswax Figure 4, after DStretch_yre10 enhancement.

See Figure 13.47 for location of the beeswax figure.

Source: Photograph and enhancement by Daniel James.

\section{Dalakngalarr 1 summarised}

Two broad depositional phases have been identified for Dalakngalarr 1: Phase 1 begins sometime between 4969-5211 cal BP (Square A) and extends either continuously or intermittently to the period 1186-1281 cal BP (Square B); Phase 2 begins between 0-290 cal BP (Square A) and ends sometime in the early European-contact period. Through a combination of four lines of evidence, we have been able relatively and 'directly' to date art to both depositional phases. Of particular interest is the attribution of forms or 'styles' of X-ray art and use of specific pigment colours to the early European-contact period. All this is consistent with other findings from Jawoyn Country (see Chapters 11 and 12).

\section{Acknowledgements}

This study was undertaken as part of Daniel James' $\mathrm{PhD}$ research in Jawoyn Country, fully supported by Margaret Katherine, senior Traditional Owner of the Buyhmi clan estate, and the Jawoyn Association, Katherine. Our thanks go to Chris Urwin (Monash University) and Britt Wilson for assisting with fieldwork, and Simon Owen who flew us to the site daily. Thanks to Valerie Caron (entomologist, Monash University) for information regarding antlion nymphs, Holly Jones (cultural materials conservator, Monash University) for comments on the metal tools, Steve Morton (Scientific Imaging Services, Monash University) for photographs of metal tools (Figure 13.31) and Monash University School of Medical Imaging and Radiation for Figure 13.32. We thank the Australian Research Council for Linkage grant LP110200927 and Discovery Outstanding Research Award (DORA) Fellowship (to BD) DP130102514, with additional funding provided under the George Chaloupka Fellowship, an initiative of the Museum and Art Gallery of the Northern Territory Foundation, sponsored by Energy Resources of Australia (ERA) Ltd, of which both DJ (2012) and RG (2009) were recipients. 


\section{References}

Allen, H. and G. Barton 1989. Ngarradj Warde Djobkeng: White Cockatoo Dreaming and the Prehistory of Kakadu. Sydney University Press, Sydney.

Chaloupka, G. 1993. Journey in Time: The World's Longest Continuing Art Tradition. Reed, Chatswood.

Dalan, R.A. 2007. A review of the role of magnetic susceptibility in archaeogeophysical studies in the USA: Recent developments and prospects. Archaeological Prospection 15(1):1-31. doi.org/10.1002/ arp.323

Dalan, R.A. and S.K. Banerjee 1998. Solving archaeological problems using techniques of soil magnetism. Geoarchaeology 13:3-36. doi.org/10.1002/(SICI)1520-6548(199801)13:1<3::AIDGEA2 $>3.0 . \mathrm{CO} ; 2-9$

Delannoy, J.-J., B. David, J.-M. Geneste, M. Katherine, B. Barker, R.L. Whear and R.G. Gunn 2013. The social construction of caves and rockshelters: Chauvet Cave (France) and Nawarla Gabarnmang (Australia). Antiquity 87:12-29. doi.org/10.1017/S0003598X00048596

Dubin, L.S. 2006. The History of Beads from 30,000 B.C. to the Present. Thames and Hudson, London.

Ferenczi, P.A. and I.P. Sweet 2004. Mount Evelyn, Northern Territory 1:250 000 Geological Map Series, SE53-05 (Second Edition). Northern Territory Geological Survey, Darwin.

Francis, P. 1991. Some thoughts on the bead trade. The Margaretologist 4(2):3-12.

Francis, P. 1994. Beads of the World. Schiffer Publishing, Atglen.

Gunn, R.G. and R.L. Whear 2007. The Jawoyn Rock Art and Heritage Project. Rock Art Research 24:5-20.

Gunn, R.G., L.C. Douglas and R.L. Whear 2012. Standing stones: An unrecorded form of stone arrangement from the Jawoyn lands of the Arnhem Land plateau. Australian Archaeology 75:37-45. doi.org/10.1080/03122417.2012.11681948

Harris, E. 1987. A Bead Primer. The Bead Museum, Prescott.

Herries, A.I.R. and E.C. Fisher 2010. Multidimensional GIS modeling of magnetic mineralogy as a proxy for fire use and spatial patterning: Evidence from the Middle Stone Age bearing sea cave of Pinnacle Point 13B (Western Cape, South Africa). Journal of Human Evolution 59:306-320. doi.org/10.1016/j.jhevol.2010.07.012

Hodgskiss, T. 2010. Identifying grinding, scoring and rubbing use-wear on experimental ochre pieces. Journal of Archaeological Science 37: 3344-3358. doi.org/10.1016/j.jas.2010.08.003

James, D. in prep. The Painted Past: The Rock-Art of Dalakngalarr 1, Jawoyn Country, Arnhem Land. Unpublished PhD thesis. Monash University, Clayton.

Jones, R. and I. Johnson 1985. Dead Adder Gorge: Lindner Site, Nauwalabila 1. In R. Jones (ed.), Archaeological Research in Kakadu National Park, 165-227. Special Publication 13. Australian National Parks and Wildlife Service, Canberra.

Lane, R., G. Beckitt and M. Duffett 2007. 3D geological mapping and potential field modelling of west Arnhem Land, Northern Territory. ASEG Extended Abstracts 1:1-9. doi.org/10.1071/ ASEG2007ab072

Lewis, D. 1988. The Rock Paintings of Arnhem Land, Australia. BAR International Series 415. British Archaeological Reports, Oxford. 
Lowe, K.M. 2014. Understanding Australia’s Cultural Heritage through Archaeological Geophysics. Unpublished PhD thesis. University of Queensland, St Lucia.

Marwick, B. 2005. Element concentrations and magnetic susceptibility of anthrosols: Indicators of prehistoric human occupation in the inland Pilbara, Western Australia. Journal of Archaeological Science 32:1357-1368. doi.org/10.1016/j.jas.2005.03.009

Morphy, H. 1992. From dull to brilliant: The aesthetics of spiritual power among the Yolngu. In J. Coote and A. Shelton (eds), Anthropology, Art, and Aesthetics, pp. 181-208. Clarendon Press, Oxford.

Reimer, P.J., E. Bard, A. Bayliss, J.W. Beck, P.G. Blackwell, C. Bronk Ramsey, C.E. Buck, H. Cheng, R.L. Edwards, M. Friedrich, P.M. Grootes, T.P. Guilderson, H. Haflidason, I. Hajdas, C. Hatté, T.J. Heaton, D.L. Hoffmann, A.G. Hogg, K.A. Hughen, K.F. Kaiser, B. Kromer, S.W. Manning, M. Niu, R.W. Reimer, D.A. Richards, E.M. Scott, J.R. Southon, R.A. Staff, C.S.M. Turney and J. van der Plicht 2013. IntCal13 and Marine13 radiocarbon age calibration curves, 0-50 000 years cal BP. Radiocarbon 55 (4):1869-1887. doi.org/10.2458/azu_js_rc.55.16947

Rifkin, R. 2012. Processing ochre in the Middle Stone Age: Testing the inference of prehistoric behaviours from actualistically derived experimental data. Journal of Anthropological Archaeology 31:174-195. doi.org/10.1016/j.jaa.2011.11.004

Selwyn, L. 2004. Metals and Corrosion: A Handbook for the Conservation Professional. Canadian Conservation Institute, Ottowa.

Sprague, R. 1985. Glass trade beads: A progress report. Historical Archaeology 19(2):87-105. doi.org/10.1007/BF03373477

Stephens, S.P. 2013. Snapshots of the Holocene: Analysis of Technological Organisation at Little Barra, Jawoyn Country, Western Arnhem Land. Unpublished BA (Hons) thesis, Monash University, Clayton.

Taçon, P. S. C. 1989a. Art and the essence of being: Symbolic and economic aspects of fish among the peoples of western Arnhem Land, Australia. In H. Morphy (ed.), Animals into Art, pp. 236-252. Unwin Hyman, London.

Taçon, P. S. C. 1989b. From Rainbow Snakes to 'X-Ray' Fish: The Nature of the Recent Rock Painting Tradition of Western Arnhem Land, Australia. Unpublished PhD thesis. The Australian National University, Canberra.

Wesley, D. and M. Litster 2015. 'Small, individually nondescript and easily overlooked': Contact beads from northwest Arnhem Land in an Indigenous-Macassan-European hybrid economy. Australian Archaeology 80:1-16. doi.org/10.1080/03122417.2015.11682040

Young, R.W., R.A.L. Wray and A.R.M. Young 2009. Sandstone Landforms. Cambridge University Press, Cambridge. 
This text is taken from The Archaeology of Rock Art in Western Arnhem Land, Australia, edited by Bruno David, Paul Taçon, Jean-Jacques Delannoy and Jean-Michel Geneste, published 2017 by ANU Press, The Australian National University, Canberra, Australia.

dx.doi.org/10.22459/TA47.11.2017.13 